\title{
NTP TECHNICAL REPORT ON THE TOXICITY STUDIES OF \\ SODIUM THIOGLYCOLATE \\ (CASRN 367-51-1) \\ ADMINISTERED DeRMALLY TO \\ F344/N RATS AND \\ B6C3Fl/N MICE
}

NTP TOX 80

MAY 2016 


\title{
NTP Technical Report on the Toxicity Studies of Sodium Thioglycolate (CASRN 367-51-1) Administered Dermally to F344/N Rats and B6C3F1/N Mice
}

Toxicity Report 80

May 2016

\author{
National Toxicology Program \\ Public Health Service \\ U.S. Department of Health and Human Services
}

ISSN: 2378-8992

Research Triangle Park, North Carolina, USA 


\section{Foreword}

The National Toxicology Program (NTP) is an interagency program within the Public Health Service (PHS) of the Department of Health and Human Services (HHS) and is headquartered at the National Institute of Environmental Health Sciences of the National Institutes of Health (NIEHS/NIH). Three agencies contribute resources to the program: NIEHS/NIH, the National Institute for Occupational Safety and Health of the Centers for Disease Control and Prevention (NIOSH/CDC), and the National Center for Toxicological Research of the Food and Drug Administration (NCTR/FDA). Established in 1978, the NTP is charged with coordinating toxicological testing activities, strengthening the science base in toxicology, developing and validating improved testing methods, and providing information about potentially toxic substances to health regulatory and research agencies, scientific and medical communities, and the public.

The Toxicity Study Report series began in 1991. The studies described in the Toxicity Study Report series are designed and conducted to characterize and evaluate the toxicologic potential of selected substances in laboratory animals (usually two species, rats and mice). Substances selected for NTP toxicity studies are chosen primarily on the basis of human exposure, level of production, and chemical structure. The interpretive conclusions presented in the Toxicity Study Reports are based only on the results of these NTP studies. Extrapolation of these results to other species, including characterization of hazards and risks to humans, requires analyses beyond the intent of these reports. Selection per se is not an indicator of a substance's toxic potential.

The NTP conducts its studies in compliance with its laboratory health and safety guidelines and FDA Good Laboratory Practice Regulations and must meet or exceed all applicable federal, state, and local health and safety regulations. Animal care and use are in accordance with the Public Health Service Policy on Humane Care and Use of Animals. Studies are subjected to retrospective quality assurance audits before being presented for public review.

NTP Toxicity Study Reports are indexed in National Center for Biotechnology Information (NCBI) Bookshelf and are available free of charge electronically on the NTP website (http://ntp.niehs.nih.gov). 


\section{Table of Contents}

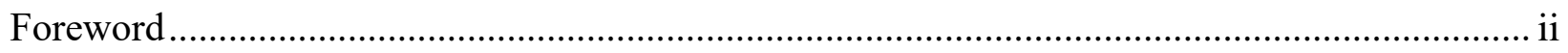

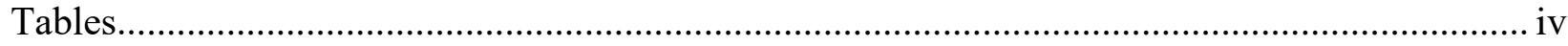

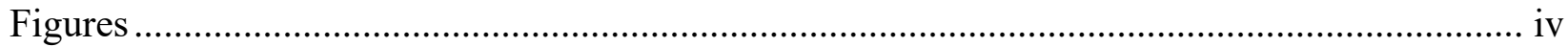

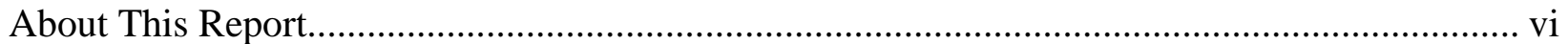

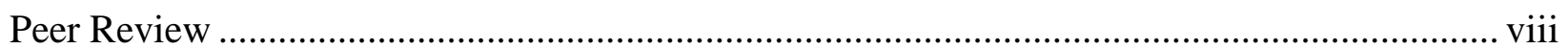

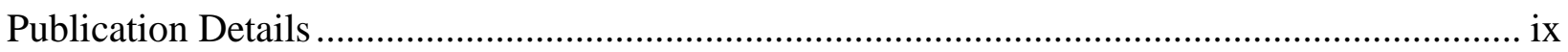

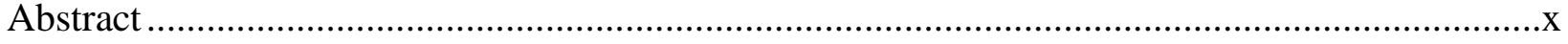

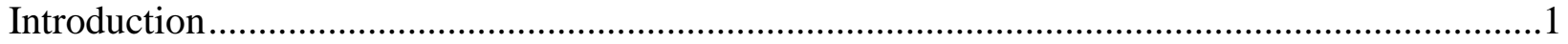

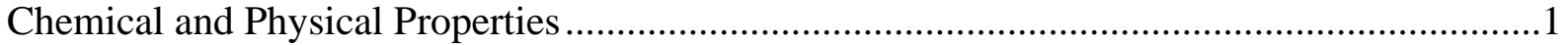

Production, Use, and Human Exposure …………….......................................................

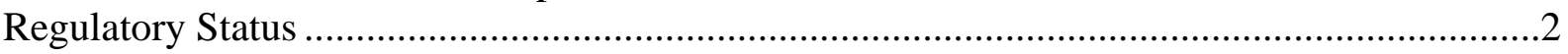

Absorption, Distribution, Metabolism, and Excretion ............................................................

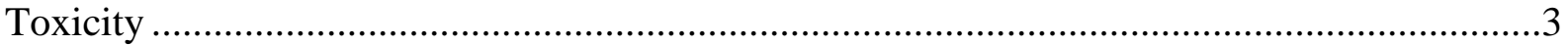

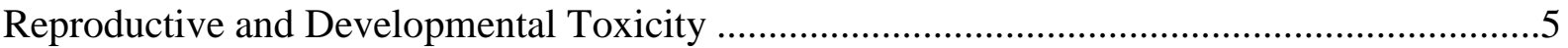

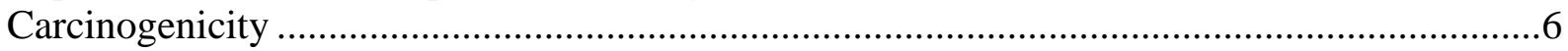

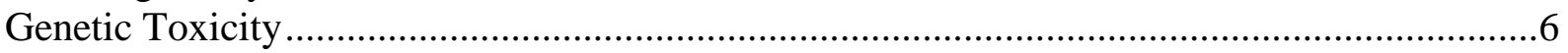

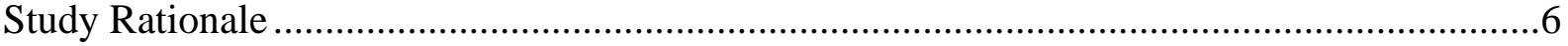

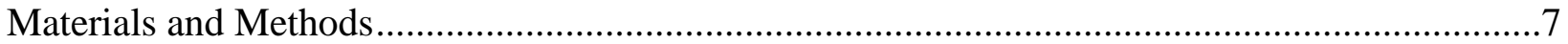

Procurement and Characterization ........................................................................................

Preparation and Analysis of Dose Formulations.................................................................

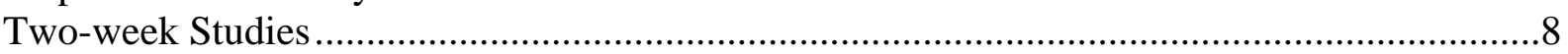

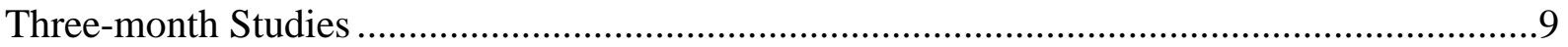

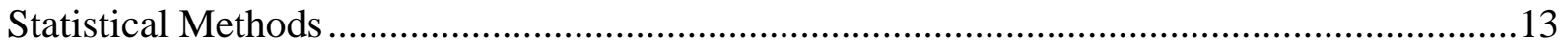

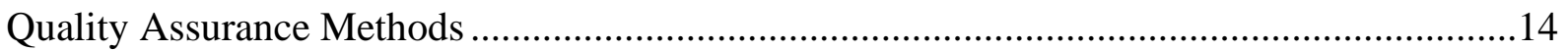

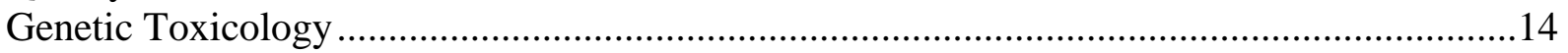

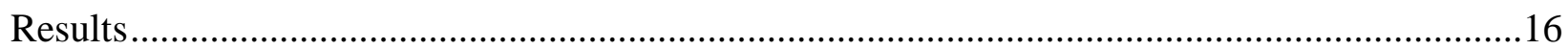

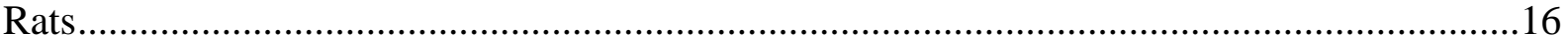

Mice

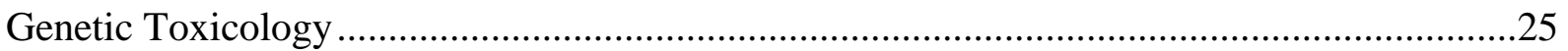

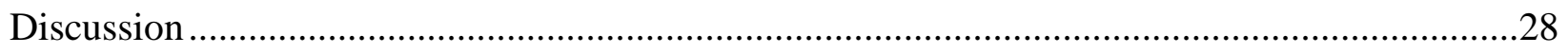

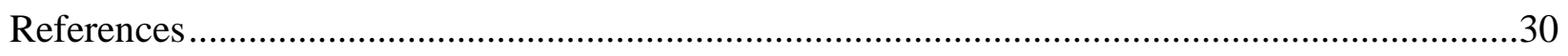

Appendix A. Summary of Neoplasms and Nonneoplastic Lesions in Rats and Mice................ A-1

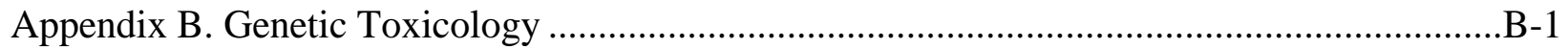

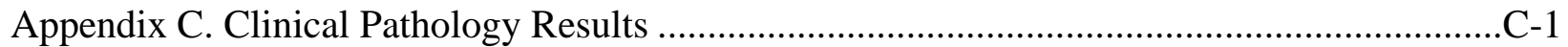

Appendix D. Organ Weights and Organ-Weight-to-Body-Weight Ratios ................................. D-1 
Appendix E. Reproductive Tissue Evaluations and Estrous Cycle Characterization .................. E-1

Appendix F. Chemical Characterization and Dose Formulation Studies .................................F-1

Appendix G. Feed Consumption....................................................................................... G-1

Appendix H. Ingredients, Nutrient Composition, and Contaminant Levels in NTP-2000 Rat and Mouse Ration ..................................................................... H-1

Appendix I. Sentinel Animal Program................................................................................. I-1

\section{Tables}

Table 1. Experimental Design and Materials and Methods in the Dermal Studies of Sodium Thioglycolate

Table 2. Survival and Body Weights of Rats in the Two-week Dermal Study of Sodium Thioglycolate

Table 3. Selected Organ Weights and Organ-Weight-to-Body-Weight Ratios for Male Rats in the Two-week Dermal Study of Sodium Thioglycolate.

Table 4. Survival and Body Weights of Rats in the Three-month Dermal Study of Sodium Thioglycolate

Table 5. Incidences of Nonneoplastic Lesions of the Skin at the Site of Application in Rats in the Three-month Dermal Study of Sodium Thioglycolate

Table 6. Survival and Body Weights of Mice in the Two-week Dermal Study of Sodium Thioglycolate

Table 7. Survival and Body Weights of Mice in the Three-month Dermal Study of Sodium Thioglycolate

Table 8. Selected Organ Weights and Organ-Weight-to-Body-Weight Ratios for Mice in the Three-month Dermal Study of Sodium Thioglycolate.

Table 9. Incidences of Nonneoplastic Lesions of the Skin at the Site of Application in Mice in the Three-month Dermal Study of Sodium Thioglycolate.

\section{Figures}

Figure 1. Sodium Thioglycolate (CASRN 367-51-1; Chemical Formula: $\mathrm{C}_{2} \mathrm{H}_{3} \mathrm{O}_{2} \mathrm{~S} \bullet \mathrm{Na}$; Molecular Weight: 114.10)

Figure 2. Growth Curves for Rats Administered Sodium Thioglycolate Dermally for Three Months

Figure 3. Growth Curves for Mice Administered Sodium Thioglycolate Dermally for Three Months

Figure 4. Normal Aspect of the Skin from a Vehicle Control Male Rat in the Threemonth Dermal Study of Sodium Thioglycolate (H\&E)

Figure 5. Diffuse, Minimal Epidermal Hyperplasia (Thickening) of the Skin of a Male Rat Dermally Administered $180 \mathrm{mg}$ Sodium Thioglycolate/kg Body Weight per Day for Three Months (H\&E) 
Figure 6. Normal Aspect of the Skin from a Vehicle Control Male Mouse in the Three-month Dermal Study of Sodium Thioglycolate (H\&E)

Figure 7. Diffuse, Mild Epidermal Hyperplasia (Thickening) of the Skin of a Male Mouse Dermally Administered $180 \mathrm{mg}$ Sodium Thioglycolate/kg Body Weight per

Day for Three Months (H\&E)

This report has been reformatted to meet new NTP publishing requirements; its content has not changed. 


\section{About This Report}

National Toxicology Program ${ }^{1}$

${ }^{1}$ Division of the National Toxicology Program, National Institute of Environmental Health Sciences, Research Triangle Park, North Carolina, USA

\section{Collaborators}

M. Mercado-Feliciano, M.J. Hooth, A. Nyska, J.B. Bishop, C.R. Blystone, R.S. Chhabra, K.J. Cimon, P.M. Foster, A.P. King-Herbert, G.E. Kissling, L.L. Lanning, D.E. Malarkey, B.S. McIntyre, D.R. Ragland, H. Seung, C.S. Smith, G.S. Travlos, J.C. Turnier, M.K. Vallant, S.

Waidyantha, N.J. Walker, M.L. Wenk, K.L. Witt, G.W. Wolfe

Division of the National Toxicology Program, National Institute of Environmental Health Sciences, Research Triangle Park, North Carolina, USA

Evaluated and interpreted results and reported findings

M. Mercado-Feliciano, Ph.D., Study Scientist

M.J. Hooth, Ph.D., Co-Study Scientist

J.B. Bishop, Ph.D.

C.R. Blystone, M.S., Ph.D.

R.S. Chhabra, Ph.D.

P.M. Foster, Ph.D.

A.P. King-Herbert, D.V.M.

G.E. Kissling, Ph.D.

D.E. Malarkey, D.V.M., Ph.D.

B.S. McIntyre, Ph.D.

C.S. Smith, Ph.D.

G.S. Travlos, D.V.M.

M.K. Vallant, M.T.

S. Waidyantha, Ph.D.

N.J. Walker, Ph.D.

K.L. Witt, M.S.

ILS, Inc., Research Triangle Park, North Carolina, USA

Evaluated and interpreted results and reported findings

A. Nyska, D.V.M., ILS, Inc., Study Pathologist

BioReliance Corporation, Rockville, Maryland, USA

Conducted studies and evaluated pathology findings

M.L. Wenk, Ph.D., Principal Investigator

L.L. Lanning, D.V.M.

D.R. Ragland, D.V.M., M.M.S. 
Experimental Pathology Laboratories, Inc., Research Triangle Park, North Carolina, USA Conducted pathology review

K.J. Cimon, D.V.M., M.S.

Pathology Associates, A Division of Charles River Laboratories, Inc., Research Triangle Park, North Carolina, USA

Coordinated NTP Pathology Working Group (July 1, 2004)

J.C. Turnier, V.M.D.

TherImmune Research Corporation, Gaithersburg, Maryland, USA

Provided SMVCE analysis

H. Seung, M.S.

G.W. Wolfe, Ph.D.

\section{Contributors}

NTP Pathology Working Group, National Institute of Environmental Health Sciences, Research Triangle Park, North Carolina, USA

Participated in NTP Pathology Working Group (July 1, 2004)

A. Nyska, D.V.M., ILS, Inc.

Experimental Pathology Laboratories, Inc., Research Triangle Park, North Carolina, USA Supervised pathology review

M.H. Hamlin, II, D.V.M., Principal Investigator

Dynamac Corporation, Research Triangle Park, North Carolina, USA

Prepared quality assessment audits

S. Brecher, Ph.D., Principal Investigator

S. Iyer, B.S.

V.S. Tharakan, D.V.M.

SRA International, Inc., Research Triangle Park, North Carolina, USA

Provided statistical analyses

R.W. Morris, Ph.D., Principal Investigator

L.J. Betz, M.S.

S.F. Harris, B.S.

Biotechnical Services, Inc., Little Rock, Arkansas, USA

Prepared Toxicity Study Report

S.R. Gunnels, M.A., Principal Investigator

L.M. Harper, B.S.

D.C. Serbus, Ph.D.

G.E. Simmons, M.A. 


\section{Peer Review}

The draft NTP Technical Report on the Toxicity Studies of Sodium Thioglycolate (CASRN 367-51-1) Administered Dermally to F344/N Rats and B6C3F1/N Mice was evaluated by the reviewers listed below. These reviewers served as independent scientists, not as representatives of any institution, company, or governmental agency. In this capacity, reviewers determined if the design and conditions of these NTP studies were appropriate and ensured that this NTP Toxicity Study Report presented the experimental results and conclusions fully and clearly.

\section{Peer Reviewers}

Donna F. Kusewitt, D.V.M., Ph.D.

Department of Molecular Carcinogenesis

University of Texas MD Anderson Cancer Center

Smithville, Texas, USA

Robert H. Rice, Ph.D.

Forensic Graduate Group

University of California, Davis

Davis, California, USA 


\section{Publication Details}

Publisher: National Toxicology Program

Publishing Location: Research Triangle Park, NC

ISSN: 2378-8992

DOI: https://doi.org/10.22427/NTP-TOX-80

Report Series: NTP Toxicity Report Series

Report Series Number: 80

Official citation: National Toxicology Program (NTP). 2016. NTP technical report on the toxicity studies of sodium thioglycolate (CASRN 367-51-1) administered dermally to F344/N rats and B6C3F1/N mice. Research Triangle Park, NC: National Toxicology Program.

Toxicity Report 80. 


\section{Abstract}

Sodium thioglycolate is a white powder with a melting point greater than $300^{\circ} \mathrm{C}$. It appears as hygroscopic crystals with an unpleasant odor characteristic of the sulfhydryl group (mercaptans). Thioglycolic acid can be prepared by the action of sodium sulfhydrate on sodium chloroacetate and by electrolysis of dithioglycollic acid from sodium sulfide and sodium chloroacetate. It is also formed by heating chloroacetic acid with potassium hydrogen sulfide. Thioglycolic acid and its salts and glyceryl esters are not known to occur naturally. Sodium thioglycolate is used in the cosmetic industry as an antioxidant, depilating agent, hair waving/straightening agent, and reducing agent. Its primary cosmetic use is in depilatories. Sodium thioglycolate is also used as an analytical reagent and in bacteriology for the preparation of thioglycolate media. Sodium thioglycolate was nominated by the National Cancer Institute for toxicology studies due to its high production volume and widespread occupational and consumer exposure to thioglycolic acid and its salts and esters, including significant female exposure in personal care products. Male and female $\mathrm{F} 344 / \mathrm{N}$ rats and $\mathrm{B} 6 \mathrm{C} 3 \mathrm{~F} 1 / \mathrm{N}$ mice were administered sodium thioglycolate (approximately 99\% pure) in a vehicle of $95 \%$ ethanol:deionized water (1:1) by application to shaved dorsal skin for 16 (rats) or 17 (mice) days or for 3 months. Genetic toxicology studies were conducted in Salmonella typhimurium and mouse peripheral blood erythrocytes.

In the 2 -week study in rats, groups of five males and five females were dermally administered 0 , $11.25,22.5,45,90$, or $180 \mathrm{mg}$ sodium thioglycolate $/ \mathrm{kg}$ body weight in $95 \%$ ethanol:deionized water (1:1) 5 days per week for 16 days. All rats survived to the end of the study. Mean body weights of dosed groups were similar to those of the vehicle control groups. On day 17, all $180 \mathrm{mg} / \mathrm{kg}$ males, two $90 \mathrm{mg} / \mathrm{kg}$ females, and two $180 \mathrm{mg} / \mathrm{kg}$ females had irritation at the site of application. Kidney and liver weights were significantly increased in $180 \mathrm{mg} / \mathrm{kg}$ males. Lung weights were significantly decreased in all groups of dosed males. Minimal epidermal hyperplasia occurred in male and female rats administered $45 \mathrm{mg} / \mathrm{kg}$ or greater. Mild cytoplasmic focal vacuolization of the centrilobular hepatocytes occurred in all groups of dosed males.

In the 2-week study in mice, groups of five males and five females were dermally administered $0,22.5,45,90,180$, or $360 \mathrm{mg} / \mathrm{kg}$ sodium thioglycolate in $95 \%$ ethanol:deionized water $(1: 1)$ 5 days per week for 17 days. One $360 \mathrm{mg} / \mathrm{kg}$ female was found dead on day 5 . The mean body weight gain of $180 \mathrm{mg} / \mathrm{kg}$ males was significantly greater than that of the vehicle control group. Minimal to mild epidermal hyperplasia occurred in male mice administered $90 \mathrm{mg} / \mathrm{kg}$ or greater and in female mice administered $45 \mathrm{mg} / \mathrm{kg}$ or greater.

In the 3-month study in rats, groups of 10 males and 10 females were dermally administered 0 , $11.25,22.5,45,90$, or $180 \mathrm{mg} / \mathrm{kg}$ sodium thioglycolate in $95 \%$ ethanol:deionized water $(1: 1)$ 5 days per week for 3 months. Additional clinical pathology groups of 10 male and 10 female rats were administered the same doses for 22 days. All rats survived to the end of the study; mean body weights of 90 and $180 \mathrm{mg} / \mathrm{kg}$ males were significantly less than those of the vehicle controls. All sodium thioglycolate dosed rats developed irritation at the site of application. Thickening of the skin in 90 and $180 \mathrm{mg} / \mathrm{kg}$ males and $45 \mathrm{mg} / \mathrm{kg}$ or greater females and ulceration of the skin in 90 and $180 \mathrm{mg} / \mathrm{kg}$ males and females were observed at the site of 
application. Chemical-related nonneoplastic lesions occurred at the site of application and included minimal to mild epidermal hyperplasia, hyperkeratosis, sebaceous gland hypertrophy, and ulcers.

In the 3-month study in mice, groups of 10 males and 10 females were dermally administered 0 , $22.5,45,90,180$, or $360 \mathrm{mg} / \mathrm{kg}$ sodium thioglycolate in $95 \%$ ethanol:deionized water $(1: 1)$ 5 days per week for 3 months. All mice survived to the end of the study; mean body weights of dosed groups were similar to those of the vehicle control groups. Six $360 \mathrm{mg} / \mathrm{kg}$ males developed irritation at the site of application. Heart weights were significantly increased in 180 and $360 \mathrm{mg} / \mathrm{kg}$ males and $360 \mathrm{mg} / \mathrm{kg}$ females. Liver weights were significantly increased in 180 and $360 \mathrm{mg} / \mathrm{kg}$ males and $45 \mathrm{mg} / \mathrm{kg}$ or greater females. Nonneoplastic lesions were limited to the site of application and included minimal to mild epidermal hyperplasia, hyperkeratosis, sebaceous gland hypertrophy, and inflammation.

Sodium thioglycolate was not mutagenic in S. typhimurium strains TA98, TA100, TA1535, or TA1537 when tested with or without liver S9 activation enzymes. Dermal exposure to sodium thioglycolate for 3 months resulted in a small but significant increase in micronucleated normochromatic erythrocytes in peripheral blood of female mice; results in male mice were negative.

In summary, sodium thioglycolate caused minimal to mild nonneoplastic lesions at the site of application in rats and mice after 3 months of exposure through the skin. The no-observed-effect level (NOEL) for site of application lesions in female rats was $11.25 \mathrm{mg} / \mathrm{kg}$. The NOEL for site of application lesions in male mice was $90 \mathrm{mg} / \mathrm{kg}$. There was no NOEL for male rats or female mice.

Synonyms: Mercaptoacetic acid monosodium salt; mercaptoacetic acid, sodium salt; monosodium mercaptoacetate; sodium 2-mercaptoethanoate; sodium mercaptoacetate; sodium thioglycollate; thioglycolate sodium; thioglycolic acid, sodium salt; thioglycollic acid, sodium salt

Trade names: Erhavit D, Mollescal SF 


\section{Introduction}

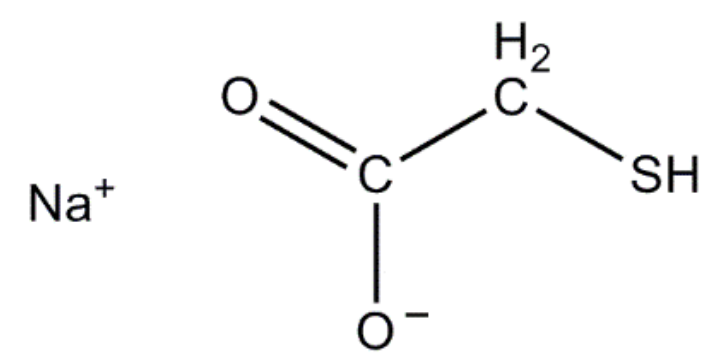

Figure 1. Sodium Thioglycolate (CASRN 367-51-1; Chemical Formula: $\mathrm{C}_{2} \mathrm{H}_{3} \mathrm{O}_{2} \mathrm{~S} \bullet \mathrm{Na}$; Molecular Weight: 114.10)

Synonyms: Mercaptoacetic acid monosodium salt; mercaptoacetic acid, sodium salt; monosodium mercaptoacetate; sodium 2 mercaptoethanoate; sodium mercaptoacetate; sodium thioglycollate; thioglycolate sodium; thioglycolic acid, sodium salt; thioglycollic acid, sodium salt.

Trade names: Erhavit D, Mollescal SF.

\section{Chemical and Physical Properties}

Sodium thioglycolate is a white powder with a melting point greater than $300^{\circ} \mathrm{C}$. It appears as hygroscopic crystals with a characteristic odor. Sodium thioglycolate is soluble in water and slightly soluble in ethanol. It is combustible and discolors on exposure to air or iron ${ }^{1}$.

\section{Production, Use, and Human Exposure}

Sodium thioglycolate is used primarily in the cosmetic industry as an antioxidant, depilating agent, hair waving/straightening agent, and reducing agent. Its primary cosmetic use is in depilatories. Sodium thioglycolate is also used as an analytical reagent and in bacteriology for the preparation of thioglycolate media ${ }^{1-3}$.

The production and use of sodium thioglycolate is linked to the production and use of thioglycolic acid. Thioglycolic acid can be prepared by the action of sodium sulfhydrate on sodium chloroacetate and by electrolysis of dithioglycollic acid from sodium sulfide and sodium chloroacetate $^{4}$. It is also formed by heating chloroacetic acid with potassium hydrogen sulfide ${ }^{1}$. Thioglycolic acid and its salts and glyceryl esters are not known to occur naturally. No information was found in the literature identifying these chemicals in environmental media.

The annual United States production of thioglycolic acid was reported to be in the range of 10 to 50 million pounds for 2005; the most recent production numbers available for the sodium salt (10 to 500,000 pounds) are from $1994^{5}$. While most of the volume of thioglycolic acid is used for industrial applications, the acid and its salts and glyceryl esters, including sodium thioglycolate, are used in cosmetic hair care products. Thioglycolates reduce the cystine disulfide linkages in the hair cortex, thereby weakening the keratin molecule. The predominant use of thioglycolic acid, ammonium thioglycolate, and glyceryl thioglycolate is in permanent wave and hair straightening products. Thioglycolic acid and ammonium thioglycolate concentrations in these products range from $7 \%$ to $19 \%$, while glyceryl thioglycolate concentrations of $20 \%$ have been reported $^{6}$. Permanent wave products containing ammonium thioglycolate that are applied to the hair without heat may be expected to remain on the hair and scalp for as long as 10 to 
40 minutes; products applied with heat usually contain thioglycolates other than the ammonium salt and are generally processed in 30 minutes but may remain on the head for up to 1 hour ${ }^{6}$. Hair straightening products containing ammonium or ethanolamine thioglycolate or thioglycolic acid are usually applied to the hair for 45 minutes. Thioglycolic acid and its sodium and calcium salts are also used as depilatories. The concentrations of thioglycolic acid and calcium thioglycolate in depilatories are reported to be $2 \%$ to $5 \%$ and $5 \%$ to $7 \%$, respectively $6 ; 7$. The sodium thioglycolate concentration in depilatories has been reported as $4 \%$. Depilatory products containing thioglycolic acid and/or its salts are commonly applied to the face, legs, and arms, usually for a recommended maximum of 10 minutes, and may come in contact with the scalp and ocular and nasal mucosa.

The National Occupational Exposure Survey (NOES) conducted by the National Institute of Occupational Safety and Health (NIOSH) ${ }^{8}$ between 1981 and 1983 estimated that 30,055 workers were potentially exposed to thioglycolic acid in the workplace, that 41,132 workers were potentially exposed to ammonium thioglycolate in the workplace, and that 7,553 workers were potentially exposed to sodium thioglycolate in the workplace. The NOES database does not contain information on the frequency, level, or duration of exposure to workers of any chemical listed therein. Occupational exposure may be through inhalation of aerosols and dermal contact with these compounds at workplaces where they are produced or used. The general population may be exposed to these compounds by similar routes of exposure through the use of hair care products $^{7}$.

\section{Regulatory Status}

The American Conference of Governmental Industrial Hygienists (ACGIH) ${ }^{9}$ recommended a threshold limit value-time weighted average for thioglycolic acid of $1 \mathrm{ppm}\left(3.8 \mathrm{mg} / \mathrm{m}^{3}\right)$ with a skin notation to minimize the potential for dermal effects, eye irritation, and systemic effects. No short-term exposure limit (STEL) is recommended until additional toxicological data and industrial hygiene experience become available to determine what the STEL should be. The recommended exposure limit for thioglycolic acid is $1 \mathrm{ppm}\left(4 \mathrm{mg} / \mathrm{m}^{3}\right)$, with a skin notation, averaged over a 10-hour work shift ${ }^{10}$.

\section{Absorption, Distribution, Metabolism, and Excretion}

\section{Experimental Animals}

Freeman et al. ${ }^{11}$ investigated the dermal absorption of ${ }^{35} \mathrm{~S}$-sodium thioglycolate using male rabbits (strain not specified). A $25.0 \%$ solution of ${ }^{35} \mathrm{~S}$-thioglycolic acid $(330 \mathrm{mg} / \mathrm{kg}$ ) was applied to the dorsal skin. After 1 hour, $5 \%$ to $8 \%$ of the applied dose was excreted (measured as sulfur excretion), indicating rapid absorption from the skin. After 5 hours, $30 \%$ to $40 \%$ of the applied dose was excreted in the urine. Additional male rabbits receiving a dermal application of $660 \mathrm{mg} / \mathrm{kg}$ excreted $7 \%$ to $24 \%$ of the applied dose in 4 hours. Although it appears that no more thioglycolate was absorbed and excreted when the higher dose was applied, rabbits receiving $600 \mathrm{mg} / \mathrm{kg}$ died within 24 hours. After intravenous injection of 70, 80, or $123 \mathrm{mg} / \mathrm{kg}$ to rabbits, $60 \%$ to $80 \%$ of the doses were excreted in the urine within 24 hours $^{11}$. The test substance was excreted mostly as organic sulfate and neutral sulfur. The distribution and excretion of ${ }^{35} \mathrm{~S}-$ thioglycolic acid were evaluated in adult male New Zealand rabbits given 100 or $200 \mathrm{mg} / \mathrm{kg}$ doses of ${ }^{35} \mathrm{~S}$-thioglycolic acid by intraperitoneal injection ${ }^{12}$. After 24 hours, $84 \%$ to $93 \%$ of the 
administered doses were excreted in the urine, and most of the radioactivity appeared in the neutral sulfate fraction. A single topical application of sodium ${ }^{35}$ S-thioglycolate in Triton ${ }^{\circledR} \mathrm{X}-200$ $(1.0 \mathrm{~mL} / \mathrm{kg})$ to rabbits resulted in $16 \%$ of the radiolabel excreted after 24 hours, $4.5 \%$ after 48 hours, and $1.84 \%$ after 72 hours ${ }^{13}$. After 4 days of topical administration, 24-hour urinary radioactivity peaked on day 4 , with measurable radioactivity still detected on day 7 . A single rabbit received sodium ${ }^{35} \mathrm{~S}$-thioglycolate in Triton ${ }^{\circledR} \mathrm{X}-200$ at $2.0 \mathrm{~mL} / \mathrm{kg}$ per day for 7 days. The initial 24 -hour urinary ${ }^{35} \mathrm{~S}$ recovery was $18.5 \%$ of the dose, with recovery falling to $4.7 \%$ by the seventh application. The animal died the next day.

Rats administered ${ }^{35} \mathrm{~S}$-sodium thioglycolate intraperitoneally at doses of 12.5 to $75 \mathrm{mg} / \mathrm{kg}$ excreted $60 \%$ to $100 \%$ of the dose within 24 hours; $29 \%$ to $72 \%$ of the administered dose was excreted as inorganic sulfate ${ }^{11}$. The pulmonary excretion of hydrogen disulfide was not noted up to 10 hours after intraperitoneal injection of a rat with $150 \mathrm{mg} / \mathrm{kg}$ of sodium thioglycolate ${ }^{11}$. In a similar study where Holtzman rats were administered $100 \mathrm{mg} / \mathrm{kg}{ }^{35} \mathrm{~S}$-thioglycolic acid via intravenous or intraperitoneal injection, similar to rabbits, $82 \%$ or $91 \%$ of the administered dose was excreted in urine 24 hours after administration ${ }^{12}$. In an animal injected intravenously with $50 \mathrm{mg} / \mathrm{kg}{ }^{35} \mathrm{~S}$-thioglycolic acid, the highest radioactivity 2 hours postinjection was observed in small intestine and kidneys. Following injection of $100 \mathrm{mg} / \mathrm{kg}$, the rate of disappearance of radioactivity in blood was rapid with less than $3 \%$ radioactivity left 1 hour postinjection. In a subsequent study, 100 to $150 \mathrm{mg}$ thioglycolic acid/kg administered intraperitoneally to rats led to significant urinary excretion of dithioglycolic acid (average of $28 \%$ of the dose) at 24 hours postinjection. Only negligible concentrations of thioglycolate were detected, suggesting the oxidation of thiols to disulfides.

The distribution of radioactivity in a female monkey was determined after intravenous injection of $300 \mathrm{mg} / \mathrm{kg}^{35} \mathrm{~S}$-sodium thioglycolate ${ }^{11}$. The greatest amount of radioactivity was found in the kidney, lung, and spleen 10 hours after injection, at which time the animal died. The monkey excreted thioglycolate mostly in the neutral sulfur fraction.

\section{Humans}

No data on the absorption, distribution, metabolism, or excretion of sodium thioglycolate in humans were found in the literature.

\section{Toxicity}

\section{Experimental Animals}

Exposure to sodium thioglycolate through oral dosing, intraperitoneal injection, or intravenous injection has been shown to result in convulsion, dyspnea, and death in studies using mice, rats, monkeys, and $\operatorname{dog} s^{14}$. The oral $\mathrm{LD}_{50}$ for sodium thioglycolate in fasted female $\mathrm{CAF}_{1}$ mice was reported to be $504 \mathrm{mg} / \mathrm{kg}^{14}$. The intraperitoneal $\mathrm{LD}_{50}$ was $505 \mathrm{mg} / \mathrm{kg}$ for fasted female $\mathrm{CAF}_{1}$ mice ${ }^{14}, 200$ to $300 \mathrm{mg} / \mathrm{kg}$ for $\mathrm{CF}_{1} \mathrm{mice}^{15}$, and $126 \mathrm{mg} / \mathrm{kg}$ for young adult, fasted male OsborneMendel rats ${ }^{14}$. The intravenous $\mathrm{LD}_{50}$ was $422 \mathrm{mg} / \mathrm{kg}$ for mice ${ }^{16}$. The lowest lethal dose after intravenous injection was $100 \mathrm{mg} / \mathrm{kg}$ in rabbits ${ }^{16}, 500 \mathrm{mg} / \mathrm{kg}$ in dogs ${ }^{14}$, and $300 \mathrm{mg} / \mathrm{kg}$ in a female monkey ${ }^{14}$. Sodium thioglycolate resulted in tremor, hypermotility, diarrhea, emesis, and convulsions in the dogs and emesis and coma in the monkey ${ }^{14}$. 
Topical administration of sodium thioglycolate to rabbits at $0.600 \mathrm{~N}$ thioglycolate $(\mathrm{pH} 9.31)$ in $4 \%$ Triton ${ }^{\circledR} \mathrm{X}-200$ at 2.0 to $2.5 \mathrm{mg} / \mathrm{mL}$ resulted in an $\mathrm{LD}_{50}$ of $1.69 \pm 0.11 \mathrm{~mL} / \mathrm{kg}$ per day, with an average of eight applications prior to death ${ }^{13}$.

Five male weanling Osborne-Mendel rats were injected intraperitoneally for 5 days a week with sodium thioglycolate at doses of $25,50,75,100$, or $125 \mathrm{mg} / \mathrm{kg}$ for 12 weeks ${ }^{14}$. The rats in the higher dose groups exhibited lacrimation, apparent increased peristalsis of the gastrointestinal tract followed by a period of intermittent convulsions, and then dyspnea and death with convulsions.

Sodium thioglycolate was administered intraperitoneally (100 mg/kg as a $5 \%$ solution) to five male weanling Osborne-Mendel rats that were either in a "non-diabetic" or chemically induced "diabetic" state ${ }^{14}$. Injections were given 5 days per week during a 24-week period. At the end of the 24-week period, there was no significant difference in weight gain between the treated and control groups. No significant gross lesions were observed at necropsy.

Sodium thioglycolate blocks fatty acid oxidation at different levels in the metabolic pathway and stimulates feed consumption in rats and mice when fed a fat-supplemented $\operatorname{diet}^{17}$. Male Sprague Dawley rats exhibited three to fourfold higher feed consumption when given a medium-fat diet (18\% fat) after an intraperitoneal injection of $46 \mathrm{mg} / \mathrm{kg}(400 \mu \mathrm{mol} / \mathrm{kg})$ sodium thioglycolate ${ }^{18}$. Another study reported that rats maintained on low-, medium-, or high-fat diets $(4.3 \%, 13.5 \%$, or $66.4 \%$, respectively) ate significantly more feed after a single intraperitoneal dose of $69 \mathrm{mg} / \mathrm{kg}$ $(600 \mu \mathrm{mol} / \mathrm{kg})$ sodium thioglycolate ${ }^{19}$. In another study, increases in feed consumption were observed in rats on medium (18\%) but not low-fat (3.3\%) diets ${ }^{20} ; 6$ hours after injection, plasma free fatty acid concentrations were threefold greater and plasma 3-hydroxybutyrate and acetoacetate concentrations were significantly decreased in rats on a medium-fat diet compared to controls, indicating that fatty acid oxidation was inhibited. A robust summary of an unpublished oral gavage subchronic study in Sprague Dawley rats also reports increased feed consumption, increased fatty acids, and decreased 3-hydroxybutyrate and glucose in plasma, as well as increased alanine aminotransferase and urea in plasma and an increased incidence of minimal to slight periportal hepatocellular microvacuolation ${ }^{21}$.

Six hours after an intravenous injection of $175 \mathrm{mg}$ sodium thioglycolate/kg to rabbits, blood sugar concentrations dropped to $55 \%$ of their initial value ${ }^{14}$. In rats, this decrease was $65 \%$ compared to controls and occurred 5 to 6 hours after an intraperitoneal injection of $150 \mathrm{mg} / \mathrm{kg}$. Mice administered $630 \mathrm{mg} / \mathrm{kg}$ intraperitoneally had a $70 \%$ decrease in hepatic glycogen concentrations.

\section{Humans}

Exposure to ammonium thioglycolate and glyceryl thioglycolate has been shown to result in skin irritation and sensitization ${ }^{15}$. The irritant capacity of ammonium thioglycolate solutions depends on concentration of the reagent (greater than 7\%), duration of exposure, and formulation/basicity of the solution; for example, cold wave formulations are more irritating. Single applications of $6.5 \%$ or $7.0 \%$ ammonium thioglycolate and repeated applications of $6.5 \%$ ammonium thioglycolate (applied daily for 40 to 60 minutes over a period of 2 months) did not induce skin irritation in normal subjects. However, repeated applications (24 hours daily for 21 days) of permanent wave solutions containing $7.1 \%$ ammonium thioglycolate, $5.0 \%$ urea, and $1.2 \%$ 
ammonium hydroxide caused strong skin irritation reactions in normal subjects. Ammonium thioglycolate $(6.0 \%)$ was classified as a skin irritant and sensitizer after single applications were made to subjects with a history of dermatitis, cutaneous disturbances, and/or a history of use of cold wave formulations, such as hairdressers. The sensitizing activity of ammonium thioglycolate is much lower in normal subjects, who display weak sensitization reactions with repeated exposures to greater concentrations of the reagent.

The irritant capacity of glyceryl thioglycolate solutions is greater than that of ammonium thioglycolate solutions. A 21-day dermal study of a $2.0 \%$ aqueous solution of glyceryl thioglycolate induced skin irritation in all subjects tested ${ }^{15}$. A challenge application 10 days after completion of the test induced an allergic response in some of these subjects. However, glyceryl thioglycolate was not an irritant at concentrations of $14.0 \%$ to $15.4 \%$ in normal subjects who received two 48-hour patch applications separated by a 14-day nontreatment period. Skin sensitization and allergic contact dermatitis were widely observed in hairdressers and clients who received single applications of $0.25 \%$ to $2.5 \%$ glyceryl thioglycolate in a 48 -hour patch test.

A safety assessment by the Cosmetic Ingredient Review ${ }^{6}$ of thioglycolic acid, sodium thioglycolate, and other thioglycolic acid derivatives concluded that without adequate skin protection, hairdressers should avoid repeated applications of cosmetic products containing ammonium or glyceryl thioglycolate to multiple clients over a period of time. In addition, the Cosmetic, Toiletry, and Fragrance Association (CTFA) ${ }^{2}$ concluded that hairdressers should avoid skin contact and minimize consumer skin exposure to these compounds.

\section{Reproductive and Developmental Toxicity}

Animal studies evaluating developmental effects of thioglycolate exposure are limited. The National Toxicology Program completed developmental toxicity studies for sodium thioglycolate using Sprague Dawley rats and New Zealand White rabbits ${ }^{22}$. Sodium thioglycolate was administered by unoccluded topical application to pregnant Sprague Dawley rats (25 per group) at doses of $0,50,100$, or $200 \mathrm{mg} / \mathrm{kg}$ per day on gestation day (GD) 6 to 19 . One of 20 pregnant $200 \mathrm{mg} / \mathrm{kg}$ rats died on GD 18. Dams dosed with $200 \mathrm{mg} / \mathrm{kg}$ had decreased body weights and weight gain and increased relative water consumption. Treatment-related increases in feed consumption and changes at the application site occurred at all doses in the absence of increased body weights or body weight change. Male and female fetal body weights per litter were also decreased at $200 \mathrm{mg} / \mathrm{kg}$. New Zealand White rabbits ( 24 per group) were dosed dermally with sodium thioglycolate at doses of $0,10,15,25$, or $65 \mathrm{mg} / \mathrm{kg}$ per day on GD 6 to 29. Maternal toxicity at the site of application (erythema) was observed in all dosed groups. Maternal and fetal body weights were not affected. Sodium thioglycolate did not affect resorptions, fetal viability, or fetal external, visceral, or skeletal alterations in either species.

A dose range-finding embryo-fetal toxicity study of ammonium thioglycolate was carried out in Wistar rats (Walker ${ }^{23 ; 24}$ cited in Tyl et al. ${ }^{22}$ ). The test chemical was administered by oral gavage once daily on GD 6 through 19 at doses of $0,1,10,50,100$, or $150 \mathrm{mg} / \mathrm{kg}$ per day to five spermpositive females per group. All five $150 \mathrm{mg} / \mathrm{kg}$ females died, and three of five $100 \mathrm{mg} / \mathrm{kg}$ females died. Body weight gain was decreased from GD 6 through 10 in females dosed with 50, 100 , or $150 \mathrm{mg} / \mathrm{kg}$ per day. Fetal loss was increased in the two surviving $100 \mathrm{mg} / \mathrm{kg}$ dams. Based on this range-finding study, a definitive developmental toxicity study of ammonium thioglycolate was carried out in Wistar rats $\left(W^{2} k_{k e r}{ }^{23} 24\right.$ cited in Tyl et al. ${ }^{22}$ ). Ammonium 
thioglycolate was administered by oral gavage at doses of $0,3,15$, or $75 \mathrm{mg} / \mathrm{kg}$ per day to 25 sperm-positive females per group on GD 6 through 19. Two $75 \mathrm{mg} / \mathrm{kg}$ dams died on GD 20. Maternal body weights and feed and water consumption were unaffected by treatment. The number of ovarian corpora lutea, uterine implantations, early and late resorptions, dead fetuses, live fetuses per litter, sex distribution, fetal body weights, and frequency of fetal malformations per litter were all unaffected by treatment.

No reproductive toxicity studies of sodium thioglycolate in animals were found in the literature.

\section{Carcinogenicity}

\section{Experimental Animals}

There was no evidence of carcinogenicity in female Swiss mice or female rabbits (strain not specified) that received dermal applications of $0.02 \mathrm{~mL}$ of $1 \%$ or $2 \%$ sodium thioglycolate solutions in acetone twice per week when compared to control groups ${ }^{25}$. Sodium thioglycolate was applied to the shaved interscapular skin of 45 to 49 mice and to the inside of the left ear of five rabbits. Mice were allowed to die spontaneously or were killed when moribund, and rabbits were killed at week 85. Incidences of neoplasms in dosed and control mice were not significantly different. No neoplasms were observed in rabbits treated with sodium thioglycolate. No significant change was observed in the survival of dosed mice or rabbits.

\section{Humans}

No epidemiology studies of thioglycolic acid, its ammonium, calcium, or sodium salts, or its glyceryl esters were found in the literature.

\section{Genetic Toxicity}

Sodium thioglycolate was not mutagenic at concentrations up to 3,600 $\mu \mathrm{g} / \mathrm{plate}$ in Salmonella typhimurium strains TA98, TA100, TA1535, TA1537, or TA1538, with or without rat or hamster liver S9 metabolic activation enzymes ${ }^{26 ; 27}$. No increases were reported in the frequencies of micronucleated erythrocytes in bone marrow of male or female NMRI mice administered 114 or $285 \mathrm{mg}$ sodium thioglycolate $/ \mathrm{kg}$ intraperitoneally ${ }^{26}$. However, the lack of experimental detail makes it difficult to determine whether the test protocol was adequate to detect the in vivo mutagenic potential of sodium thioglycolate. Sodium thioglycolate administered by feeding in $5 \%$ sucrose was tested for induction of sex-linked recessive lethal mutations in germ cells of male Drosophila melanogaster; results were negative ${ }^{15 ; 26}$.

\section{Study Rationale}

Sodium thioglycolate was nominated by the National Cancer Institute for toxicology studies due to its high production volume and widespread occupational and consumer exposure to thioglycolic acid and its salts and esters, including significant female exposure in personal care products. 


\section{Materials and Methods}

\section{Procurement and Characterization}

\section{Sodium Thioglycolate}

Sodium thioglycolate was obtained by the analytical chemistry laboratory (Midwest Research Institute, Kansas City, MO) from Sigma Chemical Company (Columbus, OH) in one lot (88H1166) that was used in the 2-week and 3-month studies. Identity, purity, and stability analyses were conducted by the analytical chemistry laboratory (Appendix F). Reports on analyses performed in support of the sodium thioglycolate studies are on file at the National Institute of Environmental Health Sciences.

The chemical, a white powder, was identified as sodium thioglycolate by infrared and proton and carbon-13 nuclear magnetic resonance spectroscopy. The purity of lot 88H1166 was determined by ion chromatography. Purity assays indicated one major peak and three impurities with a combined area of approximately $1 \%$ relative to the total peak area. The overall purity of lot $88 \mathrm{H} 1166$ was determined to be approximately $99 \%$.

Stability studies of a different lot of the bulk chemical were performed by the analytical chemistry laboratory using ion chromatography. These studies indicated that sodium thioglycolate was stable as a bulk chemical for 14 days when stored protected from light frozen $\left(-20^{\circ} \mathrm{C}\right)$, refrigerated $\left(5^{\circ} \mathrm{C}\right)$, and heated $\left(60^{\circ} \mathrm{C}\right)$ but not at ambient $\left(25^{\circ} \mathrm{C}\right)$ temperature. To ensure stability, the bulk chemical was stored under a headspace of inert gas at less than or equal to $-20^{\circ} \mathrm{C}$, protected from light, in amber glass bottles. The analytical chemistry laboratory reanalyzed the bulk chemical at the end of the 3-month study by ion chromatography. No degradation of the bulk chemical was detected.

\section{5\% Ethanol}

95\% Ethanol, a clear liquid, was obtained from Pharmco Products, Inc. (Brookfield, CT), in two lots (P1107 and R8092); lot P1107 was used in the 2-week studies, and lot R8092 was used in the 3-month studies. The study laboratory (BioReliance Corporation, Rockville, MD) identified lot R8092 of the chemical as ethanol by infrared spectroscopy and determined the purities of both lots of the chemical using gas chromatography; no impurity peaks were noted.

\section{Preparation and Analysis of Dose Formulations}

The dose formulations were prepared on three separate days during the 2-week studies and approximately weekly during the 3-month studies by mixing sodium thioglycolate and the vehicle [95\% ethanol:deionized water (1:1)] to give the required concentration. The dose formulations were stored under an inert gas headspace at $2^{\circ}$ to $8^{\circ} \mathrm{C}$ in amber vials sealed with Teflon ${ }^{\circledR}$-lined septa and aluminum seals for up to 10 days. Fresh dosing bottles were used each day.

Stability studies of a $3.1 \mathrm{mg} / \mathrm{mL}$ dose formulation of a different lot were performed by the analytical chemistry laboratory using ion chromatography. Stability was confirmed for at least 
10 days for dose formulations stored at approximately $5^{\circ} \mathrm{C}$ in sealed amber vials and for at least 3 hours for dose formulations exposed to ambient temperature and light.

Periodic analyses of samples of the dose formulations of sodium thioglycolate were conducted by the analytical chemistry laboratory because ion chromatography was not available at the study laboratory. Samples of formulations were collected in amber glass vials under inert gas headspace and shipped on dry ice for overnight delivery to the analytical chemistry laboratory. Animal room samples were collected similarly following dosing on the last day of the use period. During the 2-week studies, the dose formulations were analyzed twice; nine of 10 dose formulations for rats and eight of 10 dose formulations for mice were within $10 \%$ of the target concentrations. For animal room samples analyzed, three of five for rats and three of five for mice were within $10 \%$ of the target concentrations. During the 3-month studies, the dose formulations were analyzed at the beginning, midpoint, and end of the studies; animal room samples of these dose formulations were also analyzed. Of the dose formulations analyzed, all 15 for rats and all 15 for mice were within $10 \%$ of the target concentrations; two of 15 animal room samples analyzed for rats and four of 15 animal room samples analyzed for mice were within $10 \%$ of the target concentrations.

\section{Two-week Studies}

Two-week studies were conducted to evaluate the cumulative toxic effects of repeated applications of sodium thioglycolate and to determine the appropriate doses to be used in the 3-month studies. The highest dose concentration for the 2-week rat study was limited by the maximum solubility of sodium thioglycolate in the test vehicle. The maximum concentration determined for the test article solubility was $364 \mathrm{mg}$ sodium thioglycolate per $\mathrm{mL}$ of $95 \%$ ethanol:deionized water. Therefore, the highest dose selected for rats was $180 \mathrm{mg} / \mathrm{kg}(0.5 \mathrm{~mL} / \mathrm{kg}$ dosing volume). For the 2-week mouse study, the highest dose possible based on the solubility of sodium thioglycolate would have exceeded the $\mathrm{LD}_{50}$ values in the literature $(2.0 \mathrm{~mL} / \mathrm{kg}$ dosing volume $=720 \mathrm{mg} / \mathrm{kg}$ ). Therefore, the highest dose selected for mice was $360 \mathrm{mg} / \mathrm{kg}$, which is approximately half the highest concentration possible based on solubility.

Male and female F344/N rats and B6C3F1/N mice were obtained from Taconic Farms, Inc. (Germantown, NY). On receipt, the rats and mice were approximately 4 weeks old. Animals were quarantined for 12 days and were 6 weeks old on the first day of the studies. Groups of five male and five female rats and mice received dermal applications of sodium thioglycolate in a vehicle of $95 \%$ ethanol:deionized water $(1: 1)$ at doses of $11.25,22.5,45,90$, or $180 \mathrm{mg} / \mathrm{kg}$ body weight (rats) or $22.5,45,90,180$, or $360 \mathrm{mg} / \mathrm{kg}$ (mice) 5 days per week for 16 (rats) or 17 (mice) days. Control animals were administered the vehicle only. Feed and water were available ad libitum. Rats and mice were housed individually. Clinical findings were recorded daily for rats and mice. The animals were weighed initially, on day 8 , and at the end of the studies. Before the studies began, five male and five female rats and mice were randomly selected for parasite evaluation and gross observation for evidence of disease. All test results were negative. Details of the study design and animal maintenance are summarized in Table 1.

Necropsies were performed on all rats and mice. The heart, right kidney, liver, lung, spleen, right testis, thymus, and thyroid gland were weighed. Histopathologic examinations were performed on vehicle control rats and mice, $180 \mathrm{mg} / \mathrm{kg}$ rats, $360 \mathrm{mg} / \mathrm{kg}$ mice, and animals that died early. Table 1 lists the tissues and organs examined to a no-effect level. 


\section{Three-month Studies}

Male and female $\mathrm{F} 344 / \mathrm{N}$ rats and B6C3F1/N mice were obtained from Taconic Farms, Inc. (Germantown, NY). On receipt, the rats were 4 weeks old and the mice were 3 weeks old. Rats were quarantined for 13 (males) or 14 (females) days and were 6 weeks old on the first day of the studies. Mice were quarantined for 16 (males) or 17 (females) days and were 6 weeks old on the first day of the studies. Before the studies began, five male and five female rats and mice were randomly selected for parasite evaluation and gross observation for evidence of disease. At the end of the studies, serologic analyses were performed on five male and five female vehicle control rats and sentinel mice using the protocols of the NTP Sentinel Animal Program (Appendix I). All test results were negative.

Groups of 10 male and 10 female core study rats and mice received dermal applications of sodium thioglycolate in a vehicle of $95 \%$ ethanol:deionized water (1:1) at doses of 11.25 (rats only), 22.5, 45, 90, 180, or 360 (mice only) $\mathrm{mg} / \mathrm{kg}$ body weight 5 days per week for 3 months; the dosing volume was $0.5 \mathrm{~mL} / \mathrm{kg}$ for rats and $2.0 \mathrm{~mL} / \mathrm{kg}$ for mice. Additional groups of 10 male and 10 female rats designated for clinical pathology testing were administered the same doses for up to 22 days. Vehicle control rats and mice were administered the vehicle only. Doses were applied to the shaved dorsal skin from just posterior to the scapulae to the base of the tail. The dosing area was shaved weekly in both rats and mice. Feed and water were available ad libitum. Rats and mice were housed individually. All animal studies were conducted in an animal facility accredited by the Association for the Assessment and Accreditation of Laboratory Animal Care International. Studies were approved by the BioReliance Corporation (Rockville, MD) Animal Care and Use Committee and conducted in accordance with all relevant NTP animal care and use policies and applicable federal, state, and local regulations and guidelines. Clinical findings and feed consumption were recorded weekly for rats and mice. The animals were weighed initially, weekly, and at the end of the studies. Details of the study design and animal maintenance are summarized in Table 1. Information on feed composition and contaminants is provided in Appendix H.

Animals were anesthetized with $70 \% \mathrm{CO}_{2}: 30 \% \mathrm{O}_{2}$, and blood was collected from the retroorbital sinus of clinical pathology rats on days 4 and 22 and from core study rats at the end of the study for hematology and clinical chemistry analyses; blood was collected from the retroorbital sinus of mice at the end of the study for hematology analyses. Hematology parameters were measured using an ABX Penta C+ Analyzer (Horiba Instruments, Ann Arbor, MI). Clinical chemistry analyses were performed using a Hitachi 717 (Roche Diagnostics, Indianapolis, IN). The parameters measured are listed in Table 1.

At the end of the 3-month studies, samples were collected for sperm motility and vaginal cytology evaluations on core study rats and mice exposed to 0, 45 (rats only), 90, 180, and 360 (mice only) $\mathrm{mg} / \mathrm{kg}$. The parameters evaluated are listed in Table 1. For 12 consecutive days prior to scheduled terminal kill, the vaginal vaults of the females were moistened with saline, if necessary, and samples of vaginal fluid and cells were stained. Relative numbers of leukocytes, nucleated epithelial cells, and large squamous epithelial cells were determined and used to ascertain estrous cycle stage (i.e., diestrus, proestrus, estrus, and metestrus). Male animals were evaluated for sperm count and motility. The left testis and left epididymis were isolated and weighed. The tail of the epididymis (cauda epididymis) was then removed from the epididymal body (corpus epididymis) and weighed. Test yolk (rats) or modified Tyrode's buffer (mice) was 
applied to slides, and a small incision was made at the distal border of the cauda epididymis. The sperm effluxing from the incision were dispersed in the buffer on the slides, and the numbers of motile and nonmotile spermatozoa were counted for five fields per slide by two observers. Following completion of sperm motility estimates, each left cauda epididymis was placed in buffered saline solution. Caudae were finely minced, and the tissue was incubated in the saline solution and then heat fixed at $65^{\circ} \mathrm{C}$. Sperm density was then determined microscopically with the aid of a hemacytometer. To quantify spermatogenesis, the testicular spermatid head count was determined by removing the tunica albuginea and homogenizing the left testis in phosphatebuffered saline containing 10\% dimethyl sulfoxide. Homogenization-resistant spermatid nuclei were counted with a hemacytometer.

Necropsies were performed on all core study animals. The heart, right kidney, liver, lung, spleen, right testis, thymus, and thyroid gland were weighed. Tissues for microscopic examination were fixed and preserved in 10\% neutral buffered formalin, processed and trimmed, embedded in paraffin, sectioned to a thickness of 4 to $6 \mu \mathrm{m}$, and stained with hematoxylin and eosin. Complete histopathologic examinations were performed by the study laboratory pathologist on the vehicle control groups of rats and mice, $180 \mathrm{mg} / \mathrm{kg}$ rats, and $360 \mathrm{mg} / \mathrm{kg}$ mice. The skin was examined in all remaining groups of rats and mice. Table 1 lists the tissues and organs routinely examined.

After a review of the laboratory reports and selected histopathology slides by a quality assessment (QA) pathologist, the findings and reviewed slides were submitted to a NTP Pathology Working Group (PWG) coordinator for a second independent review. Any inconsistencies in the diagnoses made by the study laboratory and QA pathologists were resolved by the NTP pathology peer review process. Final diagnoses for reviewed lesions represent a consensus of the PWG or a consensus between the study laboratory pathologist, NTP pathologist, QA pathologist(s), if any, and the PWG coordinator. Details of these review procedures have been described, in part, by Maronpot and Boorman ${ }^{28}$ and Boorman et al. ${ }^{29}$.

Table 1. Experimental Design and Materials and Methods in the Dermal Studies of Sodium Thioglycolate

\begin{tabular}{|c|c|}
\hline Two-week Studies & Three-month Studies \\
\hline \multicolumn{2}{|l|}{ Study Laboratory } \\
\hline BioReliance Corporation (Rockville, MD) & BioReliance Corporation (Rockville, MD) \\
\hline \multicolumn{2}{|l|}{ Strain and Species } \\
\hline $\mathrm{F} 344 / \mathrm{N}$ rats & $\mathrm{F} 344 / \mathrm{N}$ rats \\
\hline B6C3F1/N mice & B6C3F1/N mice \\
\hline \multicolumn{2}{|l|}{ Animal Source } \\
\hline Taconic Farms, Inc. (Germantown, NY) & Taconic Farms, Inc. (Germantown, NY) \\
\hline \multicolumn{2}{|l|}{ Time Held Before Studies } \\
\hline 12 days & $\begin{array}{l}\text { Rats: } 13 \text { (males) or } 14 \text { (females) days } \\
\text { Mice: } 16 \text { (males) or } 17 \text { (females) days }\end{array}$ \\
\hline \multicolumn{2}{|l|}{ Average Age When Studies Began } \\
\hline 6 weeks & 5 to 6 weeks \\
\hline
\end{tabular}




\section{Date of First Dose}

January 16, 2001

\section{Duration of Dosing}

Rats: 5 exposures per week for 16 calendar days Mice: 5 exposures per week for 17 calendar days

\section{Date of Last Dose}

Rats: January 31, 2001

Mice: February 1, 2001

\section{Necropsy Dates}

Rats: February 1, 2001

Mice: February 2, 2001

Average Age at Necropsy

8 to 9 weeks

Size of Study Groups

5 males and 5 females

\section{Method of Distribution}

Animals were distributed randomly into groups of approximately equal initial mean body weights

\section{Animals per Cage}

1

\section{Method of Animal Identification}

Tail tattoo

\section{Diet}

NTP-2000 irradiated wafer diet (Zeigler Brothers, Inc., Gardners, PA), available ad libitum, changed weekly

\section{Water}

Tap water (Washington Suburban Sanitary Commission Potomac Plant) via automatic watering system (Edstrom Industries, Inc., Waterford, WI), available ad libitum

\section{Cages}

Solid-bottom polycarbonate (Lab Products, Inc., Seaford, DE), changed once a week

\section{Bedding}

Irradiated, heat-treated hardwood chips (P.J. Murphy Forest Products, Inc., Montville, NJ), changed once a week
Rats: December 16, 2002

Mice: December 19, 2002

Core study (rats and mice): 5 exposures per week for 14 weeks

Special study (rats): 5 exposures per week for 22 days

Rats: March 18, 2003

Mice: March 20, 2003

Rats: March 18 (males) or 19 (females), 2003

Mice: March 20 (males) or 21 (females), 2003

18 to 19 weeks

10 males and 10 females

Same as 2-week studies

1

Tail tattoo

Same as 2-week studies, except meal form, changed weekly, except male rats changed twice weekly beginning January 24, 2003

Same as 2-week studies

Same as 2-week studies

Same as 2-week studies 


\section{Cage Filters}

Remay 2016 (Snow Filtration, West Chester, OH), changed every 2 weeks

\section{Racks}

Stainless steel (Lab Products, Inc., Seaford, DE), changed every 2 weeks

\section{Animal Room Environment}

Temperature: $72^{\circ} \pm 3^{\circ} \mathrm{F}$

Relative humidity: $50 \% \pm 15 \%$

Room fluorescent light: 12 hours/day

Room air changes: 10/hour

Doses

Rats: $0,11.25,22.5,45,90$, or $180 \mathrm{mg} / \mathrm{kg}$ in $95 \%$ ethanol:deionized water $(1: 1)$, dosing volume $0.5 \mathrm{~mL} / \mathrm{kg}$

Mice: $0,22.5,45,90,180$, or $360 \mathrm{mg} / \mathrm{kg}$ in $95 \%$ ethanol:deionized water $(1: 1)$, dosing volume $2.0 \mathrm{~mL} / \mathrm{kg}$

\section{Type and Frequency of Observation}

Observed twice daily; animals were weighed initially, on day 8 , and at the end of the studies; clinical findings were recorded daily.

\section{Method of Kill}

Carbon dioxide asphyxiation

\section{Necropsy}

Necropsies were performed on all animals. Organs weighed were heart, right kidney, liver, lung, spleen, right testis, thymus, and thyroid gland.

\section{Clinical Pathology}

None
Same as 2-week studies

Same as 2-week studies

Temperature: $72^{\circ} \pm 3^{\circ} \mathrm{F}$

Relative humidity: $50 \% \pm 15 \%$

Room fluorescent light: 12 hours/day

Room air changes: 10/hour

Rats: $0,11.25,22.5,45,90$ or $180 \mathrm{mg} / \mathrm{kg}$ in $95 \%$ ethanol:deionized water $(1: 1)$, dosing volume $0.5 \mathrm{~mL} / \mathrm{kg}$

Mice: $0,22.5,45,90,180$, or $360 \mathrm{mg} / \mathrm{kg}$ in $95 \%$ ethanol:deionized water $(1: 1)$, dosing volume $2.0 \mathrm{~mL} / \mathrm{kg}$

Observed twice daily; animals were weighed initially, weekly, and at the end of the studies; clinical findings and feed consumption were recorded weekly.

Same as 2-week studies

Necropsies were performed on all core study animals. Organs weighed were heart, right kidney, liver, lung, spleen, right testis, thymus, and thyroid gland.

Blood was collected from the retroorbital sinus of clinical pathology study rats on days 4 and 22 and from core study rats and mice at the end of the studies for hematology (rats and mice) and clinical chemistry (rats). Hematology: hematocrit; hemoglobin concentration; erythrocyte, reticulocyte, and platelet counts; mean cell volume; mean cell hemoglobin; mean cell hemoglobin concentration; and leukocyte count and differentials Clinical chemistry: urea nitrogen, creatinine, total protein, albumin, alanine aminotransferase, alkaline phosphatase, creatine kinase, sorbitol dehydrogenase, total bile acids, globulin, albumin-globulin ratio, total cholesterol, free fatty acids, and 3-hydroxybutyrate 


\section{Histopathology}

Histopathology was performed on all vehicle control rats and mice, $180 \mathrm{mg} / \mathrm{kg}$ rats, and $360 \mathrm{mg} / \mathrm{kg}$ mice. In addition to gross lesions and tissue masses, the following tissues were examined to a no-effect level: eyes, Harderian gland, kidney, liver, lung, pituitary gland, skin (site of application and control), spleen, stomach (forestomach and glandular), and thyroid gland.

Complete histopathology was performed on all vehicle control rats and mice, $180 \mathrm{mg} / \mathrm{kg}$ rats, and $360 \mathrm{mg} / \mathrm{kg}$ mice. In addition to gross lesions and tissue masses, the following tissues were examined: adrenal gland, bone with marrow, brain, clitoral gland, esophagus, eyes, gallbladder (mice only), Harderian gland, heart and aorta, large intestine (cecum, colon, rectum), small intestine (duodenum, jejunum, ileum), kidney, liver, lung (with bronchus), lymph nodes (mandibular and mesenteric), mammary gland, nose, ovary, pancreas, pancreatic islets, parathyroid gland, pituitary gland, preputial gland, prostate gland, salivary gland, seminal vesicle, skin (site of application and control), spleen, stomach (forestomach and glandular), testis (with epididymis), thymus, thyroid gland, trachea, urinary bladder, and uterus. The skin was also examined in the remaining dosed groups.

\section{Sperm Motility and Vaginal Cytology}

None

At the end of the studies, sperm samples were collected from male animals exposed to 0,45 (rats only), 90, 180, and 360 (mice only) $\mathrm{mg} / \mathrm{kg}$ for sperm count and motility evaluations. The following parameters were evaluated: spermatid heads per testis and per gram testis, sperm counts, and epididymal spermatozoal motility and concentration. The left cauda, left epididymis, and left testis were weighed. Vaginal samples were collected for up to 12 consecutive days prior to the end of the studies from females exposed to 0,45 (rats only), 90, 180, and 360 (mice only) $\mathrm{mg} / \mathrm{kg}$ for vaginal cytology evaluations.

\section{Statistical Methods}

\section{Calculation and Analysis of Lesion Incidences}

The incidences of lesions are presented in Appendix A as the numbers of animals bearing such lesions at a specific anatomic site and the numbers of animals with that site examined microscopically. The Fisher exact test ${ }^{30}$, a procedure based on the overall proportion of affected animals, was used to determine significance.

\section{Analysis of Continuous Variables}

Two approaches were employed to assess the significance of pairwise comparisons between dosed and control groups in the analysis of continuous variables. Organ and body weight data, which historically have approximately normal distributions, were analyzed with the parametric multiple comparison procedures of Dunnett ${ }^{31}$ and Williams ${ }^{32 ; 33}$. Hematology, clinical chemistry, spermatid, and epididymal spermatozoal data, which have typically skewed distributions, were analyzed using the nonparametric multiple comparison methods of Shirley ${ }^{34}$ (as modified by Williams ${ }^{35}$ ) and Dunn ${ }^{36}$. Jonckheere's test ${ }^{37}$ was used to assess the significance of the doserelated trends and to determine whether a trend-sensitive test (Williams' or Shirley's test) was 
more appropriate for pairwise comparisons than a test that does not assume a monotonic doserelated trend (Dunnett's or Dunn's test). Prior to statistical analysis, extreme values identified by the outlier test of Dixon and Massey ${ }^{38}$ were examined by NTP personnel, and implausible values were eliminated from the analysis. Proportions of regular cycling females in each dosed group were compared to the control group using the Fisher exact test ${ }^{30}$. Tests for extended periods of estrus, diestrus, metestrus, and proestrus, as well as skipped estrus and skipped diestrus, were constructed based on a Markov chain model proposed by Girard and Sager ${ }^{39}$. For each dose group, a transition probability matrix was estimated for transitions among the proestrus, estrus, metestrus, and diestrus stages, with provision for extended stays within each stage as well as for skipping estrus or diestrus within a cycle. Equality of transition matrices among dose groups and between the control group and each dosed group was tested using chi-square statistics.

\section{Quality Assurance Methods}

The 2-week and 3-month studies were conducted in compliance with Food and Drug Administration Good Laboratory Practice Regulations ${ }^{40}$. The Quality Assurance Unit of BioReliance Corporation performed audits and inspections of protocols, procedures, data, and reports throughout the course of the studies.

\section{Genetic Toxicology}

\section{Salmonella typhimurium Mutagenicity Test Protocol}

Testing was performed as reported by Zeiger et al. ${ }^{27}$. Sodium thioglycolate was sent to the laboratory as a coded aliquot from Radian Corporation (Austin, TX). It was incubated with the Salmonella typhimurium tester strains TA98, TA100, TA1535, and TA1537 either in buffer or S9 mix (metabolic activation enzymes and cofactors from Aroclor 1254-induced male Sprague Dawley rat or Syrian hamster liver) for 20 minutes at $37^{\circ} \mathrm{C}$. Top agar supplemented with Lhistidine and d-biotin was added, and the contents of the tubes were mixed and poured onto the surfaces of minimal glucose agar plates. Histidine-independent mutant colonies arising on these plates were counted following incubation for 2 days at $37^{\circ} \mathrm{C}$.

Each trial consisted of triplicate plates of concurrent positive and negative controls and five doses of sodium thioglycolate. The high dose was limited by toxicity. All trials were repeated, except TA1535 with $10 \%$ rat S9.

In this assay, a positive response is defined as a reproducible, dose-related increase in histidineindependent (revertant) colonies in any one strain/activation combination. An equivocal response is defined as an increase in revertants that is not dose related, is not reproducible, or is not of sufficient magnitude to support a determination of mutagenicity. A negative response is obtained when no increase in revertant colonies is observed following chemical treatment. There is no minimum percentage or fold increase required for a chemical to be judged positive or weakly positive, although positive calls are typically reserved for increases in mutant colonies that are at least twofold over background.

\section{Mouse Peripheral Blood Micronucleus Test Protocol}

A detailed discussion of this assay is presented by MacGregor et al. ${ }^{41}$. At the end of the 3-month toxicity study, peripheral blood samples were obtained from male and female mice. Smears were 
immediately prepared and fixed in absolute methanol. The methanol-fixed slides were stained with acridine orange and coded. Slides were scanned to determine the frequency of micronuclei in 2,000 normochromatic erythrocytes (NCEs) in each of five animals per dose group. In addition, the percentage of polychromatic erythrocytes in a population of 1,000 erythrocytes was determined as a measure of bone marrow toxicity.

The results were tabulated as the mean of the pooled results from all animals within a treatment group plus or minus the standard error of the mean. The frequency of micronucleated cells among NCEs was analyzed by a statistical software package that tested for increasing trend over dose groups with a one-tailed Cochran-Armitage trend test, followed by pairwise comparisons between each dosed group and the vehicle control group. In the presence of excess binomial variation, as detected by a binomial dispersion test, the binomial variance of the CochranArmitage test was adjusted upward in proportion to the excess variation. In the micronucleus test, an individual trial is considered positive if the trend test $\mathrm{P}$ value is less than or equal to 0.025 or if the $\mathrm{P}$ value for any single dosed group is less than or equal to 0.025 divided by the number of dosed groups. A final call of positive for micronucleus induction is preferably based on reproducibly positive trials (as noted above). Ultimately, the final call is determined by the scientific staff after considering the results of statistical analyses, the reproducibility of any effects observed, and the magnitudes of those effects.

\section{Evaluation Protocol}

These are the basic guidelines for arriving at an overall assay result for assays performed by the National Toxicology Program. Statistical as well as biological factors are considered. For an individual assay, the statistical procedures for data analysis have been described in the preceding protocols. There have been instances, however, in which multiple samples of a chemical were tested in the same assay, and different results were obtained among these samples and/or among laboratories. Results from more than one aliquot or from more than one laboratory are not simply combined into an overall result. Rather, all the data are critically evaluated, particularly with regard to pertinent protocol variations, in determining the weight of evidence for an overall conclusion of chemical activity in an assay. In addition to multiple aliquots, the in vitro assays have another variable that must be considered in arriving at an overall test result. In vitro assays are conducted with and without exogenous metabolic activation. Results obtained in the absence of activation are not combined with results obtained in the presence of activation; each testing condition is evaluated separately. The results presented in the Abstract of this Toxicity Study Report represent a scientific judgment of the overall evidence for activity of the chemical in an assay. 


\section{Results}

\section{Rats}

\section{Two-week Study}

All rats survived to the end of the study (Table 2). Mean body weights of dosed groups were similar to those of the vehicle control groups. On day 17 , all $180 \mathrm{mg} / \mathrm{kg}$ males, two $90 \mathrm{mg} / \mathrm{kg}$ females, and two $180 \mathrm{mg} / \mathrm{kg}$ females had irritation at the site of application.

Table 2. Survival and Body Weights of Rats in the Two-week Dermal Study of Sodium Thioglycolate $^{\mathrm{a}}$

\begin{tabular}{cccccc}
\hline Dose (mg/kg) & Survival $^{\mathbf{b}}$ & $\begin{array}{c}\text { Initial Body } \\
\text { Weight (g) }\end{array}$ & $\begin{array}{c}\text { Final Body } \\
\text { Weight (g) }\end{array}$ & $\begin{array}{c}\text { Change in Body } \\
\text { Weight (g) }\end{array}$ & $\begin{array}{c}\text { Final Weight } \\
\text { Relative to } \\
\text { Controls (\%) }\end{array}$ \\
\hline Male & & & & & \\
0 & $5 / 5$ & $86 \pm 6$ & $151 \pm 11$ & $65 \pm 4$ & 98 \\
11.25 & $5 / 5$ & $93 \pm 2$ & $148 \pm 4$ & $56 \pm 3$ & 107 \\
22.5 & $5 / 5$ & $93 \pm 2$ & $162 \pm 4$ & $69 \pm 3$ & 101 \\
45 & $5 / 5$ & $87 \pm 4$ & $152 \pm 5$ & $65 \pm 3$ & 109 \\
90 & $5 / 5$ & $92 \pm 1$ & $164 \pm 4$ & $72 \pm 4$ & 107 \\
180 & $5 / 5$ & $91 \pm 2$ & $162 \pm 6$ & $71 \pm 4$ & 92 \\
\hline Female & & & & & 90 \\
0 & $5 / 5$ & $89 \pm 2$ & $128 \pm 3$ & $38 \pm 2$ & 93 \\
11.25 & $5 / 5$ & $81 \pm 5$ & $117 \pm 6$ & $37 \pm 3$ & 94 \\
22.5 & $5 / 5$ & $88 \pm 1$ & $115 \pm 3$ & $27 \pm 3$ & 98 \\
\hline 50 & $5 / 5$ & $86 \pm 5$ & $118 \pm 5$ & $32 \pm 5$ & $27 \pm 3$ \\
180 & $5 / 5$ & $92 \pm 2$ & $120 \pm 2$ & $36 \pm 2$ & \\
\hline
\end{tabular}

${ }^{\mathrm{a}}$ Weights and weight changes are given as mean \pm standard error. Differences from the vehicle control group are not significant by Dunnett's test.

${ }^{\mathrm{b}}$ Number of animals surviving at day $17 /$ number initially in group.

Absolute kidney weights were significantly increased in 90 and $180 \mathrm{mg} / \mathrm{kg}$ males; relative kidney weights were significantly increased in $180 \mathrm{mg} / \mathrm{kg}$ males (Table 3 and Table D-1). Absolute and relative liver weights were significantly increased in $180 \mathrm{mg} / \mathrm{kg}$ males. Absolute and relative lung weights were significantly decreased in all groups of dosed males. Minimal epidermal hyperplasia occurred in male and female rats administered $45 \mathrm{mg} / \mathrm{kg}$ or greater (male: $0 / 5,0 / 5,0 / 5,4 / 5,2 / 5,4 / 5$; female: $0 / 5,0 / 5,0 / 5,2 / 5,2 / 5,4 / 5)$. Mild cytoplasmic focal vacuolization of the centrilobular hepatocytes occurred in all groups of dosed males $(0 / 5,2 / 5$, $3 / 5,3 / 5,3 / 5,4 / 5)$. There were no histopathologic findings associated with the changes in kidney or lung weights in male rats. Other than epidermal hyperplasia, no effects were observed in female rats. 
Dose Selection Rationale: Due to the lack of systemic toxicity and minimal dermal toxicity at the site of application, the sodium thioglycolate doses selected for the 3-month rat study were the same as those used in the 2-week study.

Table 3. Selected Organ Weights and Organ-Weight-to-Body-Weight Ratios for Male Rats in the Two-week Dermal Study of Sodium Thioglycolate ${ }^{a}$

\begin{tabular}{|c|c|c|c|c|c|c|}
\hline & Vehicle Control & $11.25 \mathrm{mg} / \mathrm{kg}$ & $22.5 \mathrm{mg} / \mathrm{kg}$ & $45 \mathrm{mg} / \mathrm{kg}$ & $90 \mathrm{mg} / \mathrm{kg}$ & $180 \mathrm{mg} / \mathrm{kg}$ \\
\hline $\mathbf{n}$ & 5 & 5 & 5 & 5 & 5 & 5 \\
\hline $\begin{array}{l}\text { Necropsy } \\
\text { body wt }\end{array}$ & $151 \pm 11$ & $148 \pm 4$ & $162 \pm 4$ & $152 \pm 5$ & $164 \pm 4$ & $162 \pm 6$ \\
\hline \multicolumn{7}{|l|}{ R. Kidney } \\
\hline Absolute & $0.719 \pm 0.037$ & $0.738 \pm 0.025$ & $0.811 \pm 0.028$ & $0.754 \pm .037$ & $0.823 \pm 0.026^{*}$ & $0.861 \pm 0.033 * *$ \\
\hline Relative & $4.790 \pm 0.107$ & $4.977 \pm 0.072$ & $4.994 \pm 0.077$ & $4.952 \pm 0.111$ & $5.003 \pm 0.109$ & $5.325 \pm 0.118^{* *}$ \\
\hline \multicolumn{7}{|l|}{ Liver } \\
\hline Absolute & $7.921 \pm 0.632$ & $8.080 \pm 0.301$ & $8.715 \pm 0.299$ & $7.817 \pm .309$ & $9.082 \pm 0.363$ & $9.525 \pm 0.375^{*}$ \\
\hline Relative & $52.348 \pm 1.267$ & $54.567 \pm 1.960$ & $53.696 \pm 1.035$ & $51.460 \pm 1.353$ & $55.256 \pm 1.972$ & $58.881 \pm 0.842 *$ \\
\hline \multicolumn{7}{|l|}{ Lung } \\
\hline Absolute & $1.801 \pm 0.067$ & $0.996 \pm 0.031 * *$ & $1.054 \pm 0.052 * *$ & $0.954 \pm 0.056^{* *}$ & $0.991 \pm 0.060 * *$ & $0.990 \pm 0.061 * *$ \\
\hline Relative & $12.220 \pm 1.155$ & $6.728 \pm 0.205^{* *}$ & $6.511 \pm 0.361 * *$ & $6.274 \pm 0.285^{* *}$ & $6.011 \pm 0.257 * *$ & $6.129 \pm 0.347 * *$ \\
\hline
\end{tabular}

*Significantly different $(\mathrm{P} \leq 0.05)$ from the vehicle control group by Williams' or Dunnett's test. $* * \mathrm{P} \leq 0.01$

${ }^{\mathrm{a}}$ Organ weights (absolute weights) and body weights are given in grams; organ-weight-to-body-weight ratios (relative weights) are given as mg organ weight/g body weight (mean \pm standard error).

\section{Three-month Study}

All rats survived to the end of the study; final mean body weights and body weight gains of 90 and $180 \mathrm{mg} / \mathrm{kg}$ males were significantly less than those of the vehicle controls, but were within $10 \%$ of vehicle control values (Table 4 and Figure 2). Feed consumption by dosed groups of male and female rats was generally similar to that by the vehicle control groups (Table G-1 and Table G-2). All dosed rats developed irritation at the site of application. Thickening of the skin at the site of application in 90 and $180 \mathrm{mg} / \mathrm{kg}$ males and in females administered $45 \mathrm{mg} / \mathrm{kg}$ or greater and ulceration of the skin at the site of application in 90 and $180 \mathrm{mg} / \mathrm{kg}$ males and females were observed. 
Table 4. Survival and Body Weights of Rats in the Three-month Dermal Study of Sodium Thioglycolate $^{\mathrm{a}}$

\begin{tabular}{cccccc}
\hline Dose (mg/kg) & Survival $^{\mathbf{b}}$ & $\begin{array}{c}\text { Initial Body } \\
\text { Weight (g) }\end{array}$ & $\begin{array}{c}\text { Final Body } \\
\text { Weight }(\mathbf{g})\end{array}$ & $\begin{array}{c}\text { Change in Body } \\
\text { Weight (g) }\end{array}$ & $\begin{array}{c}\text { Final Weight } \\
\text { Relative to } \\
\text { Controls (\%) }\end{array}$ \\
\hline Male & & & & & \\
0 & $10 / 10$ & $93 \pm 2$ & $335 \pm 4$ & $242 \pm 4$ & 100 \\
11.25 & $10 / 10$ & $92 \pm 2$ & $334 \pm 4$ & $242 \pm 4$ & 99 \\
22.5 & $10 / 10$ & $91 \pm 3$ & $332 \pm 7$ & $241 \pm 6$ & 101 \\
45 & $10 / 10$ & $94 \pm 3$ & $339 \pm 5$ & $246 \pm 3$ & 93 \\
90 & $10 / 10$ & $90 \pm 3$ & $312 \pm 9 *$ & $222 \pm 7^{*}$ & 95 \\
180 & $10 / 10$ & $92 \pm 3$ & $319 \pm 6^{*}$ & $227 \pm 5^{*}$ & 105 \\
\hline Female & & & & & 106 \\
0 & $10 / 10$ & $85 \pm 2$ & $177 \pm 3$ & $92 \pm 2$ & 105 \\
11.25 & $10 / 10$ & $84 \pm 2$ & $185 \pm 3$ & $101 \pm 2^{*}$ & 101 \\
22.5 & $10 / 10$ & $85 \pm 2$ & $185 \pm 3$ & $100 \pm 2$ & 98 \\
\hline 45 & $10 / 10$ & $86 \pm 2$ & $186 \pm 3$ & $100 \pm 2$ & \\
90 & $10 / 10$ & $83 \pm 2$ & $180 \pm 4$ & $97 \pm 3$ & $91 \pm 2$ \\
180 & $10 / 10$ & $82 \pm 3$ & $173 \pm 4$ & & \\
\hline
\end{tabular}

*Significantly different $(\mathrm{P} \leq 0.05)$ from the vehicle control group by Williams' or Dunnett's test.

${ }^{a}$ Weights and weight changes are given as mean \pm standard error.

${ }^{b}$ Number of animals surviving at 3 months/number initially in group. 
Sodium Thioglycolate, NTP TOX 80
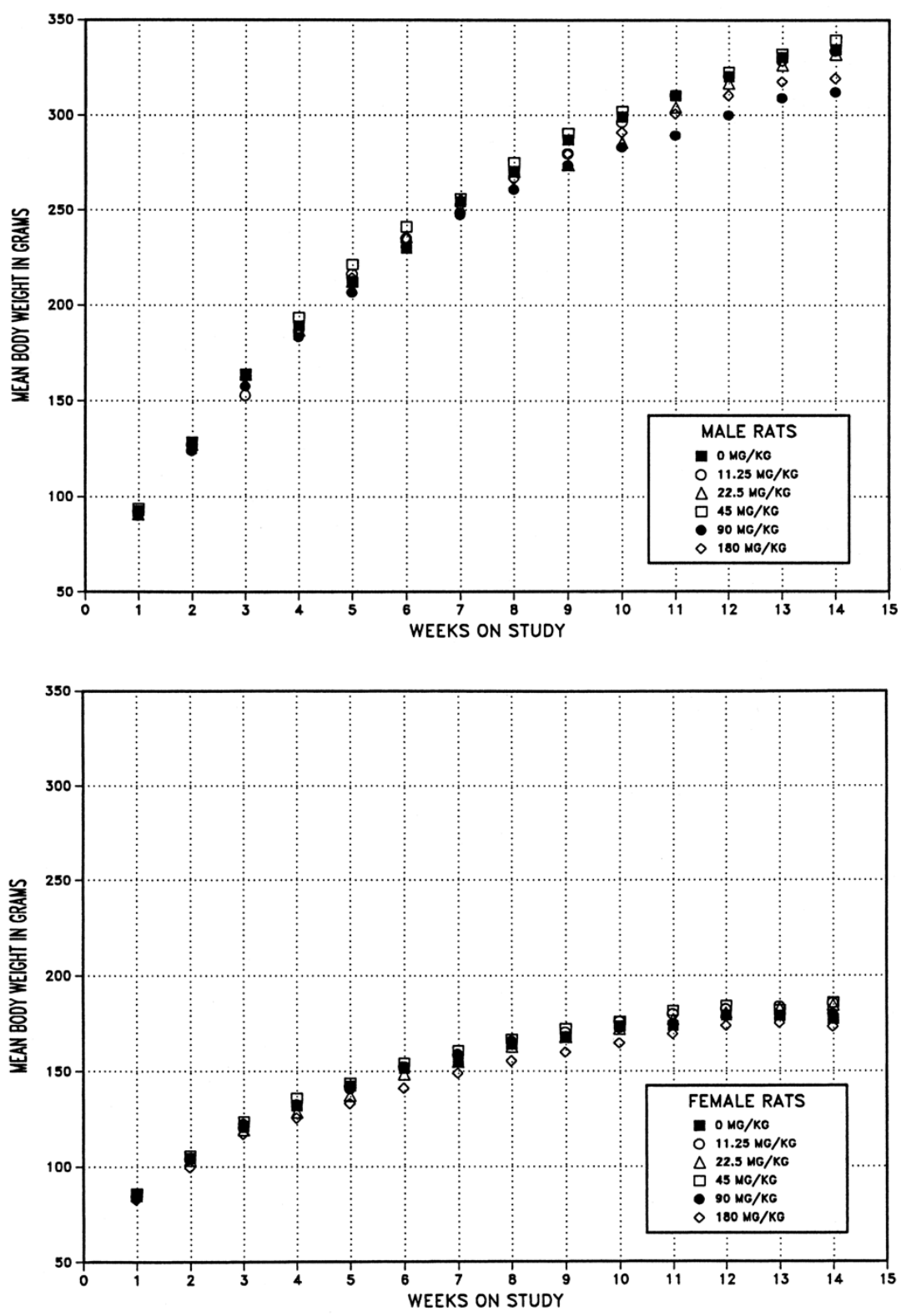

Figure 2. Growth Curves for Rats Administered Sodium Thioglycolate Dermally for Three Months 
No chemical-related changes in hematology or clinical chemistry variables occurred (Table C-1). Organ weight changes were considered sporadic or related to a decrease in body weight so were not considered to be biologically significant (Table D-2). There were no significant differences in sperm parameters of male rats or estrous cyclicity of female rats administered 45, 90, or $180 \mathrm{mg} / \mathrm{kg}$ sodium thioglycolate when compared to the vehicle controls (Table E-1 and Table E-2).

Chemical-related nonneoplastic lesions were limited to the site of application (Table 5, Table A-1, and Table A-2). These lesions included epidermal hyperplasia (thickening), hyperkeratosis (thickening of the stratum corneum), sebaceous gland hypertrophy (increase in the size of the cells), and ulcers (discontinuity in the epithelial surface that extended through the full thickness of the epithelial surface) (Figure 4 and Figure 5). Lesions were minimal to mild, involving all treatment groups. Ulceration was noted only in three females treated with $180 \mathrm{mg} / \mathrm{kg}$. The following severity criteria were applied to grade the epidermal hyperplasia: minimal hyperplasia was two to three cell layers thick; mild was four to six cell layers thick; moderate was seven to eight cell layers thick; and marked was equal to or greater than nine cell layers thick.

Table 5. Incidences of Nonneoplastic Lesions of the Skin at the Site of Application in Rats in the Three-month Dermal Study of Sodium Thioglycolate

\begin{tabular}{|c|c|c|c|c|c|c|}
\hline & $\begin{array}{l}\text { Vehicle } \\
\text { Control } \\
\end{array}$ & $11.25 \mathrm{mg} / \mathrm{kg}$ & $22.5 \mathrm{mg} / \mathrm{kg}$ & $45 \mathrm{mg} / \mathrm{kg}$ & $90 \mathrm{mg} / \mathrm{kg}$ & $180 \mathrm{mg} / \mathrm{kg}$ \\
\hline \multicolumn{7}{|l|}{ Male } \\
\hline $\begin{array}{l}\text { Number Examined } \\
\text { Microscopically }\end{array}$ & 10 & 10 & 10 & 10 & 10 & 10 \\
\hline $\begin{array}{l}\text { Sebaceous Gland, } \\
\text { Dermis, Hypertrophy }\end{array}$ & 0 & 0 & $2(1.0)^{\mathrm{b}}$ & $4^{*}(1.0)$ & $5^{*}(1.0)$ & $6 * *(1.0)$ \\
\hline $\begin{array}{l}\text { Epidermis, } \\
\text { Hyperkeratosis }\end{array}$ & 0 & $6 * *(1.0)$ & $9 * *(1.0)$ & $4^{*}(1.0)$ & $4 *(1.0)$ & $4 *(1.0)$ \\
\hline $\begin{array}{l}\text { Epidermis, } \\
\text { Hyperplasia, Diffuse }\end{array}$ & 0 & $1(1.0)$ & $2(1.0)$ & $3(1.0)$ & $5^{*}(1.0)$ & $6 * *(1.0)$ \\
\hline \multicolumn{7}{|l|}{ Female } \\
\hline $\begin{array}{l}\text { Number Examined } \\
\text { Microscopically }\end{array}$ & 10 & 10 & 10 & 10 & 10 & 10 \\
\hline $\begin{array}{l}\text { Sebaceous Gland, } \\
\text { Dermis, Hypertrophy }\end{array}$ & 0 & 0 & 0 & $2(1.0)$ & $6 * *(1.0)$ & $5 *(1.0)$ \\
\hline $\begin{array}{l}\text { Epidermis, } \\
\text { Hyperkeratosis }\end{array}$ & 0 & 0 & $1(1.0)$ & $7 * *(1.0)$ & $6^{* *}(1.0)$ & $5 *(1.0)$ \\
\hline $\begin{array}{l}\text { Epidermis, } \\
\text { Hyperplasia, Diffuse }\end{array}$ & 0 & 0 & 0 & $2(1.0)$ & $7 * *(1.3)$ & $8 * *(1.5)$ \\
\hline $\begin{array}{l}\text { Epidermis, Ulcer, } \\
\text { Focal }\end{array}$ & 0 & 0 & 0 & 0 & 0 & $3(1.0)$ \\
\hline
\end{tabular}




\section{Mice}

\section{Two-week Study}

All male mice survived to the end of the study; one $360 \mathrm{mg} / \mathrm{kg}$ female was found dead on day 5 with cause of death unknown: no clinical findings, gross lesions, or significant histologic lesions were observed (Table 6). The mean body weight gain of $180 \mathrm{mg} / \mathrm{kg}$ males was significantly greater than that of the vehicle control group. No clinical findings attributed to sodium thioglycolate administration were observed. No biologically significant organ weight differences were observed (Table D-3).

No chemical-related gross lesions were observed. Minimal to mild epidermal hyperplasia occurred in male mice administered $90 \mathrm{mg} / \mathrm{kg}$ or greater and in female mice administered $45 \mathrm{mg} / \mathrm{kg}$ or greater (male: $0 / 5,0 / 5,0 / 5,3 / 5,5 / 5,5 / 5$; female: $0 / 5,0 / 5,1 / 5,3 / 5,4 / 5,3 / 5$ ).

Dose Selection Rationale: Due to the lack of systemic toxicity and minimal dermal toxicity at the site of application, the sodium thioglycolate doses selected for the 3-month mouse study were the same as those used in the 2-week study.

Table 6. Survival and Body Weights of Mice in the Two-week Dermal Study of Sodium Thioglycolate ${ }^{\mathrm{a}}$

\begin{tabular}{|c|c|c|c|c|c|}
\hline Dose (mg/kg) & Survival $^{\text {b }}$ & $\begin{array}{c}\text { Initial Body } \\
\text { Weight (g) }\end{array}$ & $\begin{array}{l}\text { Final Body } \\
\text { Weight (g) }\end{array}$ & $\begin{array}{l}\text { Change in Body } \\
\text { Weight (g) }\end{array}$ & $\begin{array}{l}\text { Final Weight } \\
\text { Relative to } \\
\text { Controls (\%) }\end{array}$ \\
\hline \multicolumn{6}{|l|}{ Male } \\
\hline 0 & $5 / 5$ & $21.4 \pm 0.6$ & $23.6 \pm 0.5$ & $2.2 \pm 0.4$ & \\
\hline 22.5 & $5 / 5$ & $20.8 \pm 0.5$ & $23.5 \pm 0.3$ & $2.7 \pm 0.3$ & 99 \\
\hline 45 & $5 / 5$ & $21.5 \pm 0.7$ & $24.7 \pm 0.9$ & $3.2 \pm 0.4$ & 105 \\
\hline 90 & $5 / 5$ & $21.5 \pm 0.3$ & $23.9 \pm 0.3$ & $2.4 \pm 0.3$ & 101 \\
\hline 180 & $5 / 5$ & $21.3 \pm 0.4$ & $25.1 \pm 0.4$ & $3.8 \pm 0.2 * *$ & 106 \\
\hline 360 & $5 / 5$ & $21.5 \pm 0.4$ & $24.7 \pm 0.4$ & $3.2 \pm 0.2$ & 105 \\
\hline \multicolumn{6}{|l|}{ Female } \\
\hline 0 & $5 / 5$ & $18.2 \pm 0.2$ & $21.3 \pm 0.2$ & $3.1 \pm 0.2$ & \\
\hline 22.5 & $5 / 5$ & $18.3 \pm 0.3$ & $21.2 \pm 0.3$ & $2.9 \pm 0.4$ & 100 \\
\hline 45 & $5 / 5$ & $18.9 \pm 0.4$ & $21.5 \pm 0.2$ & $2.6 \pm 0.3$ & 101 \\
\hline 90 & $5 / 5$ & $18.4 \pm 0.6$ & $21.8 \pm 0.3$ & $3.3 \pm 0.7$ & 102 \\
\hline 180 & $5 / 5$ & $18.3 \pm 0.5$ & $22.1 \pm 0.5$ & $3.9 \pm 0.5$ & 104 \\
\hline 360 & $4 / 5^{\mathrm{c}}$ & $18.3 \pm 0.6$ & $22.2 \pm 0.6$ & $3.9 \pm 0.4$ & 104 \\
\hline
\end{tabular}

**Significantly different $(\mathrm{P} \leq 0.01)$ from the vehicle control group by Dunnett's test.

${ }^{a}$ Weights and weight changes are given as mean \pm standard error. Subsequent calculations are based on animals surviving to the end of the study.

${ }^{b}$ Number of animals surviving at day 18 /number initially in group.

'Day of death: 5 . 


\section{Three-month Study}

All mice survived to the end of the study; mean body weights of dosed groups were similar to those of the vehicle control groups (Table 7; Figure 3). Feed consumption by dosed groups of male and female mice was generally similar to that of the vehicle control groups (Table G-3 and Table G-4). Six $360 \mathrm{mg} / \mathrm{kg}$ males developed irritation at the site of application.

The hematology data for mice are listed in Table C-2. Minimal $(<8 \%)$ treatment- but not doserelated decreases in hematocrit values, hemoglobin concentrations, and/or erythrocyte counts, occurred in dosed female mice. These findings could suggest a minimal erythron effect in the females. However, the lack of a dose relationship and the minimal nature of the decreases make the toxicological significance of these findings questionable. There were no significant differences in sperm parameters of male mice or estrous cyclicity of female mice administered 90,180 , or $360 \mathrm{mg} / \mathrm{kg}$ when compared to the vehicle controls (Table E-3 and Table E-4). Female mice did exhibit a weak dose-related decrease in the proportion of females with regular cycles (vehicle controls, 9/10; $90 \mathrm{mg} / \mathrm{kg}, 10 / 10 ; 180 \mathrm{mg} / \mathrm{kg}, 8 / 10 ; 360 \mathrm{mg} / \mathrm{kg}, 6 / 10$ ); however, none of the dose groups were significantly different from the control group. This is not considered sufficient to indicate potential for reproductive toxicity.

Table 7. Survival and Body Weights of Mice in the Three-month Dermal Study of Sodium Thioglycolate $^{\mathrm{a}}$

\begin{tabular}{|c|c|c|c|c|c|}
\hline Dose (mg/kg) & Survival $^{\mathrm{b}}$ & $\begin{array}{c}\text { Initial Body } \\
\text { Weight (g) }\end{array}$ & $\begin{array}{l}\text { Final Body } \\
\text { Weight (g) }\end{array}$ & $\begin{array}{l}\text { Change in Body } \\
\text { Weight (g) }\end{array}$ & $\begin{array}{c}\text { Final Weight } \\
\text { Relative to } \\
\text { Controls (\%) }\end{array}$ \\
\hline \multicolumn{6}{|l|}{ Male } \\
\hline 0 & $10 / 10$ & $21.0 \pm 0.2$ & $29.0 \pm 0.5$ & $8.0 \pm 0.4$ & \\
\hline 22.5 & $10 / 10$ & $20.5 \pm 0.2$ & $28.2 \pm 0.3$ & $7.7 \pm 0.3$ & 97 \\
\hline 45 & $10 / 10$ & $21.0 \pm 0.2$ & $28.1 \pm 0.7$ & $7.1 \pm 0.7$ & 97 \\
\hline 90 & $10 / 10$ & $21.0 \pm 0.3$ & $28.2 \pm 0.6$ & $7.3 \pm 0.5$ & 97 \\
\hline 180 & $10 / 10$ & $20.6 \pm 0.3$ & $28.8 \pm 0.4$ & $8.2 \pm 0.3$ & 99 \\
\hline 360 & $10 / 10$ & $20.8 \pm 0.2$ & $28.3 \pm 0.3$ & $7.5 \pm 0.2$ & 98 \\
\hline \multicolumn{6}{|l|}{ Female } \\
\hline 0 & $10 / 10$ & $17.6 \pm 0.3$ & $24.4 \pm 0.5$ & $6.8 \pm 0.3$ & \\
\hline 22.5 & $10 / 10$ & $17.4 \pm 0.3$ & $24.8 \pm 0.4$ & $7.4 \pm 0.3$ & 102 \\
\hline 45 & $10 / 10$ & $17.5 \pm 0.3$ & $25.4 \pm 0.7$ & $8.0 \pm 0.7$ & 104 \\
\hline 90 & $10 / 10$ & $17.7 \pm 0.3$ & $24.6 \pm 0.5$ & $6.9 \pm 0.3$ & 101 \\
\hline 180 & $10 / 10$ & $17.7 \pm 0.3$ & $25.3 \pm 0.4$ & $7.6 \pm 0.3$ & 104 \\
\hline 360 & $10 / 10$ & $17.7 \pm 0.2$ & $25.5 \pm 0.4$ & $7.9 \pm 0.4$ & 105 \\
\hline
\end{tabular}

${ }^{a}$ Weights and weight changes are given as mean \pm standard error. Differences from the vehicle control group are not significant by Dunnett's test.

${ }^{b}$ Number of animals surviving at 3 months/number initially in group. 

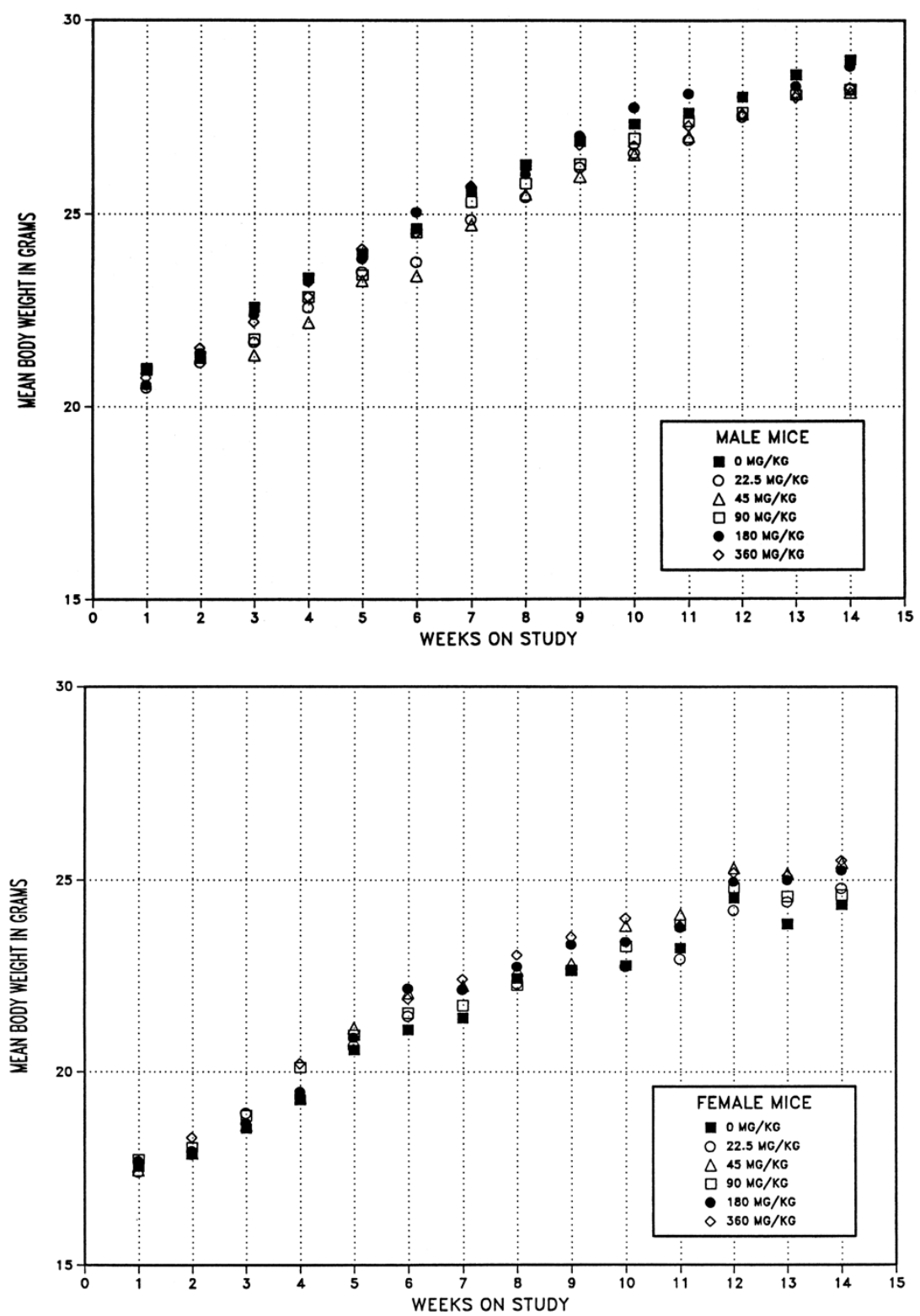

Figure 3. Growth Curves for Mice Administered Sodium Thioglycolate Dermally for Three Months 
Absolute heart weights were significantly increased in 180 and $360 \mathrm{mg} / \mathrm{kg}$ males and $45 \mathrm{mg} / \mathrm{kg}$ or greater females; relative heart weights were significantly increased in $22.5 \mathrm{mg} / \mathrm{kg}$ or greater males and $360 \mathrm{mg} / \mathrm{kg}$ females (Table 8 and Table D-4). Absolute liver weights were significantly increased in 180 and $360 \mathrm{mg} / \mathrm{kg}$ males and $22.5 \mathrm{mg} / \mathrm{kg}$ or greater females; relative liver weights were significantly increased in $90 \mathrm{mg} / \mathrm{kg}$ or greater males and $45 \mathrm{mg} / \mathrm{kg}$ or greater females. Absolute kidney weights were significantly increased in 180 and $360 \mathrm{mg} / \mathrm{kg}$ females. No histologic findings correlating with the significant organ weights changes were seen in the liver, heart, or kidneys.

Table 8. Selected Organ Weights and Organ-Weight-to-Body-Weight Ratios for Mice in the Three-month Dermal Study of Sodium Thioglycolate

\begin{tabular}{|c|c|c|c|c|c|c|}
\hline & $\begin{array}{l}\text { Vehicle } \\
\text { Control }\end{array}$ & $22.5 \mathrm{mg} / \mathrm{kg}$ & $45 \mathrm{mg} / \mathrm{kg}$ & $90 \mathrm{mg} / \mathrm{kg}$ & $180 \mathrm{mg} / \mathrm{kg}$ & $360 \mathrm{mg} / \mathrm{kg}$ \\
\hline n & 10 & 10 & 10 & 10 & 10 & 10 \\
\hline \multicolumn{7}{|l|}{ Male } \\
\hline $\begin{array}{l}\text { Necropsy } \\
\text { body wt }\end{array}$ & $29.0 \pm 0.5$ & $28.2 \pm 0.3$ & $28.1 \pm 0.7$ & $28.2 \pm 0.6$ & $28.8 \pm 0.4$ & $28.3 \pm 0.3$ \\
\hline \multicolumn{7}{|l|}{ Heart } \\
\hline Absolute & $0.137 \pm 0.002$ & $0.147 \pm 0.002$ & $0.147 \pm 0.004$ & $0.141 \pm 0.002$ & $0.148 \pm 0.002 *$ & $0.148 \pm 0.002^{*}$ \\
\hline Relative & $4.725 \pm 0.041$ & $5.196 \pm 0.087 * *$ & $5.213 \pm 0.087 * *$ & $5.018 \pm 0.110^{* *}$ & $5.141 \pm 0.067 * *$ & $5.247 \pm 0.080^{* *}$ \\
\hline \multicolumn{7}{|l|}{ Liver } \\
\hline Absolute & $1.300 \pm 0.022$ & $1.281 \pm 0.028$ & $1.251 \pm 0.023$ & $1.329 \pm 0.035$ & $1.404 \pm 0.025^{* *}$ & $1.409 \pm 0.025^{* *}$ \\
\hline Relative & $44.876 \pm 0.512$ & $45.361 \pm 0.801$ & $44.580 \pm 0.621$ & $47.151 \pm 0.851^{*}$ & $48.771 \pm 0.692 * *$ & $49.844 \pm 0.696 * *$ \\
\hline
\end{tabular}

Female

Necropsy body wt

$24.4 \pm 0.5$

$24.8 \pm 0.4$

$25.4 \pm 0.7$

$24.6 \pm 0.5$

$25.3 \pm 0.4$

$25.5 \pm 0.4$

Heart
Absolute
$0.124 \pm 0.003 \quad 0.131 \pm 0.003$
$0.134 \pm 0.002 *$
$0.129 \pm 0.002 *$
$0.134 \pm 0.003 * *$
$0.140 \pm 0.003 * *$
Relative
$5.074 \pm 0.097 \quad 5.278 \pm 0.094$
$5.300 \pm 0.117$
$5.257 \pm 0.104$
$5.307 \pm 0.135$
$5.481 \pm 0.109^{*}$

R. Kidney
Absolute
$0.179 \pm 0.006 \quad 0.189 \pm 0.005$
$0.191 \pm 0.004$
$0.184 \pm 0.004$
$0.196 \pm 0.003^{*}$
$0.198 \pm 0.002 *$
Relative
$7.350 \pm 0.166$
$7.610 \pm 0.180$
$7.531 \pm 0.201$
$7.482 \pm 0.133$
$7.743 \pm 0.089$
$7.755 \pm 0.111$

Liver

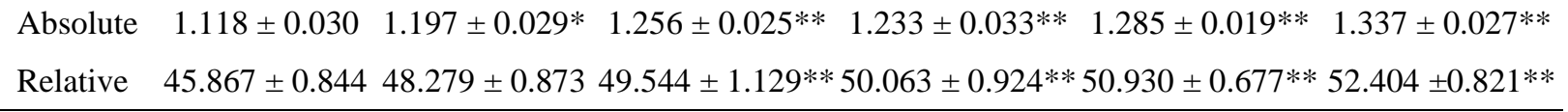
*Significantly different $(\mathrm{P} \leq 0.05)$ from the vehicle control group by Williams' or Dunnett's test.

$* * \mathrm{P} \leq 0.01$.

${ }^{\text {a } O r g a n ~ w e i g h t s ~(a b s o l u t e ~ w e i g h t s) ~ a n d ~ b o d y ~ w e i g h t s ~ a r e ~ g i v e n ~ i n ~ g r a m s ; ~ o r g a n-w e i g h t-t o-b o d y-w e i g h t ~ r a t i o s ~(r e l a t i v e ~ w e i g h t s) ~}$ are given as $\mathrm{mg}$ organ weight/g body weight (mean \pm standard error).

No chemical-related gross lesions were observed at necropsy. Microscopically, nonneoplastic lesions were limited to the site of application (Table 9, Table A-3, and Table A-4). These observations included focal or diffuse epidermal hyperplasia (thickening), hyperkeratosis 
(thickening of the stratum corneum), and sebaceous gland hypertrophy (increase in the size of the cells) (Figure 6 and Figure 7). Most observations were minimal to mild and often difficult to distinguish from normal. The dose relation of the lesions was apparent only in the 180 and $360 \mathrm{mg} / \mathrm{kg}$ groups. The following severity criteria were applied to grade the epidermal hyperplasia: minimal hyperplasia was two to three cell layers thick; mild was four to six cell layers thick; moderate was seven to eight cell layers thick; and marked was equal to or greater than nine cell layers thick.

Table 9. Incidences of Nonneoplastic Lesions of the Skin at the Site of Application in Mice in the Three-month Dermal Study of Sodium Thioglycolate

\begin{tabular}{|c|c|c|c|c|c|c|}
\hline & $\begin{array}{l}\text { Vehicle } \\
\text { Control }\end{array}$ & $22.5 \mathrm{mg} / \mathrm{kg}$ & $45 \mathrm{mg} / \mathrm{kg}$ & $90 \mathrm{mg} / \mathrm{kg}$ & $180 \mathrm{mg} / \mathrm{kg}$ & $360 \mathrm{mg} / \mathrm{kg}$ \\
\hline \multicolumn{7}{|l|}{ Male } \\
\hline $\begin{array}{l}\text { Number Examined } \\
\text { Microscopically }\end{array}$ & 10 & 10 & 10 & 10 & 10 & 10 \\
\hline $\begin{array}{l}\text { Sebaceous Gland, } \\
\text { Dermis, Hypertrophy }{ }^{\mathrm{a}}\end{array}$ & 0 & 0 & 0 & 0 & $2(1.0)^{\mathrm{b}}$ & $4 *(1.0)$ \\
\hline $\begin{array}{l}\text { Epidermis, } \\
\text { Hyperkeratosis }\end{array}$ & 0 & 0 & 0 & 0 & $3(1.0)$ & $3(1.0)$ \\
\hline $\begin{array}{l}\text { Epidermis, Hyperplasia, } \\
\text { Diffuse }\end{array}$ & 0 & 0 & 0 & 0 & $3(1.0)$ & $6 * *(2.2)$ \\
\hline \multicolumn{7}{|l|}{ Female } \\
\hline $\begin{array}{l}\text { Number Examined } \\
\text { Microscopically }\end{array}$ & 10 & 10 & 10 & 10 & 10 & 10 \\
\hline $\begin{array}{l}\text { Sebaceous Gland, } \\
\text { Dermis, Hypertrophy }\end{array}$ & 0 & 0 & 0 & 0 & $6 * *(1.0)$ & $7 * *(1.0)$ \\
\hline $\begin{array}{l}\text { Epidermis, } \\
\text { Hyperkeratosis }\end{array}$ & 0 & 0 & 0 & $1(1.0)$ & $1(1.0)$ & $4 *(1.3)$ \\
\hline $\begin{array}{l}\text { Epidermis, Hyperplasia, } \\
\text { Diffuse }\end{array}$ & 0 & 0 & 0 & 0 & $6^{* *}(1.5)$ & $8 * *(1.5)$ \\
\hline $\begin{array}{l}\text { Epidermis, Hyperplasia, } \\
\text { Focal }\end{array}$ & 0 & $1(3.0)$ & $3(1.0)$ & $1(1.0)$ & $3(1.0)$ & $2(1.0)$ \\
\hline
\end{tabular}

\section{Genetic Toxicology}

Sodium thioglycolate (10 to 1,000 $\mu \mathrm{g}$ /plate) was not mutagenic in Salmonella typhimurium strains TA98, TA100, TA1535, or TA1537 when tested with or without rat or hamster liver S9 activation enzymes (Table B-1; Zeiger et al. ${ }^{27}$ ). Dermal exposure to sodium thioglycolate for 3 months resulted in a small but significant $(P=0.002)$ increase in the frequency of micronucleated normochromatic erythrocytes in peripheral blood of female mice but not male mice (Table B-2). All dosed groups of male and female mice showed higher frequencies of micronucleated normochromatic erythrocytes compared to the vehicle control groups, but only the mean value seen in female mice treated with the highest dose of sodium thioglycolate was significantly increased. No significant dose-related alterations in the percentage of polychromatic 
erythrocytes (immature erythrocytes) were noted in either male or female mice treated with sodium thioglycolate, indicating an absence of bone marrow toxicity.

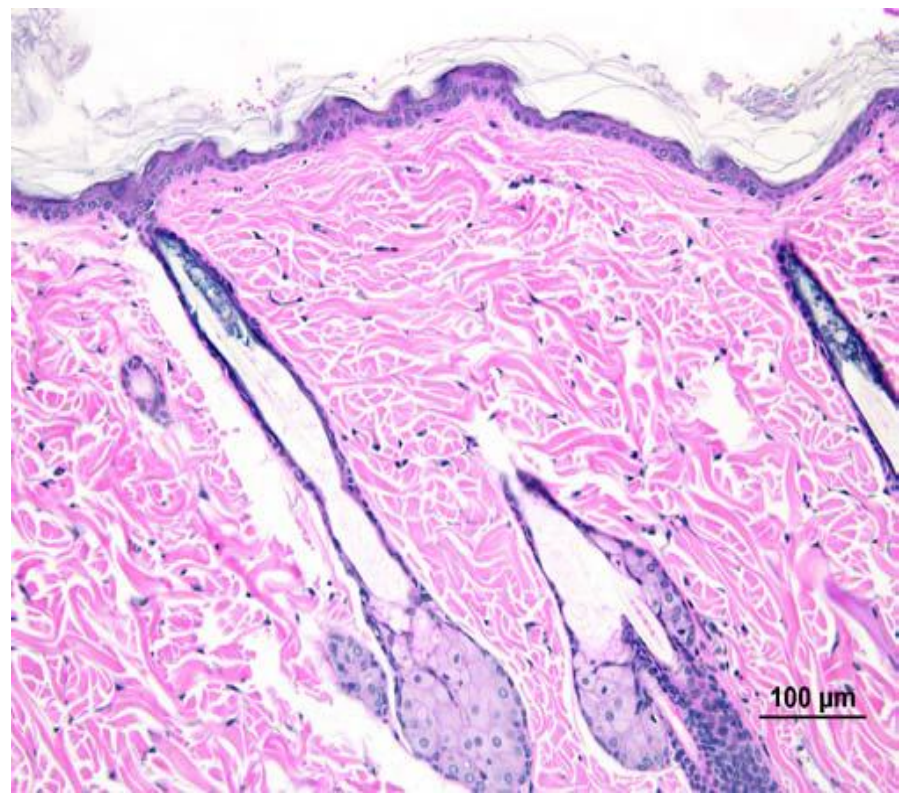

Figure 4. Normal Aspect of the Skin from a Vehicle Control Male Rat in the Three-month Dermal Study of Sodium Thioglycolate (H\&E)

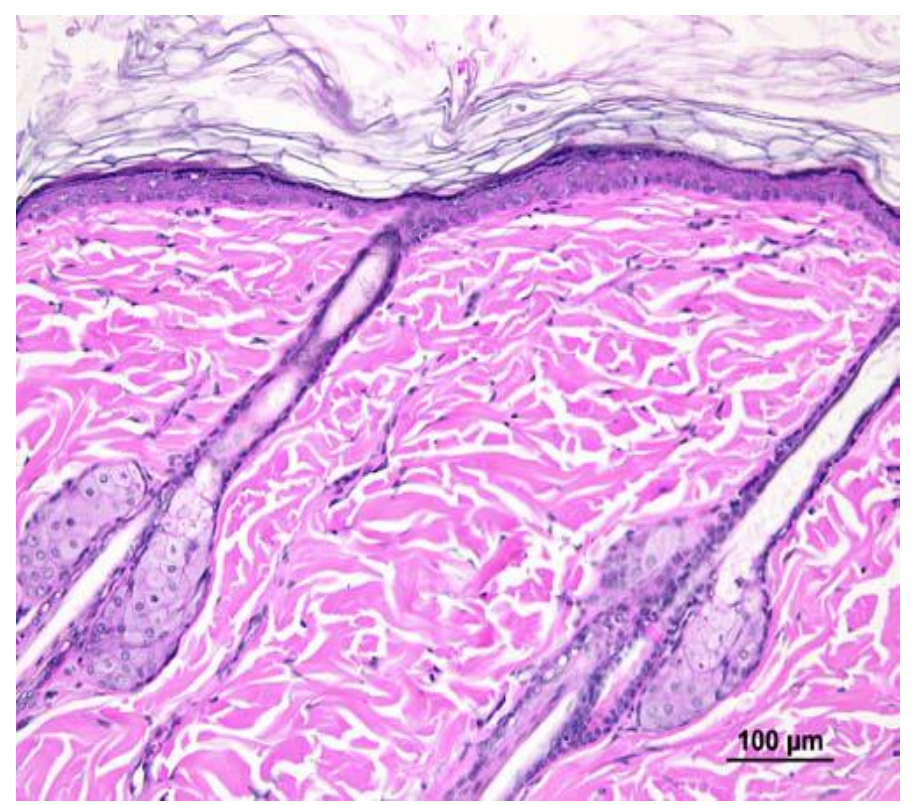

Figure 5. Diffuse, Minimal Epidermal Hyperplasia (Thickening) of the Skin of a Male Rat Dermally Administered $180 \mathrm{mg}$ Sodium Thioglycolate/kg Body Weight per Day for Three Months (H\&E) 


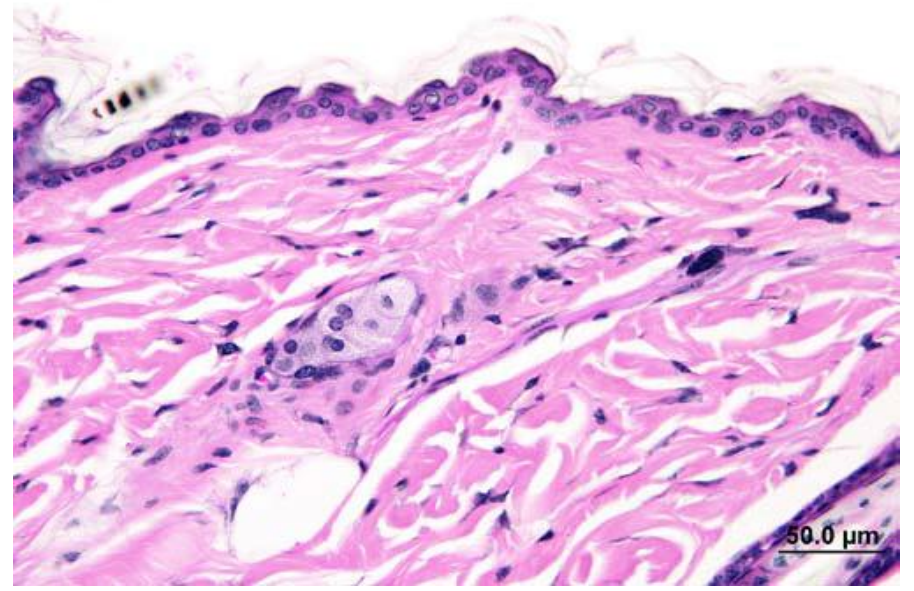

Figure 6. Normal Aspect of the Skin from a Vehicle Control Male Mouse in the Three-month Dermal Study of Sodium Thioglycolate (H\&E)

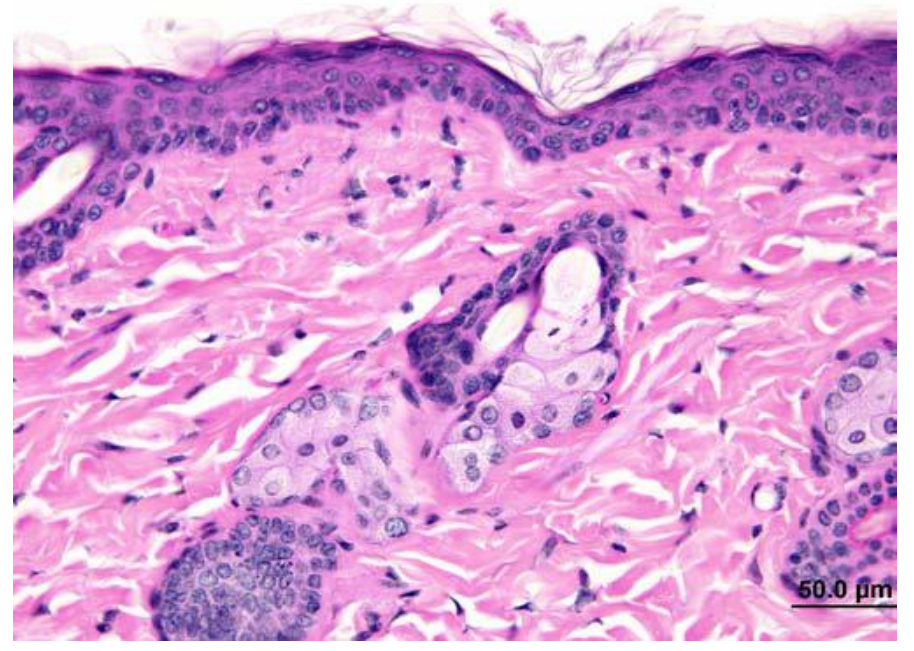

Figure 7. Diffuse, Mild Epidermal Hyperplasia (Thickening) of the Skin of a Male Mouse Dermally Administered $180 \mathrm{mg}$ Sodium Thioglycolate/kg Body Weight per Day for Three Months (H\&E) 


\section{Discussion}

Sodium thioglycolate is one of the salts of thioglycolic acid commonly used in consumer products to wave, straighten, or remove hair, and it may remain applied to the scalp or skin for up to 1 hour ${ }^{15}$. Sodium thioglycolate is also commonly used as an analytical reagent in the preparation of cell culture media ${ }^{1-3}$. Workers may be exposed through inhalation of aerosols and dermal contact to sodium thioglycolate, especially when applying hair care products to customers. The general population may be exposed through similar routes as workers during home application of hair care products containing sodium thioglycolate.

Sodium thioglycolate was nominated by the National Cancer Institute due to widespread occupational and consumer exposure, most significantly to women through the use of personal care products. NTP studies in rats and mice were conducted using the dermal route because that is the most common exposure route in humans. Animals in the 2-week studies were treated with the highest feasible concentration of sodium thioglycolate based on solubility or toxicity data. Doses for the 3-month studies were selected based on the results of the 2-week studies in mice and rats that showed no systemic toxicity and minimal dermal toxicity at the site of application.

All rats and mice in the 2-week and 3-month studies survived to the end of the study, except for one $360 \mathrm{mg} / \mathrm{kg}$ female mouse in the 2 -week study. There were increases in kidney weights and decreases in lung weights in the 2-week rat study, but these effects were not observed in the 3-month rat study. Increased kidney and heart weights occurred in the 3-month mouse study, but treatment-related microscopic lesions did not occur in these organs. Liver weights were significantly increased in $180 \mathrm{mg} / \mathrm{kg}$ male rats and mild cytoplasmic focal vacuolization of the centrilobular hepatocytes occurred in all groups of dosed males in the 2-week study; no similar changes were observed in the 3-month study. Liver weight increases in the 3-month mouse study occurred without any observed microscopic changes.

Feed consumption and clinical chemistry parameters were measured in the 3-month studies based on the findings by others indicating that thioglycolates inhibit fatty acid oxidation and increase food consumption after intraperitoneal injection, especially when the animals are on a medium-to-high fat (above 13\%) diet ${ }^{18-20}$. Contrary to previous findings, in the current dermal studies sodium thioglycolate did not induce significant differences in feed consumption or clinical parameters compared to controls; only small changes in mean body weight (within $10 \%$ of controls) were observed. Fat content of the NTP-2000 diet used in these studies in $8 \%$.

Gross and nonneoplastic microscopic lesions were mostly limited to the site of application. All rats and six male mice administered $360 \mathrm{mg} / \mathrm{kg}$ sodium thioglycolate for 3 months developed irritation at the site of application. Minimal to mild epidermal hyperplasia occurred at the site of application in rats and mice administered the highest doses of sodium thioglycolate in the 2-week studies. In the 3-month rat and mouse studies, microscopic lesions of minimal to mild severity were observed in the epidermis at the site of application, including hyperkeratosis, hyperplasia, and ulcers. Microscopic lesions were detected at lower doses in 3-month male rats than in females; conversely, microscopic lesions were detected in the 3-month mouse study at lower doses in females than in males. 
The weak decreased trend in the proportion of female mice with regular cycles in female mice was not considered sufficient to indicate potential for reproductive toxicity because none of the sodium thioglycolate dose groups was significantly different from the vehicle control group.

Sodium thioglycolate was not mutagenic in any of the Salmonella typhimurium strains tested. In chromosomal damage studies in vivo, sodium thioglycolate induced a small but statistically significant increase in micronucleated erythrocytes in female mice following 3 months of dermal application. In contrast, no increases were observed in male mice, and no changes in the percentage of immature polychromatic erythrocytes among total erythrocytes were observed, suggesting no bone marrow toxicity from sodium thioglycolate administration. Although clearly positive results in rodent micronucleus studies are associated with an increased risk for carcinogenicity, weak responses or responses in only one sex are not predictive of carcinogenic potential $^{42}$.

In summary, sodium thioglycolate caused minimal to mild nonneoplastic lesions at the site of application in rats and mice after 3 months of exposure through the skin. The no-observed-effect level (NOEL) for site of application lesions in female rats was $11.25 \mathrm{mg} / \mathrm{kg}$. The NOEL for site of application lesions in male mice was $90 \mathrm{mg} / \mathrm{kg}$. There was no NOEL for male rats or female mice. 


\section{References}

1. Hawley's condensed chemical dictionary, 13th edition. Lewis R, editor. New York, NY: Van Nostrand Reinhold; 1997.

2. CTFA cosmetic ingredient handbook. Nikitakis J, editor. Washington, DC: The Cosmetic, Toiletry, and Fragrance Association, Inc; 1988.

3. The Merck Index. In: Budavari S, editor. The Merck Index. New Jersey, NJ: Whitehouse Station; 1996b. p. 1484.

4. The Merck Index. In: Budavari S, editor. The Merck Index. New Jersey, NJ: Whitehouse Station; 1996a. p. 1593.

5. United States Environmental Protection Agency (USEPA). Inventory Update Reporting (IUR): Non-confidential 2006 IUR company/chemical records. 2012.

https://www.epa.gov/oppt/iur/tools/data/index.html [Accessed: August 23, 2012]

6. Burnett CL, Bergfeld WF, Belsito DV, Klaassen CD, Marks JG, Shank RC, Slaga TJ, Snyder PW, Andersen FA. Final amended report on the safety assessment of ammonium thioglycolate, butyl thioglycolate, calcium thioglycolate, ethanolamine thioglycolate, ethyl thioglycolate, glyceryl thioglycolate, isooctyl thioglycolate, isopropyl thioglycolate, magnesium thioglycolate, methyl thioglycolate, potassium thioglycolate, sodium thioglycolate, and thioglycolic acid. Int $\mathbf{J}$ Toxicol. 2009; 28(4):68-133. http://dx.doi.org/10.1177/1091581809339890

7. Hazardous Substances Data Bank (HSDB). National Institutes for Occupational Safety and Health (NIOSH); 2002. https://toxnet.nlm.nih.gov/cgi-bin/sis/htmlgen?HSDB.

8. National Institute of Occupational Safety and Health (NIOSH). National Occupational Exposure Survey (1981-1983), unpublished provisional data as of July 1, 1990. Cincinnati, OH: NIOSH. 1990.

9. American Conference of Governmental Industrial Hygienists (ACGIH). 2011 TLVs ${ }^{\circledR}$ and BEIs ${ }^{\circledR}$ based on the documentation of the threshold limit values for chemical substances and physical agents \& biological exposure indices. Cincinnati, OH; 2011.

10. National Institute for Occupational Safety and Health (NIOSH). NIOSH recommendations for occupational safety and health. Cincinnati, OH: U.S. Department of Health and Human Services, Public Health Service, Centers for Disease Control, National Institute for Occupational Safety and Health; 1992. DHHS Publication No. 92-100.

11. Freeman M, Draize JH, Smith PK. Some aspects of the absorption, distribution and excretion of sodium thioglycolate. J Pharmacol Exp Ther. 1956; 118(3):304-308.

12. Bakshy S, Gershbein L. Metabolism of S35-labeled thioglycolate. Arch Int Pharmacodyn Ther. 1972; 197:5-13.

13. Gershbein LL. Percutaneous toxicity of thioglycolate mixtures in rabbits. J Pharm Sci. 1979; 68(10):1230-1235. http://dx.doi.org/10.1002/jps.2600681009 
14. Freeman M, Draize JH, Smith PK. Some aspects of the mechanism of toxicity of thioglycolate. J Pharmacol Exp Ther. 1956; 118(3):296-303.

15. Cosmetic Ingredient Review (CIR). Final report on the safety assessment of ammonium and glyceryl thioglycolates and thioglycolic acid. J Am Coll Toxicol. 1991; 10:135-192.

http://dx.doi.org/10.3109/10915819109078628

16. Registry of Toxic Effects of Chemical Substances (RTECS). Acetic acid, mercapto-, monosodium salt. 2003. https://www.cdc.gov/niosh/rtecs/ai757e20.html [Accessed: April 21, 2005]

17. Del Prete E, Lutz TA, Althaus J, Scharrer E. Inhibitors of fatty acid oxidation (mercaptoacetate, R-3-amino-4-trimethylaminobutyric acid) stimulate feeding in mice. Physiol Behav. 1998; 63(5):751-754. http://dx.doi.org/10.1016/S0031-9384(97)00527-1

18. Garosi VL, Nisoli E, Blundell JE, Carruba MO. Pharmacological antagonism of lipoprivic feeding induced by sodium mercaptoacetate. Eur J Pharmacol. 1995; 276(3):285-289. http://dx.doi.org/10.1016/0014-2999(95)00087-2

19. Singer-Koegler L, Magluyan P, Ritter S. The effects of low-, medium-, and high-fat diets on 2-deoxy-D-glucose-and mercaptoacetate-induced feeding. Physiol Behav. 1996; 60(1):321-323. http://dx.doi.org/10.1016/0031-9384(95)02142-6

20. Scharrer E, Langhans W. Control of food intake by fatty acid oxidation. Am J Physiol Regul Integr Comp Physiol. 1986; 250(6):R1003-R1006.

http://dx.doi.org/10.1152/ajpregu.1986.250.6.R1003

21. European Chemicals Agency (ECHA). 2012.

http://apps.echa.europa.eu/registered/data/dossiers/DISS-9ebe899b-ae90-534d-e04400144f67d031/AGGR-f4aaeb65-13fa-41c5-aed2-10df122546aa_DISS-9ebe899b-ae90-534de044-00144f67d031.html\#AGGR-f4aaeb65-13fa-41c5-aed2-10df122546aa [Accessed:

December 5, 2012]

22. Tyl R, Price C, Marr M, Myers C, van Birgelen A, Jahnke G. Developmental toxicity evaluation of sodium thioglycolate administered topically to Sprague-Dawley (CD) rats and New Zealand White rabbits. Birth Defects Res B: Dev Reprod Toxicol. 2003; 68(2):144-161. http://dx.doi.org/10.1002/bdrb.10001

23. Walker J. A personal communication (facsimile transmittal) from John Walker, Ph.D., M.P.H., Executive Director, TSCA Interagency Testing Committee, Environmental Protection Agency, Washington, DC, to Victor Fung, Ph.D., National Cancer Institute, Division of Cancer Biology, 6/8/95 (cited in Tyl et al. 2003). 1995.

24. Walker J. A personal communication (facsimile transmittal) from John Walker, Ph.D., M.P.H., Executive Director, TSCA Interagency Testing Committee, Environmental Protection Agency, Washington, DC, to Victor Fung, Ph.D., National Cancer Institute, Division of Cancer Biology, 4/26/95 (cited in Tyl et al. 2003). 1995. 
25. Stenbäck F, Rowland J, Russell L. Non-carcinogenicity of hair dyes: lifetime percutaneous applications in mice and rabbits. Food Cosmet Toxicol. 1977; 15(6):601-606.

http://dx.doi.org/10.1016/0015-6264(77)90076-1

26. Gocke E, King M-T, Eckhardt K, Wild D. Mutagenicity of cosmetics ingredients licensed by the European Communities. Mutat Res. 1981; 90(2):91-109. http://dx.doi.org/10.1016/0165$\underline{1218(81) 90072-0}$

27. Zeiger E, Anderson B, Haworth S, Lawlor T, Mortelmans K, Speck W. Salmonella mutagenicity tests: III. Results from the testing of 255 chemicals. Environ Mutagen. 1987; 9(Suppl. 9):1-60. http://dx.doi.org/10.1002/em.2860090602

28. Maronpot R, Boorman G. Interpretation of rodent hepatocellular proliferative alterations and hepatocellular tumors in chemical safety assessment. Toxicol Pathol. 1982; 10(2):71-78. http://dx.doi.org/10.1177/019262338201000210

29. Boorman GA, Montgomery CA, Jr., Eustis SL, Wolfe MJ, McConnell EE, Hardisty JF. Quality assurance in pathology for rodent carcinogenicity studies. In: Milman HA, Weisburger EK, editors. Handbook of Carcinogen Testing. Park Ridge, NJ: Noyes Publications; 1985. p. 345-357.

30. Gart JJ, Chu KC, Tarone RE. Statistical issues in interpretation of chronic bioassay tests for carcinogenicity. J Natl Cancer Inst. 1979; 62(4):957-974.

31. Dunnett CW. A multiple comparison procedure for comparing several treatments with a control. J Am Stat Assoc. 1955; 50(272):1096-1121. http://dx.doi.org/10.1080/01621459.1955.10501294

32. Williams D. The comparison of several dose levels with a zero dose control. Biometrics. 1972; 28(2):519-531. http://dx.doi.org/10.2307/2556164

33. Williams D. A test for differences between treatment means when several dose levels are compared with a zero dose control. Biometrics. 1971; 27(1):103-117.

http://dx.doi.org/10.2307/2528930

34. Shirley E. A non-parametric equivalent of Williams' test for contrasting increasing dose levels of a treatment. Biometrics. 1977; 33(2):386-389. http://dx.doi.org/10.2307/2529789

35. Williams D. A note on Shirley's nonparametric test for comparing several dose levels with a zero-dose control. Biometrics. 1986; 42(1):183-186. http://dx.doi.org/10.2307/2531254

36. Dunn OJ. Multiple comparisons using rank sums. Technometrics. 1964; 6(3):241-252. http://dx.doi.org/10.1080/00401706.1964.10490181

37. Jonckheere A. A distribution-free k-sample test against ordered alternatives. Biometrika. 1954; 41:133-145. http://dx.doi.org/10.1093/biomet/41.1-2.133

38. Dixon W, Massey F. Introduction to statistical analysis. New York, NY: McGraw Hill Book Company Inc; 1957. http://dx.doi.org/10.2307/2332898 
39. Girard D, Sager D. The use of Markov chains to detect subtle variation in reproductive cycling. Biometrics. 1987; 43(1):225-234. http://dx.doi.org/10.2307/2531963

40. Code of Federal Regulations (CFR). 21:Part 58.

41. MacGregor JT, Wehr CM, Henika PR, Shelby MD. The in vivo erythrocyte micronucleus test: Measurement at steady state increases assay efficiency and permits integration with toxicity studies. Fundam Appl Toxicol. 1990; 14(3):513-522. http://dx.doi.org/10.1016/02720590(90)90255-I

42. Witt KL, Knapton A, Wehr CM, Hook GJ, Mirsalis J, Shelby MD, MacGregor JT. Micronucleated erythrocyte frequency in peripheral blood of B6C3F1 mice from short-term, prechronic, and chronic studies of the NTP carcinogenesis bioassay program. Environ Mol Mutagen. 2000; 36(3):163-194. http://dx.doi.org/10.1002/1098-2280(2000)36:3<163::AIDEM1>3.0.CO;2-P

43. Sadtler Standard Spectra. IR Spectrum No. 7036. Philadelphia, PA: Sadtler Research Laboratories; 1970. 


\section{Appendix A. Summary of Neoplasms and Nonneoplastic Lesions in Rats and Mice}

\section{Tables}

Table A-1. Summary of the Incidence of Nonneoplastic Lesions in Male Rats in the

Three-month Dermal Study of Sodium Thioglycolate

Table A-2. Summary of the Incidence of Neoplasms and Nonneoplastic Lesions in

Female Rats in the Three-month Dermal Study of Sodium Thioglycolate

Table A-3. Summary of the Incidence of Nonneoplastic Lesions in Male Mice in the

Three-month Dermal Study of Sodium Thioglycolate

Table A-4. Summary of the Incidence of Nonneoplastic Lesions in Female Mice in the

Three-month Dermal Study of Sodium Thioglycolate 
Table A-1. Summary of the Incidence of Nonneoplastic Lesions in Male Rats in the Three-month Dermal Study of Sodium Thioglycolate ${ }^{a}$

\begin{tabular}{|c|c|c|c|c|c|c|}
\hline & $\begin{array}{l}\text { Vehicle } \\
\text { Control }\end{array}$ & $\begin{array}{c}11.25 \\
\mathrm{mg} / \mathrm{kg}\end{array}$ & $\begin{array}{c}22.5 \\
\mathrm{mg} / \mathrm{kg}\end{array}$ & $\begin{array}{c}45 \\
\mathrm{mg} / \mathrm{kg}\end{array}$ & $\begin{array}{c}90 \\
\mathrm{mg} / \mathrm{kg}\end{array}$ & $\begin{array}{c}180 \\
\mathrm{mg} / \mathrm{kg}\end{array}$ \\
\hline \multicolumn{7}{|l|}{ Disposition Summary } \\
\hline Animals initially in study & 10 & 10 & 10 & 10 & 10 & 10 \\
\hline \multicolumn{7}{|l|}{ Survivors } \\
\hline Terminal kill & 10 & 10 & 10 & 10 & 10 & 10 \\
\hline Animals examined microscopically & 10 & 10 & 10 & 10 & 10 & 10 \\
\hline \multicolumn{7}{|l|}{ Alimentary System } \\
\hline Liver & (10) & - & - & - & - & (10) \\
\hline Hepatodiaphragmatic nodule & - & - & - & - & - & $1(10 \%)$ \\
\hline \multicolumn{7}{|l|}{ Cardiovascular System } \\
\hline Heart & (10) & - & - & - & - & (10) \\
\hline Cardiomyopathy & $3(30 \%)$ & - & - & - & - & $1(10 \%)$ \\
\hline \multicolumn{7}{|l|}{ Endocrine System } \\
\hline Adrenal cortex & (10) & - & - & - & - & (10) \\
\hline $\begin{array}{l}\text { Zona fasciculata, vacuolization } \\
\text { cytoplasmic }\end{array}$ & $10(100 \%)$ & - & - & - & - & $10(100 \%)$ \\
\hline
\end{tabular}

\section{General Body System}

None

\section{Genital System}

None

\begin{tabular}{|c|c|c|c|c|c|c|}
\hline \multicolumn{7}{|l|}{ Hematopoietic System } \\
\hline Spleen & $(10)$ & - & - & - & - & $(10)$ \\
\hline Congestion & $9(90 \%)$ & - & - & - & - & $10(100 \%)$ \\
\hline Hematopoietic cell proliferation & $10(100 \%)$ & - & - & - & - & $10(100 \%)$ \\
\hline Pigmentation & $9(90 \%)$ & - & - & - & - & $10(100 \%)$ \\
\hline Thymus & $(10)$ & - & - & - & - & $(10)$ \\
\hline Hemorrhage, focal & $1(10 \%)$ & - & - & - & - & $1(10 \%)$ \\
\hline Thymocyte, atrophy & - & - & - & - & - & $1(10 \%)$ \\
\hline \multicolumn{7}{|l|}{ Integumentary System } \\
\hline Skin & $(10)$ & $(10)$ & $(10)$ & $(10)$ & $(10)$ & $(10)$ \\
\hline $\begin{array}{l}\text { Sebaceous gland, site of application, } \\
\text { dermis, hypertrophy }\end{array}$ & - & - & $2(20 \%)$ & $4(40 \%)$ & $5(50 \%)$ & $6(60 \%)$ \\
\hline $\begin{array}{l}\text { Site of application, epidermis, } \\
\text { exudate, focal }\end{array}$ & - & - & - & - & - & $1(10 \%)$ \\
\hline $\begin{array}{l}\text { Site of application, epidermis, } \\
\text { hyperkeratosis }\end{array}$ & - & $6(60 \%)$ & $9(90 \%)$ & $4(40 \%)$ & $4(40 \%)$ & $4(40 \%)$ \\
\hline $\begin{array}{l}\text { Site of application, epidermis, } \\
\text { hyperplasia, diffuse }\end{array}$ & - & $1(10 \%)$ & $2(20 \%)$ & $3(30 \%)$ & $5(50 \%)$ & $6(60 \%)$ \\
\hline
\end{tabular}


Sodium Thioglycolate, NTP TOX 80

\begin{tabular}{|c|c|c|c|c|c|c|}
\hline & $\begin{array}{l}\text { Vehicle } \\
\text { Control } \\
\end{array}$ & $\begin{array}{l}11.25 \\
\mathrm{mg} / \mathrm{kg}\end{array}$ & $\begin{array}{c}22.5 \\
\mathrm{mg} / \mathrm{kg}\end{array}$ & $\begin{array}{c}45 \\
\mathrm{mg} / \mathrm{kg}\end{array}$ & $\begin{array}{c}90 \\
\mathrm{mg} / \mathrm{kg}\end{array}$ & $\begin{array}{c}180 \\
\mathrm{mg} / \mathrm{kg}\end{array}$ \\
\hline $\begin{array}{l}\text { Site of application, epidermis, } \\
\text { hyperplasia, focal }\end{array}$ & - & - & - & - & $1(10 \%)$ & - \\
\hline $\begin{array}{l}\text { Site of application, epidermis, } \\
\text { parakeratosis, focal }\end{array}$ & $1(10 \%)$ & - & - & - & - & - \\
\hline \multicolumn{7}{|l|}{ Musculoskeletal System } \\
\hline None & - & - & - & - & - & - \\
\hline \multicolumn{7}{|l|}{ Nervous System } \\
\hline None & - & - & - & - & - & - \\
\hline \multicolumn{7}{|l|}{ Respiratory System } \\
\hline Lung & $(10)$ & - & - & - & - & $(10)$ \\
\hline Hemorrhage, focal & $1(10 \%)$ & - & - & - & - & - \\
\hline Alveolus, hemorrhage, focal & - & - & - & - & - & $1(10 \%)$ \\
\hline $\begin{array}{l}\text { Alveolus, infiltration cellular, } \\
\text { histiocyte }\end{array}$ & - & - & - & - & - & $1(10 \%)$ \\
\hline $\begin{array}{l}\text { Alveolus, inflammation, chronic } \\
\text { active, focal }\end{array}$ & $2(20 \%)$ & - & - & - & - & - \\
\hline \multicolumn{7}{|l|}{ Special Senses System } \\
\hline None & - & - & - & - & - & - \\
\hline \multicolumn{7}{|l|}{ Urinary System } \\
\hline Kidney & $(10)$ & - & - & - & - & $(10)$ \\
\hline Nephropathy & $3(30 \%)$ & - & - & - & - & - \\
\hline Nephropathy, focal & - & - & - & - & - & $1(10 \%)$ \\
\hline Renal tubule, regeneration, focal & $1(10 \%)$ & - & - & - & - & $2(20 \%)$ \\
\hline
\end{tabular}

${ }^{\mathrm{a}}$ Number of animals examined microscopically at the site and the number of animals with lesions. 
Table A-2. Summary of the Incidence of Neoplasms and Nonneoplastic Lesions in Female Rats in the Three-month Dermal Study of Sodium Thioglycolate ${ }^{a}$

\begin{tabular}{|c|c|c|c|c|c|c|}
\hline & $\begin{array}{l}\text { Vehicle } \\
\text { Control }\end{array}$ & $\begin{array}{c}11.25 \\
\mathrm{mg} / \mathrm{kg}\end{array}$ & $\begin{array}{c}22.5 \\
\mathrm{mg} / \mathrm{kg}\end{array}$ & $\begin{array}{c}45 \\
\mathrm{mg} / \mathrm{kg}\end{array}$ & $\begin{array}{c}90 \\
\mathrm{mg} / \mathrm{kg}\end{array}$ & $\begin{array}{c}180 \\
\mathrm{mg} / \mathrm{kg}\end{array}$ \\
\hline \multicolumn{7}{|l|}{ Disposition Summary } \\
\hline Animals initially in study & 10 & 10 & 10 & 10 & 10 & 10 \\
\hline \multicolumn{7}{|l|}{ Survivors } \\
\hline Terminal kill & 10 & 10 & 10 & 10 & 10 & 10 \\
\hline Animals examined microscopically & 10 & 10 & 10 & 10 & 10 & 10 \\
\hline \multicolumn{7}{|l|}{ Alimentary System } \\
\hline Liver & (10) & - & - & - & - & $(10)$ \\
\hline Hepatodiaphragmatic nodule & - & - & - & - & - & $2(20 \%)$ \\
\hline Inflammation, granulomatous & $1(10 \%)$ & - & - & - & - & $3(30 \%)$ \\
\hline Necrosis, focal & $1(10 \%)$ & - & - & - & - & - \\
\hline Pancreas & $(10)$ & - & - & - & - & $(10)$ \\
\hline Atrophy, focal & $1(10 \%)$ & - & - & - & - & - \\
\hline \multicolumn{7}{|l|}{ Cardiovascular System } \\
\hline Heart & (10) & - & - & - & - & (10) \\
\hline Cardiomyopathy & $1(10 \%)$ & - & - & - & - & - \\
\hline \multicolumn{7}{|l|}{ Endocrine System } \\
\hline Pituitary gland & (10) & - & - & - & - & $(10)$ \\
\hline Cyst & - & - & - & - & - & $1(10 \%)$ \\
\hline Thyroid gland & (9) & - & - & - & - & (9) \\
\hline Ectopic thymus & $1(11 \%)$ & - & - & - & - & $2(22 \%)$ \\
\hline \multicolumn{7}{|l|}{ General Body System } \\
\hline None & - & - & - & - & - & - \\
\hline \multicolumn{7}{|l|}{ Genital System } \\
\hline Uterus & $(10)$ & - & - & - & - & $(10)$ \\
\hline Dilatation & $2(20 \%)$ & - & - & - & - & $4(40 \%)$ \\
\hline \multicolumn{7}{|l|}{ Hematopoietic System } \\
\hline Lymph node & (1) & - & - & - & - & (3) \\
\hline Hemorrhage & - & - & - & - & - & $1(33 \%)$ \\
\hline $\begin{array}{l}\text { Pancreatic, inflammation, } \\
\text { granulomatous }\end{array}$ & $1(100 \%)$ & - & - & - & - & - \\
\hline Thoracic, hyperplasia, lymphoid & - & - & - & - & - & $2(67 \%)$ \\
\hline Lymph node, mesenteric & $(10)$ & - & - & - & - & $(10)$ \\
\hline Inflammation, granulomatous & - & - & - & - & - & $1(10 \%)$ \\
\hline
\end{tabular}


Sodium Thioglycolate, NTP TOX 80

\begin{tabular}{|c|c|c|c|c|c|c|}
\hline & $\begin{array}{l}\text { Vehicle } \\
\text { Control }\end{array}$ & $\begin{array}{l}11.25 \\
\mathrm{mg} / \mathrm{kg}\end{array}$ & $\begin{array}{c}22.5 \\
\mathrm{mg} / \mathrm{kg}\end{array}$ & $\begin{array}{c}45 \\
\mathrm{mg} / \mathrm{kg}\end{array}$ & $\begin{array}{c}90 \\
\mathrm{mg} / \mathrm{kg}\end{array}$ & $\begin{array}{c}180 \\
\mathrm{mg} / \mathrm{kg}\end{array}$ \\
\hline Spleen & $(10)$ & - & - & - & - & (10) \\
\hline Congestion & $10(100 \%)$ & - & - & - & - & $10(100 \%)$ \\
\hline Hematopoietic cell proliferation & $10(100 \%)$ & - & - & - & - & $10(100 \%)$ \\
\hline Pigmentation & $9(90 \%)$ & - & - & - & - & $10(100 \%)$ \\
\hline Thymus & (10) & - & - & - & - & (10) \\
\hline Thymocyte, atrophy & $4(40 \%)$ & - & - & - & - & $3(30 \%)$ \\
\hline \multicolumn{7}{|l|}{ Integumentary System } \\
\hline Skin & (10) & (10) & (10) & $(10)$ & $(10)$ & $(10)$ \\
\hline $\begin{array}{l}\text { Sebaceous gland, site of } \\
\text { application, dermis, hypertrophy }\end{array}$ & - & - & - & $2(20 \%)$ & $6(60 \%)$ & $5(50 \%)$ \\
\hline $\begin{array}{l}\text { Site of application, epidermis, } \\
\text { hyperkeratosis }\end{array}$ & - & - & $1(10 \%)$ & $7(70 \%)$ & $6(60 \%)$ & $5(50 \%)$ \\
\hline $\begin{array}{l}\text { Site of application, epidermis, } \\
\text { hyperplasia, diffuse }\end{array}$ & - & - & - & $2(20 \%)$ & $7(70 \%)$ & $8(80 \%)$ \\
\hline $\begin{array}{l}\text { Site of application, epidermis, } \\
\text { infiltration cellular, mononuclear } \\
\text { cell }\end{array}$ & - & - & - & - & $1(10 \%)$ & - \\
\hline $\begin{array}{l}\text { Site of application, epidermis, } \\
\text { parakeratosis, focal }\end{array}$ & - & - & - & - & - & $3(30 \%)$ \\
\hline $\begin{array}{l}\text { Site of application, epidermis, ulcer, } \\
\text { focal }\end{array}$ & - & - & - & - & - & $3(30 \%)$ \\
\hline \multicolumn{7}{|l|}{ Musculoskeletal System } \\
\hline None & - & - & - & - & - & - \\
\hline
\end{tabular}

Nervous System

None

Respiratory System

None

Special Senses System

Harderian gland

$\begin{array}{lllll}- & - & - & - & -\end{array}$

Infiltration cellular, lymphocyte

$-$

$-$

$-$

$1(10 \%)$

\section{Urinary System}

Kidney

$-$

Nephroblastoma

$1(10 \%)$

Renal tubule, regeneration, focal

${ }^{\mathrm{a}}$ Number of animals examined microscopically at the site and the number of animals with lesion 
Table A-3. Summary of the Incidence of Nonneoplastic Lesions in Male Mice in the Three-month Dermal Study of Sodium Thioglycolate ${ }^{a}$

\begin{tabular}{|c|c|c|c|c|c|c|}
\hline & $\begin{array}{l}\text { Vehicle } \\
\text { Control }\end{array}$ & $22.5 \mathrm{mg} / \mathrm{kg}$ & $45 \mathrm{mg} / \mathrm{kg}$ & $90 \mathrm{mg} / \mathrm{kg}$ & $180 \mathrm{mg} / \mathrm{kg}$ & $360 \mathrm{mg} / \mathrm{kg}$ \\
\hline \multicolumn{7}{|l|}{ Disposition Summary } \\
\hline Animals initially in study & 10 & 10 & 10 & 10 & 10 & 10 \\
\hline \multicolumn{7}{|l|}{ Survivors } \\
\hline Terminal kill & 10 & 10 & 10 & 10 & 10 & 10 \\
\hline Animals examined microscopically & 10 & 10 & 10 & 10 & 10 & 10 \\
\hline \multicolumn{7}{|l|}{ Alimentary System } \\
\hline Liver & $(10)$ & - & - & - & - & $(10)$ \\
\hline Inflammation, chronic active & $1(10 \%)$ & - & - & - & - & - \\
\hline \multicolumn{7}{|l|}{ Cardiovascular System } \\
\hline None & - & - & - & - & - & - \\
\hline \multicolumn{7}{|l|}{ Endocrine System } \\
\hline Adrenal cortex & $(10)$ & - & - & - & - & $(10)$ \\
\hline Subcapsular, hyperplasia & $2(20 \%)$ & - & - & - & - & $3(30 \%)$ \\
\hline Thyroid gland & (9) & - & - & - & - & (9) \\
\hline Ectopic thymus & - & - & - & - & - & $1(11 \%)$ \\
\hline \multicolumn{7}{|l|}{ General Body System } \\
\hline None & - & - & - & - & - & - \\
\hline \multicolumn{7}{|l|}{ Genital System } \\
\hline None & - & - & - & - & - & - \\
\hline \multicolumn{7}{|l|}{ Hematopoietic System } \\
\hline Spleen & $(10)$ & - & - & - & - & $(10)$ \\
\hline Hematopoietic cell proliferation & $10(100 \%)$ & - & - & - & - & $10(100 \%)$ \\
\hline Thymus & (7) & - & - & - & - & $(10)$ \\
\hline Thymocyte, atrophy & $1(14 \%)$ & - & - & - & - & - \\
\hline \multicolumn{7}{|l|}{ Integumentary System } \\
\hline Skin & $(10)$ & (10) & (10) & (10) & (10) & (10) \\
\hline $\begin{array}{l}\text { Sebaceous gland, site of application, } \\
\text { dermis, hypertrophy }\end{array}$ & - & - & - & - & $2(20 \%)$ & $4(40 \%)$ \\
\hline $\begin{array}{l}\text { Site of application, epidermis, } \\
\text { hyperkeratosis }\end{array}$ & - & - & - & - & $3(30 \%)$ & $3(30 \%)$ \\
\hline $\begin{array}{l}\text { Site of application, epidermis, } \\
\text { hyperplasia, diffuse }\end{array}$ & - & - & - & - & $3(30 \%)$ & $6(60 \%)$ \\
\hline $\begin{array}{l}\text { Site of application, epidermis, } \\
\text { hyperplasia, focal }\end{array}$ & - & - & $1(10 \%)$ & - & $2(20 \%)$ & $1(10 \%)$ \\
\hline
\end{tabular}


Sodium Thioglycolate, NTP TOX 80

\begin{tabular}{|c|c|c|c|c|c|c|}
\hline & $\begin{array}{l}\text { Vehicle } \\
\text { Control }\end{array}$ & $22.5 \mathrm{mg} / \mathrm{kg}$ & $45 \mathrm{mg} / \mathrm{kg}$ & $90 \mathrm{mg} / \mathrm{kg}$ & $180 \mathrm{mg} / \mathrm{kg}$ & $360 \mathrm{mg} / \mathrm{kg}$ \\
\hline \multicolumn{7}{|l|}{ Musculoskeletal System } \\
\hline None & - & - & - & - & - & - \\
\hline \multicolumn{7}{|l|}{ Nervous System } \\
\hline None & - & - & - & - & - & - \\
\hline \multicolumn{7}{|l|}{ Respiratory System } \\
\hline None & - & - & - & - & - & - \\
\hline \multicolumn{7}{|l|}{ Special Senses System } \\
\hline None & - & - & - & - & - & - \\
\hline \multicolumn{7}{|l|}{ Urinary System } \\
\hline Kidney & $(10)$ & - & - & - & - & $(10)$ \\
\hline Renal tubule, regeneration & - & - & - & - & - & $2(20 \%)$ \\
\hline
\end{tabular}


Table A-4. Summary of the Incidence of Nonneoplastic Lesions in Female Mice in the Three-month Dermal Study of Sodium Thioglycolate ${ }^{a}$

\begin{tabular}{|c|c|c|c|c|c|c|}
\hline & $\begin{array}{l}\text { Vehicle } \\
\text { Control }\end{array}$ & $22.5 \mathrm{mg} / \mathrm{kg}$ & $45 \mathrm{mg} / \mathrm{kg}$ & $90 \mathrm{mg} / \mathrm{kg}$ & $180 \mathrm{mg} / \mathrm{kg}$ & $360 \mathrm{mg} / \mathrm{kg}$ \\
\hline \multicolumn{7}{|l|}{ Disposition Summary } \\
\hline Animals initially in study & 10 & 10 & 10 & 10 & 10 & 10 \\
\hline \multicolumn{7}{|l|}{ Survivors } \\
\hline Terminal kill & 10 & 10 & 10 & 10 & 10 & 10 \\
\hline Animals examined microscopically & 10 & 10 & 10 & 10 & 10 & 10 \\
\hline \multicolumn{7}{|l|}{ Alimentary System } \\
\hline Liver & (10) & - & - & - & - & $(10)$ \\
\hline Inflammation, chronic active & $2(20 \%)$ & - & - & - & - & $5(50 \%)$ \\
\hline Necrosis, focal & - & - & - & - & - & $3(30 \%)$ \\
\hline \multicolumn{7}{|l|}{ Cardiovascular System } \\
\hline None & - & - & - & - & - & - \\
\hline \multicolumn{7}{|l|}{ Endocrine System } \\
\hline Adrenal cortex & $(10)$ & - & - & - & - & $(10)$ \\
\hline Subcapsular, hyperplasia & $10(100 \%)$ & - & - & - & - & $10(100 \%)$ \\
\hline Thyroid gland & $(10)$ & - & - & - & - & $(10)$ \\
\hline Ectopic thymus & - & - & - & - & - & $1(10 \%)$ \\
\hline \multicolumn{7}{|l|}{ General Body System } \\
\hline None & - & - & - & - & - & - \\
\hline \multicolumn{7}{|l|}{ Genital System } \\
\hline Oviduct & (1) & - & - & - & - & - \\
\hline Cyst & $1(100 \%)$ & - & - & - & - & - \\
\hline Uterus & $(10)$ & - & - & - & - & $(10)$ \\
\hline Endometrium, hyperplasia, cystic & $4(40 \%)$ & - & - & - & - & $4(40 \%)$ \\
\hline \multicolumn{7}{|l|}{ Hematopoietic System } \\
\hline Spleen & $(10)$ & - & - & - & - & $(10)$ \\
\hline Hematopoietic cell proliferation & $8(80 \%)$ & - & - & - & - & $10(100 \%)$ \\
\hline Thymus & $(10)$ & - & - & - & - & $(10)$ \\
\hline Thymocyte, atrophy & - & - & - & - & - & $1(10 \%)$ \\
\hline \multicolumn{7}{|l|}{ Integumentary System } \\
\hline Skin & (10) & $(10)$ & $(10)$ & $(10)$ & $(10)$ & $(10)$ \\
\hline $\begin{array}{l}\text { Sebaceous gland, site of application, } \\
\text { dermis, hypertrophy }\end{array}$ & - & - & - & - & $6(60 \%)$ & $7(70 \%)$ \\
\hline $\begin{array}{l}\text { Site of application, dermis, } \\
\text { hemorrhage, focal }\end{array}$ & - & $1(10 \%)$ & - & - & - & - \\
\hline $\begin{array}{l}\text { Site of application, dermis, } \\
\text { inflammation, chronic active }\end{array}$ & - & - & - & - & $1(10 \%)$ & - \\
\hline $\begin{array}{l}\text { Site of application, dermis, } \\
\text { inflammation, chronic active, focal }\end{array}$ & - & $1(10 \%)$ & - & $1(10 \%)$ & - & - \\
\hline
\end{tabular}


Sodium Thioglycolate, NTP TOX 80

\begin{tabular}{|c|c|c|c|c|c|c|}
\hline & $\begin{array}{l}\text { Vehicle } \\
\text { Control }\end{array}$ & $22.5 \mathrm{mg} / \mathrm{kg}$ & $45 \mathrm{mg} / \mathrm{kg}$ & $90 \mathrm{mg} / \mathrm{kg}$ & $180 \mathrm{mg} / \mathrm{kg}$ & $360 \mathrm{mg} / \mathrm{kg}$ \\
\hline $\begin{array}{l}\text { Site of application, epidermis, } \\
\text { exudate }\end{array}$ & - & $1(10 \%)$ & - & - & - & - \\
\hline $\begin{array}{l}\text { Site of application, epidermis, } \\
\text { exudate, focal }\end{array}$ & - & - & $1(10 \%)$ & - & - & - \\
\hline $\begin{array}{l}\text { Site of application, epidermis, } \\
\text { hyperkeratosis }\end{array}$ & - & - & - & $1(10 \%)$ & $1(10 \%)$ & $4(40 \%)$ \\
\hline $\begin{array}{l}\text { Site of application, epidermis, } \\
\text { hyperplasia, diffuse }\end{array}$ & - & - & - & - & $6(60 \%)$ & $8(80 \%)$ \\
\hline $\begin{array}{l}\text { Site of application, epidermis, } \\
\text { hyperplasia, focal }\end{array}$ & - & $1(10 \%)$ & $3(30 \%)$ & $1(10 \%)$ & $3(30 \%)$ & $2(20 \%)$ \\
\hline $\begin{array}{l}\text { Site of application, epidermis, } \\
\text { inflammation, chronic active }\end{array}$ & - & - & - & - & - & $1(10 \%)$ \\
\hline $\begin{array}{l}\text { Site of application, epidermis, } \\
\text { inflammation, chronic active, focal }\end{array}$ & - & - & $1(10 \%)$ & - & - & - \\
\hline \multicolumn{7}{|l|}{ Musculoskeletal System } \\
\hline None & - & - & - & - & - & - \\
\hline \multicolumn{7}{|l|}{ Nervous System } \\
\hline Brain & $(10)$ & - & - & - & - & $(10)$ \\
\hline Cyst epithelial inclusion & $1(10 \%)$ & - & - & - & - & - \\
\hline \multicolumn{7}{|l|}{ Respiratory System } \\
\hline None & - & - & - & - & - & - \\
\hline \multicolumn{7}{|l|}{ Special Senses System } \\
\hline None & - & - & - & - & - & - \\
\hline \multicolumn{7}{|l|}{ Urinary System } \\
\hline Kidney & $(10)$ & - & - & - & - & $(10)$ \\
\hline Inflammation, chronic active & - & - & - & - & - & $1(10 \%)$ \\
\hline Renal tubule, casts protein & - & - & - & - & - & $1(10 \%)$ \\
\hline Renal tubule, regeneration & - & - & - & - & - & $1(10 \%)$ \\
\hline
\end{tabular}




\section{Appendix B. Genetic Toxicology}

\section{Tables}

Table B-1. Mutagenicity of Sodium Thioglycolate in Salmonella typhimurium

Table B-2. Frequency of Micronuclei in Peripheral Blood Erythrocytes of Mice

Following Dermal Application of Sodium Thioglycolate for Three Months............. B-4 
Sodium Thioglycolate, NTP TOX 80

Table B-1. Mutagenicity of Sodium Thioglycolate in Salmonella typhimurium ${ }^{\text {a }}$

\begin{tabular}{|c|c|c|c|c|c|c|c|}
\hline Strain & $\begin{array}{c}\text { Dose } \\
(\mu \mathrm{g} / \text { plate })\end{array}$ & Without S9 & Without S9 & $\begin{array}{c}\text { With } 10 \% \\
\text { Hamster S9 }\end{array}$ & $\begin{array}{c}\text { With } 10 \% \\
\text { Hamster S9 }\end{array}$ & $\begin{array}{c}\text { With } 10 \% \\
\text { Rat S9 }\end{array}$ & $\begin{array}{c}\text { With } 10 \% \\
\text { Rat S9 }\end{array}$ \\
\hline \multicolumn{8}{|l|}{ TA100 } \\
\hline & 0 & $100 \pm 5$ & $110 \pm 6$ & $185 \pm 26$ & $179 \pm 12$ & $175 \pm 28$ & $189 \pm 9$ \\
\hline & 10 & $95 \pm 5$ & $126 \pm 11$ & $160 \pm 18$ & $164 \pm 6$ & $140 \pm 30$ & $204 \pm 38$ \\
\hline & 33 & $105 \pm 31$ & $129 \pm 8$ & $195 \pm 30$ & $174 \pm 8$ & $170 \pm 41$ & $189 \pm 4$ \\
\hline & 100 & $115 \pm 10$ & $121 \pm 4$ & $220 \pm 18$ & $221 \pm 4$ & $145 \pm 18$ & $175 \pm 9$ \\
\hline & 333 & $125 \pm 13$ & $122 \pm 8$ & $160 \pm 5$ & $173 \pm 10$ & $135 \pm 9$ & $221 \pm 8$ \\
\hline & 1,000 & $120 \pm 30$ & $124 \pm 9$ & $215 \pm 13$ & $202 \pm 4$ & $155 \pm 35$ & $181 \pm 18$ \\
\hline Trial summary & & Negative & Negative & Negative & Equivocal & Negative & Negative \\
\hline Positive control $^{\mathrm{b}}$ & & $430 \pm 28$ & $599 \pm 36$ & $558 \pm 6$ & $836 \pm 173$ & $300 \pm 11$ & $430 \pm 70$ \\
\hline \multicolumn{8}{|l|}{ TA1535 } \\
\hline & 0 & $7 \pm 1$ & $7 \pm 1$ & $6 \pm 1$ & $7 \pm 3$ & $7 \pm 1$ & \\
\hline & 10 & $6 \pm 1$ & $6 \pm 1$ & $5 \pm 1$ & $6 \pm 2$ & $8 \pm 1$ & \\
\hline & 33 & $5 \pm 1$ & $6 \pm 1$ & $7 \pm 2$ & $9 \pm 1$ & $6 \pm 1$ & \\
\hline & 100 & $8 \pm 4$ & $9 \pm 1$ & $7 \pm 1$ & $9 \pm 1$ & $6 \pm 1$ & \\
\hline & 333 & $6 \pm 1$ & $6 \pm 1$ & $5 \pm 1$ & $7 \pm 2$ & $8 \pm 1$ & \\
\hline & 1,000 & $5 \pm 1$ & $8 \pm 2$ & $5 \pm 0$ & $8 \pm 1$ & $8 \pm 1$ & \\
\hline Trial summary & & Negative & Negative & Negative & Negative & Negative & \\
\hline Positive control & & $288 \pm 32$ & $251 \pm 41$ & $106 \pm 16$ & $43 \pm 4$ & $135 \pm 10$ & \\
\hline \multicolumn{8}{|l|}{ TA1537 } \\
\hline & 0 & $6 \pm 3$ & $5 \pm 1$ & $8 \pm 1$ & $12 \pm 2$ & $5 \pm 1$ & $7 \pm 2$ \\
\hline & 10 & $7 \pm 1$ & $6 \pm 1$ & $4 \pm 1$ & $9 \pm 3$ & $4 \pm 1$ & $8 \pm 2$ \\
\hline & 33 & $6 \pm 1$ & $6 \pm 1$ & $6 \pm 0$ & $11 \pm 2$ & $8 \pm 2$ & $12 \pm 2$ \\
\hline & 100 & $5 \pm 1$ & $3 \pm 2$ & $5 \pm 1$ & $6 \pm 1$ & $6 \pm 2$ & $8 \pm 2$ \\
\hline & 333 & $6 \pm 1$ & $8 \pm 2$ & $6 \pm 1$ & $9 \pm 3$ & $5 \pm 1$ & $9 \pm 1$ \\
\hline & 1,000 & $7 \pm 2$ & $6 \pm 0$ & $6 \pm 0$ & $9 \pm 0$ & $6 \pm 1$ & $10 \pm 2$ \\
\hline Trial summary & & Negative & Negative & Negative & Negative & Negative & Negative \\
\hline Positive control & & $133 \pm 12$ & $248 \pm 79$ & $92 \pm 9$ & $48 \pm 7$ & $48 \pm 8$ & $60 \pm 29$ \\
\hline \multicolumn{8}{|l|}{ TA98 } \\
\hline & 0 & $17 \pm 2$ & $14 \pm 2$ & $22 \pm 2$ & $21 \pm 1$ & $18 \pm 2$ & $16 \pm 1$ \\
\hline & 10 & $17 \pm 2$ & $11 \pm 2$ & $25 \pm 2$ & $19 \pm 4$ & $27 \pm 5$ & $20 \pm 2$ \\
\hline & 33 & $21 \pm 2$ & $14 \pm 2$ & $23 \pm 2$ & $16 \pm 3$ & $15 \pm 3$ & $18 \pm 3$ \\
\hline & 100 & $21 \pm 3$ & $13 \pm 2$ & $18 \pm 2$ & $17 \pm 1$ & $18 \pm 3$ & $15 \pm 1$ \\
\hline & 333 & $20 \pm 2$ & $13 \pm 2$ & $23 \pm 2$ & $19 \pm 2$ & $19 \pm 3$ & $15 \pm 1$ \\
\hline & 1,000 & $22 \pm 3$ & $14 \pm 3$ & $18 \pm 3$ & $18 \pm 1$ & $16 \pm 1$ & $16 \pm 3$ \\
\hline
\end{tabular}


Sodium Thioglycolate, NTP TOX 80

\begin{tabular}{lccccccc}
\hline \multicolumn{1}{c}{ Strain } & $\begin{array}{c}\text { Dose } \\
(\boldsymbol{\mu g} / \text { plate })\end{array}$ & Without S9 & Without S9 & $\begin{array}{c}\text { With 10\% } \\
\text { Hamster S9 }\end{array}$ & $\begin{array}{c}\text { With 10\% } \\
\text { Hamster S9 }\end{array}$ & $\begin{array}{c}\text { With 10\% } \\
\text { Rat S9 }\end{array}$ & $\begin{array}{c}\text { With 10\% } \\
\text { Rat S9 }\end{array}$ \\
\hline Trial summary & & Negative & Negative & Negative & Negative & Negative & Negative \\
Positive control & & $246 \pm 23$ & $256 \pm 44$ & $468 \pm 16$ & $444 \pm 51$ & $142 \pm 23$ & $134 \pm 15$ \\
\hline
\end{tabular}

${ }^{\mathrm{a}}$ Data are presented as revertants/plate (mean \pm standard error) from three plates. Study was performed at Case Western Reserve University. The detailed protocol and these data are presented by Zeiger et al. ${ }^{27} .0 \mu \mathrm{g} / \mathrm{plate}$ was the solvent control.

${ }^{\mathrm{b}}$ The positive controls in the absence of metabolic activation were sodium azide (TA100 and TA1535), 9-aminoacridine (TA1537), and 4-nitro-o-phenylenediamine (TA98). The positive control for metabolic activation with all strains was 2aminoanthracene. 
Sodium Thioglycolate, NTP TOX 80

Table B-2. Frequency of Micronuclei in Peripheral Blood Erythrocytes of Mice Following Dermal Application of Sodium Thioglycolate for Three Months ${ }^{\mathrm{a}}$

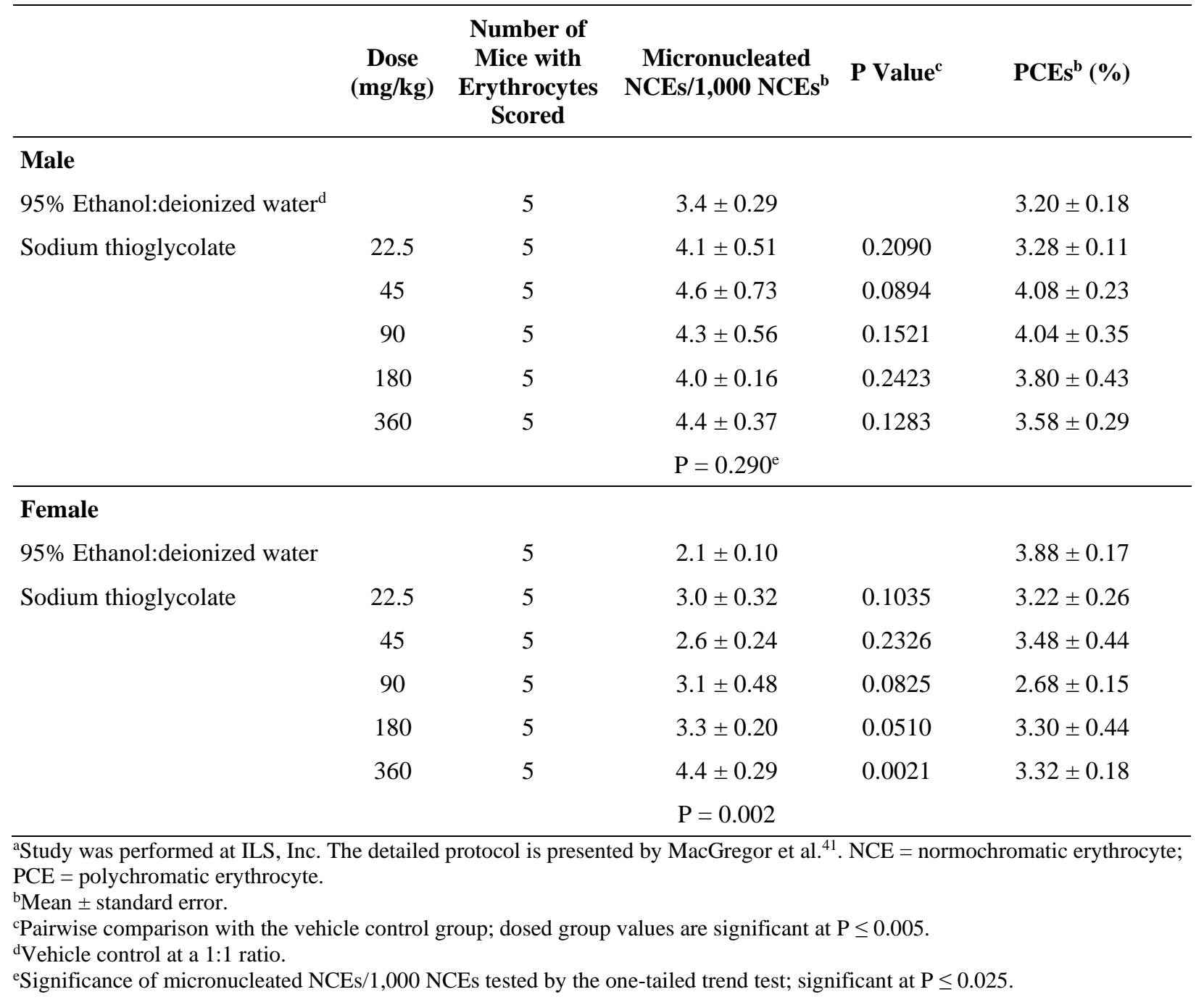




\section{Appendix C. Clinical Pathology Results}

\section{Tables}

Table C-1. Hematology and Clinical Chemistry Data for Rats in the Three-month Dermal Study of Sodium Thioglycolate .........................................................................

Table C-2. Hematology Data for Mice in the Three-month Dermal Study of Sodium Thioglycolate 
Table C-1. Hematology and Clinical Chemistry Data for Rats in the Three-month Dermal Study of Sodium Thioglycolate ${ }^{\mathrm{a}}$

\begin{tabular}{|c|c|c|c|c|c|c|}
\hline & $\begin{array}{l}\text { Vehicle } \\
\text { Control }\end{array}$ & $11.25 \mathrm{mg} / \mathrm{kg}$ & $22.5 \mathrm{mg} / \mathrm{kg}$ & $45 \mathrm{mg} / \mathrm{kg}$ & $90 \mathrm{mg} / \mathrm{kg}$ & $180 \mathrm{mg} / \mathrm{kg}$ \\
\hline \multicolumn{7}{|l|}{ Male } \\
\hline \multicolumn{7}{|c|}{ Hematology } \\
\hline \multicolumn{7}{|c|}{ n } \\
\hline Day 4 & 8 & 9 & 9 & 9 & 9 & 8 \\
\hline Day 22 & 9 & 10 & 10 & 10 & 10 & 10 \\
\hline Week 14 & 10 & 10 & 10 & 10 & 10 & 10 \\
\hline \multicolumn{7}{|c|}{ Hematocrit (\%) } \\
\hline Day 4 & $40.3 \pm 0.7$ & $40.8 \pm 0.5$ & $39.7 \pm 0.4$ & $39.7 \pm 0.6$ & $39.1 \pm 0.7$ & $41.0 \pm 0.8$ \\
\hline Day 22 & $45.6 \pm 1.2$ & $43.9 \pm 0.5$ & $44.1 \pm 0.9$ & $44.2 \pm 0.4$ & $44.6 \pm 0.6$ & $43.8 \pm 0.6$ \\
\hline Week 14 & $45.3 \pm 0.3$ & $45.1 \pm 0.6$ & $45.8 \pm 0.6$ & $44.6 \pm 0.6$ & $46.1 \pm 0.4$ & $45.4 \pm 0.4$ \\
\hline \multicolumn{7}{|c|}{ Hemoglobin (g/dL) } \\
\hline Day 4 & $13.4 \pm 0.2$ & $13.5 \pm 0.2$ & $13.2 \pm 0.1$ & $13.2 \pm 0.2$ & $13.0 \pm 0.2$ & $13.6 \pm 0.3$ \\
\hline Day 22 & $15.2 \pm 0.4$ & $14.6 \pm 0.2$ & $14.7 \pm 0.3$ & $14.7 \pm 0.1$ & $14.9 \pm 0.2$ & $14.6 \pm 0.2$ \\
\hline Week 14 & $15.7 \pm 0.1$ & $15.6 \pm 0.2$ & $15.8 \pm 0.2$ & $15.5 \pm 0.2$ & $15.9 \pm 0.2$ & $15.8 \pm 0.2$ \\
\hline \multicolumn{7}{|c|}{ Erythrocytes $\left(10^{6} / \mu \mathrm{L}\right)$} \\
\hline Day 4 & $6.79 \pm 0.12$ & $6.87 \pm 0.10$ & $6.70 \pm 0.06$ & $6.75 \pm 0.09$ & $6.62 \pm 0.13$ & $6.90 \pm 0.13$ \\
\hline Day 22 & $7.71 \pm 0.21$ & $7.42 \pm 0.09$ & $7.45 \pm 0.15$ & $7.45 \pm 0.08$ & $7.54 \pm 0.11$ & $7.38 \pm 0.10$ \\
\hline Week 14 & $9.13 \pm 0.06$ & $9.10 \pm 0.11$ & $9.19 \pm 0.12$ & $9.04 \pm 0.11$ & $9.26 \pm 0.08$ & $9.15 \pm 0.08$ \\
\hline \multicolumn{7}{|c|}{ Reticulocytes $\left(10^{6} / \mu \mathrm{L}\right)$} \\
\hline Day 4 & $0.47 \pm 0.02^{\mathrm{b}}$ & $0.54 \pm 0.02$ & $0.53 \pm 0.03$ & $0.53 \pm 0.02$ & $0.45 \pm 0.03$ & $0.53 \pm 0.02$ \\
\hline Day 22 & $0.30 \pm 0.03$ & $0.31 \pm 0.02$ & $0.28 \pm 0.02$ & $0.32 \pm 0.01$ & $0.30 \pm 0.01$ & $0.30 \pm 0.02$ \\
\hline Week 14 & $0.20 \pm 0.01$ & $0.22 \pm 0.02$ & $0.22 \pm 0.01$ & $0.21 \pm 0.01$ & $0.23 \pm 0.01$ & $0.21 \pm 0.01$ \\
\hline \multicolumn{7}{|c|}{ Mean cell volume (fL) } \\
\hline Day 4 & $59.3 \pm 0.3$ & $59.4 \pm 0.3$ & $59.2 \pm 0.3$ & $58.8 \pm 0.2$ & $59.1 \pm 0.2$ & $59.4 \pm 0.2$ \\
\hline Day 22 & $59.1 \pm 0.2$ & $59.2 \pm 0.2$ & $58.9 \pm 0.2$ & $59.3 \pm 0.2$ & $59.3 \pm 0.2$ & $59.3 \pm 0.2$ \\
\hline Week 14 & $49.7 \pm 0.2$ & $49.4 \pm 0.2$ & $49.9 \pm 0.2$ & $49.3 \pm 0.2$ & $50.0 \pm 0.2$ & $49.7 \pm 0.2$ \\
\hline \multicolumn{7}{|c|}{ Mean cell hemoglobin (pg) } \\
\hline Day 4 & $19.7 \pm 0.1$ & $19.7 \pm 0.1$ & $19.6 \pm 0.1$ & $19.6 \pm 0.1$ & $19.6 \pm 0.1$ & $19.7 \pm 0.1$ \\
\hline Day 22 & $19.7 \pm 0.1$ & $19.7 \pm 0.1$ & $19.7 \pm 0.1$ & $19.8 \pm 0.1$ & $19.7 \pm 0.1$ & $19.8 \pm 0.1$ \\
\hline Week 14 & $17.2 \pm 0.1$ & $17.2 \pm 0.1$ & $17.3 \pm 0.1$ & $17.1 \pm 0.1$ & $17.2 \pm 0.1$ & $17.2 \pm 0.1$ \\
\hline \multicolumn{7}{|c|}{ Mean cell hemoglobin concentration $(\mathrm{g} / \mathrm{dL})$} \\
\hline Day 4 & $33.3 \pm 0.0$ & $33.2 \pm 0.1$ & $33.2 \pm 0.1$ & $33.2 \pm 0.1$ & $33.3 \pm 0.1$ & $33.2 \pm 0.1$ \\
\hline Day 22 & $33.3 \pm 0.1$ & $33.3 \pm 0.1$ & $33.4 \pm 0.1$ & $33.4 \pm 0.1$ & $33.4 \pm 0.1$ & $33.3 \pm 0.1$ \\
\hline Week 14 & $34.5 \pm 0.1$ & $34.6 \pm 0.1$ & $34.6 \pm 0.1$ & $34.6 \pm 0.1$ & $34.5 \pm 0.1$ & $34.7 \pm 0.1$ \\
\hline
\end{tabular}


Sodium Thioglycolate, NTP TOX 80

\begin{tabular}{|c|c|c|c|c|c|c|}
\hline & $\begin{array}{l}\text { Vehicle } \\
\text { Control }\end{array}$ & $11.25 \mathrm{mg} / \mathrm{kg}$ & $22.5 \mathrm{mg} / \mathrm{kg}$ & $45 \mathrm{mg} / \mathrm{kg}$ & $90 \mathrm{mg} / \mathrm{kg}$ & $180 \mathrm{mg} / \mathrm{kg}$ \\
\hline \multicolumn{7}{|c|}{ Platelets $\left(10^{3} / \mu \mathrm{L}\right)$} \\
\hline Day 4 & $594.4 \pm 26.7$ & $560.0 \pm 39.8$ & $530.6 \pm 25.5$ & $591.0 \pm 15.2$ & $561.8 \pm 30.2$ & $569.5 \pm 29.0$ \\
\hline Day 22 & $522.4 \pm 36.5$ & $563.7 \pm 18.5$ & $534.1 \pm 31.0$ & $512.3 \pm 20.3$ & $545.3 \pm 14.1$ & $519.0 \pm 17.5$ \\
\hline Week 14 & $511.6 \pm 13.1$ & $503.6 \pm 12.8$ & $518.3 \pm 13.9$ & $525.5 \pm 12.2$ & $524.8 \pm 15.9$ & $502.9 \pm 13.8$ \\
\hline \multicolumn{7}{|c|}{ Leukocytes $\left(10^{3} / \mu \mathrm{L}\right)$} \\
\hline Day 4 & $10.61 \pm 0.63$ & $9.27 \pm 0.52$ & $10.13 \pm 0.43$ & $9.47 \pm 0.43$ & $10.33 \pm 0.67$ & $10.79 \pm 0.50$ \\
\hline Week 14 & $10.91 \pm 0.39$ & $11.08 \pm 0.38$ & $10.60 \pm 0.45$ & $10.99 \pm 0.51$ & $10.77 \pm 0.38$ & $9.75 \pm 0.41$ \\
\hline \multicolumn{7}{|c|}{ Segmented neutrophils $\left(10^{3} / \mu \mathrm{L}\right)$} \\
\hline Day 4 & $1.18 \pm 0.07$ & $1.03 \pm 0.08$ & $1.17 \pm 0.08$ & $1.05 \pm 0.05$ & $1.13 \pm 0.07$ & $1.33 \pm 0.19$ \\
\hline Week 14 & $2.88 \pm 0.18$ & $3.03 \pm 0.21$ & $2.57 \pm 0.22$ & $2.76 \pm 0.14$ & $2.98 \pm 0.14$ & $2.19 \pm 0.19$ \\
\hline \multicolumn{7}{|c|}{ Lymphocytes $\left(10^{3} / \mu \mathrm{L}\right)$} \\
\hline Day 4 & $8.55 \pm 0.51$ & $7.44 \pm 0.39$ & $8.01 \pm 0.42$ & $7.68 \pm 0.33$ & $8.33 \pm 0.54$ & $8.56 \pm 0.42$ \\
\hline Week 14 & $7.09 \pm 0.27$ & $6.87 \pm 0.34$ & $7.08 \pm 0.32$ & $7.20 \pm 0.39$ & $6.78 \pm 0.27$ & $6.77 \pm 0.33$ \\
\hline \multicolumn{7}{|c|}{ Monocytes $\left(10^{3} / \mu \mathrm{L}\right)$} \\
\hline Day 4 & $0.65 \pm 0.06$ & $0.58 \pm 0.05$ & $0.61 \pm 0.04$ & $0.55 \pm 0.06$ & $0.62 \pm 0.06$ & $0.69 \pm 0.03$ \\
\hline Week 14 & $0.59 \pm 0.05$ & $0.74 \pm 0.06$ & $0.60 \pm 0.05$ & $0.61 \pm 0.06$ & $0.61 \pm 0.06$ & $0.47 \pm 0.03$ \\
\hline \multicolumn{7}{|c|}{ Basophils $\left(10^{3} / \mu \mathrm{L}\right)$} \\
\hline Day 4 & $0.228 \pm 0.027$ & $0.189 \pm 0.018$ & $0.289 \pm 0.065$ & $0.183 \pm 0.021$ & $0.224 \pm 0.031$ & $0.20 \pm 0.023$ \\
\hline Week 14 & $0.228 \pm 0.026$ & $0.288 \pm 0.018$ & $0.222 \pm 0.022$ & $0.295 \pm 0.067$ & $0.259 \pm 0.032$ & $0.209 \pm 0.025$ \\
\hline \multicolumn{7}{|c|}{ Eosinophils $\left(10^{3} / \mu \mathrm{L}\right)$} \\
\hline Day 4 & $0.03 \pm 0.00$ & $0.02 \pm 0.00$ & $0.05 \pm 0.02$ & $0.03 \pm 0.00$ & $0.03 \pm 0.01$ & $0.03 \pm 0.00$ \\
\hline Week 14 & $0.12 \pm 0.01$ & $0.15 \pm 0.01$ & $0.12 \pm 0.01$ & $0.14 \pm 0.02$ & $0.13 \pm 0.02$ & $0.10 \pm 0.01$ \\
\hline
\end{tabular}

\section{Clinical Chemistry}

n

\begin{tabular}{llccccc} 
Day 4 & 10 & 10 & 9 & 10 & 10 & 10 \\
Day 22 & 10 & 10 & 10 & 10 & 10 & 10 \\
Week 14 & 10 & 10 & 10 & 10 & 9 & 10 \\
\hline
\end{tabular}

Urea nitrogen $(\mathrm{mg} / \mathrm{dL})$

\begin{tabular}{lcccccc} 
Day 4 & $14.5 \pm 0.7$ & $5.8 \pm 0.8$ & $15.1 \pm 0.6$ & $14.3 \pm 0.5$ & $14.3 \pm 0.4$ & $15.5 \pm 0.8$ \\
$\quad$ Day 22 & $16.9 \pm 0.6$ & $19.2 \pm 0.5^{*}$ & $17.8 \pm 0.4$ & $19.4 \pm 0.9^{*}$ & $17.8 \pm 0.6$ & $18.2 \pm 0.4$ \\
$\quad$ Week 14 & $17.6 \pm 1.0$ & $17.8 \pm 0.8$ & $18.0 \pm 1.1$ & $18.7 \pm 0.7$ & $18.2 \pm 0.8$ & $19.9 \pm 0.5^{* *}$ \\
$\quad$ Creatinine $(\mathrm{mg} / \mathrm{dL})$ & & & & & & \\
$\quad$ Day 4 & $0.27 \pm 0.02$ & $0.29 \pm 0.01$ & $0.29 \pm 0.01$ & $0.28 \pm 0.01$ & $0.28 \pm 0.01$ & $0.28 \pm 0.01$ \\
$\quad$ Day 22 & $0.32 \pm 0.01$ & $0.37 \pm 0.02$ & $0.32 \pm 0.01$ & $0.31 \pm 0.01$ & $0.32 \pm 0.01$ & $0.31 \pm 0.01$ \\
$\quad$ Week 14 & $0.40 \pm 0.02$ & $0.39 \pm 0.01$ & $0.41 \pm 0.01$ & $0.41 \pm 0.01$ & $0.41 \pm 0.01$ & $0.42 \pm 0.01$ \\
$\quad$ Total protein $(\mathrm{g} / \mathrm{dL})$ & & & & & & \\
$\quad$ Day 4 & $5.9 \pm 0.1$ & $5.9 \pm 0.1$ & $5.8 \pm 0.1$ & $5.8 \pm 0.1$ & $5.9 \pm 0.1$ & $5.9 \pm 0.1$ \\
\hline
\end{tabular}


Sodium Thioglycolate, NTP TOX 80

\begin{tabular}{|c|c|c|c|c|c|c|}
\hline & $\begin{array}{l}\text { Vehicle } \\
\text { Control }\end{array}$ & $11.25 \mathrm{mg} / \mathrm{kg}$ & $22.5 \mathrm{mg} / \mathrm{kg}$ & $45 \mathrm{mg} / \mathrm{kg}$ & $90 \mathrm{mg} / \mathrm{kg}$ & $180 \mathrm{mg} / \mathrm{kg}$ \\
\hline Day 22 & $6.4 \pm 0.1$ & $6.4 \pm 0.1$ & $6.2 \pm 0.1$ & $6.4 \pm 0.1$ & $6.4 \pm 0.1$ & $6.3 \pm 0.1$ \\
\hline Week 14 & $7.0 \pm 0.1$ & $7.2 \pm 0.1$ & $7.3 \pm 0.1$ & $7.3 \pm 0.1$ & $7.1 \pm 0.1$ & $7.3 \pm 0.1^{*}$ \\
\hline \multicolumn{7}{|c|}{ Albumin (g/dL) } \\
\hline Day 4 & $4.0 \pm 0.0$ & $4.1 \pm 0.0$ & $4.0 \pm 0.1$ & $4.0 \pm 0.1$ & $4.0 \pm 0.0$ & $4.0 \pm 0.1$ \\
\hline Day 22 & $4.3 \pm 0.1$ & $4.3 \pm 0.0$ & $4.2 \pm 0.0$ & $4.3 \pm 0.0$ & $4.3 \pm 0.0$ & $4.2 \pm 0.0$ \\
\hline Week 14 & $4.5 \pm 0.0$ & $4.6 \pm 0.0$ & $4.7 \pm 0.0^{*}$ & $4.6 \pm 0.0$ & $4.6 \pm 0.0$ & $4.7 \pm 0.0^{*}$ \\
\hline \multicolumn{7}{|c|}{ Globulin (g/dL) } \\
\hline Day 4 & $1.9 \pm 0.0$ & $1.9 \pm 0.0$ & $1.8 \pm 0.0$ & $1.8 \pm 0.0$ & $1.9 \pm 0.1$ & $1.8 \pm 0.0$ \\
\hline Day 22 & $2.1 \pm 0.0$ & $2.1 \pm 0.1$ & $2.0 \pm 0.1$ & $2.1 \pm 0.0$ & $2.1 \pm 0.1$ & $2.0 \pm 0.0$ \\
\hline Week 14 & $2.5 \pm 0.1$ & $2.6 \pm 0.1$ & $2.7 \pm 0.1$ & $2.7 \pm 0.0$ & $2.6 \pm 0.0$ & $2.7 \pm 0.0$ \\
\hline \multicolumn{7}{|c|}{ Albumin/globulin ratio } \\
\hline Day 4 & $2.1 \pm 0.0$ & $2.2 \pm 0.0$ & $2.2 \pm 0.0$ & $2.2 \pm 0.0$ & $2.2 \pm 0.0$ & $2.2 \pm 0.0$ \\
\hline Day 22 & $2.0 \pm 0.0$ & $2.1 \pm 0.0$ & $2.1 \pm 0.1$ & $2.1 \pm 0.0$ & $2.1 \pm 0.1$ & $2.1 \pm 0.0$ \\
\hline Week 14 & $1.8 \pm 0.0$ & $1.8 \pm 0.0$ & $1.8 \pm 0.0$ & $1.7 \pm 0.0$ & $1.8 \pm 0.0$ & $1.7 \pm 0.0$ \\
\hline \multicolumn{7}{|c|}{ Cholesterol (mg/dL) } \\
\hline Day 4 & $114 \pm 4$ & $113 \pm 3$ & $112 \pm 4$ & $113 \pm 3$ & $110 \pm 3$ & $107 \pm 4$ \\
\hline Day 22 & $98 \pm 3$ & $101 \pm 3$ & $97 \pm 3$ & $101 \pm 3$ & $100 \pm 2$ & $95 \pm 3$ \\
\hline Week 14 & $100 \pm 2$ & $105 \pm 2$ & $106 \pm 2$ & $107 \pm 2$ & $95 \pm 2$ & $106 \pm 2$ \\
\hline \multicolumn{7}{|c|}{ Alanine aminotransferase (IU/L) } \\
\hline Day 4 & $68 \pm 2$ & $66 \pm 1$ & $66 \pm 2$ & $65 \pm 1$ & $64 \pm 2$ & $66 \pm 1$ \\
\hline Day 22 & $64 \pm 2$ & $62 \pm 2$ & $60 \pm 1$ & $64 \pm 1$ & $63 \pm 2$ & $63 \pm 2$ \\
\hline Week 14 & $64 \pm 3$ & $74 \pm 5$ & $74 \pm 5$ & $76 \pm 4$ & $73 \pm 5$ & $76 \pm 3$ \\
\hline \multicolumn{7}{|c|}{ Alkaline phosphatase (IU/L) } \\
\hline Day 4 & $839 \pm 22$ & $841 \pm 13$ & $838 \pm 24$ & $824 \pm 18$ & $822 \pm 13$ & $808 \pm 28$ \\
\hline Day 22 & $598 \pm 23$ & $605 \pm 14$ & $590 \pm 14$ & $603 \pm 9$ & $611 \pm 9$ & $593 \pm 17$ \\
\hline Week 14 & $216 \pm 6$ & $222 \pm 7$ & $235 \pm 7$ & $237 \pm 3$ & $223 \pm 7$ & $227 \pm 5$ \\
\hline \multicolumn{7}{|c|}{ Creatine kinase (IU/L) } \\
\hline Day 4 & $306 \pm 52$ & $286 \pm 25$ & $515 \pm 110$ & $488 \pm 169$ & $381 \pm 61$ & $344 \pm 65$ \\
\hline Day 22 & $253 \pm 38^{\mathrm{c}}$ & $210 \pm 14$ & $230 \pm 21$ & $220 \pm 24$ & $190 \pm 18$ & $285 \pm 26$ \\
\hline Week 14 & $173 \pm 32$ & $301 \pm 49$ & $192 \pm 29$ & $217 \pm 25$ & $235 \pm 49$ & $233 \pm 31$ \\
\hline \multicolumn{7}{|c|}{ Sorbitol dehydrogenase (IU/L) } \\
\hline Day 4 & $11 \pm 1$ & $13 \pm 1$ & $12 \pm 1^{\mathrm{d}}$ & $11 \pm 1$ & $13 \pm 1$ & $13 \pm 1$ \\
\hline Day 22 & $14 \pm 1$ & $18 \pm 1$ & $17 \pm 1$ & $15 \pm 1$ & $15 \pm 1$ & $17 \pm 1$ \\
\hline Week 14 & $12 \pm 1$ & $12 \pm 1$ & $15 \pm 1$ & $16 \pm 1$ & $13 \pm 1$ & $16 \pm 1$ \\
\hline \multicolumn{7}{|c|}{ Bile acids $(\mu \mathrm{mol} / \mathrm{L})$} \\
\hline Day 4 & $35.2 \pm 4.5$ & $31.3 \pm 3.6$ & $34.6 \pm 2.4^{\mathrm{d}}$ & $34.0 \pm 4.1$ & $31.8 \pm 2.5$ & $40.6 \pm 2.8$ \\
\hline Day 22 & $34.7 \pm 4.0$ & $39.7 \pm 2.9$ & $30.2 \pm 2.7$ & $38.3 \pm 5.6$ & $34.3 \pm 2.2$ & $36.8 \pm 3.8$ \\
\hline
\end{tabular}


Sodium Thioglycolate, NTP TOX 80

\begin{tabular}{|c|c|c|c|c|c|c|}
\hline & $\begin{array}{l}\text { Vehicle } \\
\text { Control }\end{array}$ & $11.25 \mathrm{mg} / \mathrm{kg}$ & $22.5 \mathrm{mg} / \mathrm{kg}$ & $45 \mathrm{mg} / \mathrm{kg}$ & $90 \mathrm{mg} / \mathrm{kg}$ & $180 \mathrm{mg} / \mathrm{kg}$ \\
\hline Week 14 & $45.4 \pm 3.5$ & $46.7 \pm 6.7$ & $50.8 \pm 4.4$ & $45.8 \pm 3.8$ & $47.1 \pm 5.0$ & $50.1 \pm 4.2$ \\
\hline \multicolumn{7}{|c|}{ 3-Hydroxybutyrate $(\mu \mathrm{mol} / \mathrm{L})$} \\
\hline Day 4 & $106.6 \pm 12.5$ & $109.0 \pm 11.4$ & $121.1 \pm 11.1^{\mathrm{d}}$ & $148.1 \pm 15.3$ & $120.2 \pm 15.2$ & $126.4 \pm 14.3$ \\
\hline Day 22 & $126.3 \pm 31.4$ & $80.7 \pm 12.2$ & $60.2 \pm 6.9$ & $83.4 \pm 15.7$ & $118.3 \pm 45.0$ & $108.3 \pm 23.5$ \\
\hline Week 14 & $166.9 \pm 34.5$ & $153.8 \pm 36.7$ & $164.2 \pm 24.6$ & $70.7 \pm 7.0$ & $237.5 \pm 45.6$ & $110.6 \pm 24.9$ \\
\hline \multicolumn{7}{|c|}{ Free fatty acids $(\mathrm{mEq} / \mathrm{L})$} \\
\hline Day 4 & $0.529 \pm 0.021$ & $0.546 \pm 0.044$ & $0.471 \pm 0.039^{\mathrm{d}}$ & $0.492 \pm 0.024$ & $0.493 \pm 0.016$ & $0.507 \pm 0.032$ \\
\hline Day 22 & $0.449 \pm 0.041$ & $0.505 \pm 0.025$ & $0.440 \pm 0.039$ & $0.506 \pm 0.045$ & $0.495 \pm 0.055$ & $0.536 \pm 0.030$ \\
\hline Week 14 & $0.729 \pm 0.038$ & $0.854 \pm 0.099$ & $0.878 \pm 0.085$ & $0.779 \pm 0.074$ & $0.790 \pm 0.075$ & $0.781 \pm 0.073$ \\
\hline
\end{tabular}

\section{Female}

\section{Hematology}

n

\begin{tabular}{lcccccc} 
Day 4 & 10 & 10 & 10 & 10 & 10 & 10 \\
Day 22 & 10 & 10 & 10 & 9 & 10 & 10 \\
Week 14 & 10 & 9 & 10 & 10 & 10 & 10 \\
\hline
\end{tabular}

Hematocrit (\%)

Day 4

Day 22

$40.8 \pm 1.0$

$40.5 \pm 0.7$

$41.8 \pm 0.7$

$41.0 \pm 0.5$

$41.4 \pm 0.8$

$42.0 \pm 0.7$

Week 14

$45.9 \pm 0.4$

$45.5 \pm 0.4$

$46.7 \pm 1.3$

$45.0 \pm 0.4$

$46.3 \pm 0.3$

$45.7 \pm 0.5$

Hemoglobin (g/dL)

Day 4

$45.7 \pm 0.8$

$46.9 \pm 0.3$

$46.4 \pm 0.3$

$47.2 \pm 0.4$

$46.5 \pm 0.4$

$46.6 \pm 0.5$

Day 22

$13.9 \pm 0.3 \quad 13.8 \pm 0.2$

$14.2 \pm 0.2$

$13.9 \pm 0.2$

$14.1 \pm 0.3$

$14.2 \pm 0.2$

Week 14

$15.9 \pm 0.1$

$15.6 \pm 0.1$

$16.1 \pm 0.4$

$15.5 \pm 0.2$

$15.9 \pm 0.1$

$15.7 \pm 0.2$

$16.0 \pm 0.3 \quad 16.4 \pm 0.1$

$16.3 \pm 0.1$

$16.5 \pm 0.2$

$16.3 \pm 0.2$

$16.3 \pm 0.2$

Erythrocytes $\left(10^{6} / \mu \mathrm{L}\right)$

Day 4

$6.97 \pm 0.15$

$6.95 \pm 0.10$

$7.16 \pm 0.11$

$6.98 \pm 0.10$

$7.08 \pm 0.13$

$7.11 \pm 0.13$

Day 22

$7.91 \pm 0.08$

$7.83 \pm 0.07$

$8.08 \pm 0.21$

$7.73 \pm 0.09$

$7.92 \pm 0.06$

$7.79 \pm 0.09$

Week 14

$8.72 \pm 0.15$

$8.92 \pm 0.05$

$8.82 \pm 0.05$

$8.97 \pm 0.08$

$8.82 \pm 0.08$

$8.85 \pm 0.09$

Reticulocytes $\left(10^{6} / \mu \mathrm{L}\right)$

Day 4

$0.40 \pm 0.01$

$0.40 \pm 0.02$

$0.41 \pm 0.02$

$0.38 \pm 0.02$

$0.41 \pm 0.02$

$0.44 \pm 0.02$

Day 22

$0.23 \pm 0.01$

$0.21 \pm 0.01$

$0.19 \pm 0.01$

$0.22 \pm 0.01$

$0.19 \pm 0.01$

$0.20 \pm 0.01$

Week 14

$0.17 \pm 0.01$

$0.20 \pm 0.01$

$0.20 \pm 0.01$

$0.20 \pm 0.01$

$0.20 \pm 0.01$

$0.20 \pm 0.01$

Mean cell volume (fL)

Day 4

Day 22

Week 14
$58.6 \pm 0.2 \quad 58.2 \pm 0.2$

$52.4 \pm 0.2$

$58.2 \pm 0.2$

$52.6 \pm 0.2$

$58.3 \pm 0.3$

$58.8 \pm 0.2$

$58.5 \pm 0.2$

$58.9 \pm 0.2$

$57.7 \pm 0.2$

$58.2 \pm 0.2$

$58.3 \pm 0.3$

$58.7 \pm 0.3$

$52.7 \pm 0.2$

$52.6 \pm 0.2$

$52.8 \pm 0.1$

$52.5 \pm 0.2$

Mean cell hemoglobin (pg)

Day 4

$19.9 \pm 0.1$

$19.9 \pm 0.1$

$19.8 \pm 0.1$

$19.9 \pm 0.1$

$19.9 \pm 0.1$

$20.0 \pm 0.1$ 
Sodium Thioglycolate, NTP TOX 80

\begin{tabular}{|c|c|c|c|c|c|c|}
\hline & $\begin{array}{l}\text { Vehicle } \\
\text { Control }\end{array}$ & $11.25 \mathrm{mg} / \mathrm{kg}$ & $22.5 \mathrm{mg} / \mathrm{kg}$ & $45 \mathrm{mg} / \mathrm{kg}$ & $90 \mathrm{mg} / \mathrm{kg}$ & $180 \mathrm{mg} / \mathrm{kg}$ \\
\hline Day 22 & $20.1 \pm 0.1$ & $19.9 \pm 0.1$ & $19.9 \pm 0.1$ & $20.1 \pm 0.1$ & $20.0 \pm 0.1$ & $20.2 \pm 0.1$ \\
\hline Week 14 & $18.4 \pm 0.1$ & $18.4 \pm 0.0$ & $18.5 \pm 0.0$ & $18.4 \pm 0.0$ & $18.5 \pm 0.1$ & $18.5 \pm 0.0$ \\
\hline \multicolumn{7}{|c|}{ Mean cell hemoglobin concentration $(\mathrm{g} / \mathrm{dL})$} \\
\hline Day 4 & $34.1 \pm 0.1$ & $34.1 \pm 0.1$ & $33.9 \pm 0.1$ & $33.8 \pm 0.1$ & $34.1 \pm 0.1$ & $33.9 \pm 0.1$ \\
\hline Day 22 & $34.6 \pm 0.1$ & $34.3 \pm 0.1$ & $34.5 \pm 0.1$ & $34.5 \pm 0.1$ & $34.3 \pm 0.1$ & $34.4 \pm 0.1$ \\
\hline Week 14 & $35.2 \pm 0.2$ & $35.1 \pm 0.1$ & $35.1 \pm 0.1$ & $35.1 \pm 0.1$ & $35.1 \pm 0.1$ & $35.1 \pm 0.1$ \\
\hline \multicolumn{7}{|c|}{ Platelets $\left(10^{3} / \mu \mathrm{L}\right)$} \\
\hline Day 4 & $572.6 \pm 22.5$ & $521.4 \pm 24.1$ & $545.3 \pm 14.9$ & $559.7 \pm 11.4$ & $555.3 \pm 14.8$ & $562.5 \pm 23.1$ \\
\hline Day 22 & $510.5 \pm 20.1$ & $482.2 \pm 19.1$ & $465.2 \pm 28.6$ & $487.3 \pm 20.4$ & $485.4 \pm 23.5$ & $448.3 \pm 26.4$ \\
\hline Week 14 & $522.6 \pm 23.9$ & $503.6 \pm 21.3$ & $506.3 \pm 18.5$ & $552.5 \pm 11.9$ & $520.6 \pm 14.6$ & $551.2 \pm 10.5$ \\
\hline \multicolumn{7}{|c|}{ Leukocytes $\left(10^{3} / \mu \mathrm{L}\right)$} \\
\hline Day 4 & $9.58 \pm 0.50$ & $10.09 \pm 0.65$ & $9.93 \pm 0.48$ & $11.31 \pm 0.73$ & $9.94 \pm 0.70$ & $11.33 \pm 0.39$ \\
\hline Day 22 & $10.96 \pm 0.73$ & $11.70 \pm 0.91$ & $11.03 \pm 0.64$ & $11.37 \pm 0.39$ & $10.14 \pm 0.47$ & $11.41 \pm 0.91$ \\
\hline Week 14 & $6.94 \pm 0.52$ & $7.11 \pm 0.65$ & $8.17 \pm 0.48$ & $7.10 \pm 0.62$ & $7.38 \pm 0.64$ & $5.72 \pm 0.43$ \\
\hline \multicolumn{7}{|c|}{ Segmented neutrophils $\left(10^{3} / \mu \mathrm{L}\right)$} \\
\hline Day 4 & $1.02 \pm 0.05$ & $1.04 \pm 0.08$ & $0.97 \pm 0.04$ & $1.23 \pm 0.07$ & $1.06 \pm 0.11$ & $1.06 \pm 0.06$ \\
\hline Day 22 & $1.04 \pm 0.06$ & $1.09 \pm 0.08$ & $1.07 \pm 0.06$ & $1.12 \pm 0.08$ & $1.13 \pm 0.10$ & $1.22 \pm 0.20$ \\
\hline Week 14 & $1.83 \pm 0.19$ & $1.66 \pm 0.17$ & $2.13 \pm 0.20$ & $1.83 \pm 0.16$ & $1.84 \pm 0.16$ & $1.30 \pm 0.13$ \\
\hline \multicolumn{7}{|c|}{ Lymphocytes $\left(10^{3} / \mu \mathrm{L}\right)$} \\
\hline Day 4 & $7.65 \pm 0.42$ & $8.15 \pm 0.58$ & $8.14 \pm 0.40$ & $9.06 \pm 0.56$ & $7.92 \pm 0.49$ & $9.31 \pm 0.40$ \\
\hline Day 22 & $9.06 \pm 0.63$ & $9.48 \pm 0.72$ & $9.03 \pm 0.60$ & $9.40 \pm 0.30$ & $8.19 \pm 0.37$ & $9.22 \pm 0.71$ \\
\hline Week 14 & $4.53 \pm 0.30$ & $4.88 \pm 0.47$ & $5.39 \pm 0.26$ & $4.65 \pm 0.45$ & $4.96 \pm 0.45$ & $3.98 \pm 0.27$ \\
\hline \multicolumn{7}{|c|}{ Monocytes $\left(10^{3} / \mu \mathrm{L}\right)$} \\
\hline Day 4 & $0.55 \pm 0.04$ & $0.61 \pm 0.05$ & $0.62 \pm 0.05$ & $0.71 \pm 0.09$ & $0.66 \pm 0.07$ & $0.71 \pm 0.04$ \\
\hline Day 22 & $0.60 \pm 0.06$ & $0.79 \pm 0.11$ & $0.65 \pm 0.05$ & $0.55 \pm 0.04$ & $0.57 \pm 0.05$ & $0.59 \pm 0.06$ \\
\hline Week 14 & $0.36 \pm 0.05$ & $0.37 \pm 0.05$ & $0.44 \pm 0.05$ & $0.40 \pm 0.06$ & $0.37 \pm 0.05$ & $0.26 \pm 0.04$ \\
\hline \multicolumn{7}{|c|}{ Basophils $\left(10^{3} / \mu \mathrm{L}\right)$} \\
\hline Day 4 & $0.296 \pm 0.087$ & $0.267 \pm 0.041$ & $0.184 \pm 0.017$ & $0.286 \pm 0.050$ & $0.259 \pm 0.051$ & $0.214 \pm 0.010$ \\
\hline Day 22 & $0.212 \pm 0.025$ & $0.299 \pm 0.060$ & $0.217 \pm 0.013$ & $0.251 \pm 0.029$ & $0.208 \pm 0.017$ & $0.333 \pm 0.096$ \\
\hline Week 14 & $0.134 \pm 0.015$ & $0.122 \pm 0.012$ & $0.129 \pm 0.013$ & $0.129 \pm 0.014$ & $0.118 \pm 0.017$ & $0.095 \pm 0.009$ \\
\hline \multicolumn{7}{|c|}{ Eosinophils $\left(10^{3} / \mu \mathrm{L}\right)$} \\
\hline Day 4 & $0.05 \pm 0.01$ & $0.04 \pm 0.00$ & $0.03 \pm 0.01$ & $0.03 \pm 0.01$ & $0.05 \pm 0.02$ & $0.03 \pm 0.01$ \\
\hline Day 22 & $0.05 \pm 0.01$ & $0.04 \pm 0.01$ & $0.05 \pm 0.01$ & $0.05 \pm 0.01$ & $0.05 \pm 0.00$ & $0.05 \pm 0.01$ \\
\hline Week 14 & $0.07 \pm 0.01$ & $0.06 \pm 0.01$ & $0.08 \pm 0.01$ & $0.08 \pm 0.01$ & $0.09 \pm 0.02$ & $0.07 \pm 0.01$ \\
\hline
\end{tabular}


Sodium Thioglycolate, NTP TOX 80

\begin{tabular}{|c|c|c|c|c|c|c|}
\hline & $\begin{array}{l}\text { Vehicle } \\
\text { Control }\end{array}$ & $11.25 \mathrm{mg} / \mathrm{kg}$ & $22.5 \mathrm{mg} / \mathrm{kg}$ & $45 \mathrm{mg} / \mathrm{kg}$ & $90 \mathrm{mg} / \mathrm{kg}$ & $180 \mathrm{mg} / \mathrm{kg}$ \\
\hline \multicolumn{7}{|c|}{ Clinical Chemistry } \\
\hline $\mathbf{n}$ & 10 & 10 & 10 & 10 & 10 & 10 \\
\hline \multicolumn{7}{|c|}{ Urea nitrogen $(\mathrm{mg} / \mathrm{dL})$} \\
\hline Day 4 & $17.6 \pm 0.8$ & $16.9 \pm 0.5$ & $16.2 \pm 0.4$ & $15.8 \pm 0.7$ & $16.4 \pm 0.7$ & $15.7 \pm 0.5$ \\
\hline Day 22 & $21.5 \pm 0.6$ & $21.1 \pm 0.5$ & $21.3 \pm 0.8$ & $20.6 \pm 0.9$ & $20.8 \pm 1.0$ & $22.4 \pm 0.5$ \\
\hline Week 14 & $18.5 \pm 0.9$ & $18.1 \pm 0.7$ & $19.8 \pm 0.7$ & $18.5 \pm 0.5$ & $20.1 \pm 0.5$ & $21.1 \pm 0.7 *$ \\
\hline \multicolumn{7}{|c|}{ Creatinine (mg/dL) } \\
\hline Day 4 & $0.32 \pm 0.01$ & $0.31 \pm 0.02$ & $0.31 \pm 0.01$ & $0.28 \pm 0.01$ & $0.29 \pm 0.01$ & $0.32 \pm 0.02$ \\
\hline Day 22 & $0.36 \pm 0.02$ & $0.34 \pm 0.02$ & $0.34 \pm 0.02$ & $0.31 \pm 0.01$ & $0.36 \pm 0.02$ & $0.30 \pm 0.00^{*}$ \\
\hline Week 14 & $0.39 \pm 0.02$ & $0.42 \pm 0.02$ & $0.37 \pm 0.02$ & $0.38 \pm 0.01$ & $0.40 \pm 0.02$ & $0.40 \pm 0.02$ \\
\hline \multicolumn{7}{|c|}{ Total protein $(\mathrm{g} / \mathrm{dL})$} \\
\hline Day 4 & $6.1 \pm 0.1$ & $6.1 \pm 0.1$ & $6.2 \pm 0.1$ & $6.2 \pm 0.1$ & $6.2 \pm 0.1$ & $6.2 \pm 0.1$ \\
\hline Day 22 & $6.6 \pm 0.1$ & $6.2 \pm 0.1$ & $6.5 \pm 0.1$ & $6.3 \pm 0.1$ & $6.5 \pm 0.1$ & $6.6 \pm 0.1$ \\
\hline Week 14 & $6.6 \pm 0.1$ & $6.8 \pm 0.1$ & $6.8 \pm 0.1$ & $6.7 \pm 0.1$ & $6.7 \pm 0.1$ & $6.8 \pm 0.1$ \\
\hline \multicolumn{7}{|c|}{ Albumin (g/dL) } \\
\hline Day 4 & $4.2 \pm 0.1$ & $4.2 \pm 0.1$ & $4.3 \pm 0.1$ & $4.3 \pm 0.1$ & $4.3 \pm 0.1$ & $4.4 \pm 0.1$ \\
\hline Day 22 & $4.6 \pm 0.1$ & $4.4 \pm 0.1$ & $4.6 \pm 0.1$ & $4.5 \pm 0.0$ & $4.6 \pm 0.0$ & $4.7 \pm 0.1$ \\
\hline Week 14 & $4.5 \pm 0.1$ & $4.6 \pm 0.1$ & $4.7 \pm 0.1$ & $4.6 \pm 0.1$ & $4.6 \pm 0.0$ & $4.6 \pm 0.0$ \\
\hline \multicolumn{7}{|c|}{ Globulin (g/dL) } \\
\hline Day 4 & $1.8 \pm 0.0$ & $1.8 \pm 0.0$ & $1.9 \pm 0.0$ & $1.9 \pm 0.0$ & $1.9 \pm 0.1$ & $1.9 \pm 0.0$ \\
\hline Day 22 & $1.9 \pm 0.1$ & $1.8 \pm 0.1$ & $1.9 \pm 0.0$ & $1.8 \pm 0.0^{*}$ & $1.9 \pm 0.0$ & $1.9 \pm 0.0$ \\
\hline Week 14 & $2.1 \pm 0.1$ & $2.2 \pm 0.0$ & $2.1 \pm 0.1$ & $2.1 \pm 0.0$ & $2.1 \pm 0.0$ & $2.2 \pm 0.0$ \\
\hline \multicolumn{7}{|c|}{ Albumin/globulin ratio } \\
\hline Day 4 & $2.3 \pm 0.0$ & $2.3 \pm 0.0$ & $2.3 \pm 0.0$ & $2.4 \pm 0.1$ & $2.2 \pm 0.1$ & $2.3 \pm 0.0$ \\
\hline Day 22 & $2.5 \pm 0.1$ & $2.5 \pm 0.1$ & $2.5 \pm 0.1$ & $2.5 \pm 0.0$ & $2.5 \pm 0.1$ & $2.5 \pm 0.1$ \\
\hline Week 14 & $2.2 \pm 0.1$ & $2.2 \pm 0.0$ & $2.2 \pm 0.0$ & $2.2 \pm 0.0$ & $2.2 \pm 0.0$ & $2.1 \pm 0.0$ \\
\hline \multicolumn{7}{|c|}{ Cholesterol (mg/dL) } \\
\hline Day 4 & $109 \pm 4$ & $110 \pm 5$ & $108 \pm 3$ & $118 \pm 3$ & $112 \pm 4$ & $113 \pm 3$ \\
\hline Day 22 & $99 \pm 3$ & $94 \pm 3$ & $98 \pm 2$ & $93 \pm 2$ & $97 \pm 2$ & $92 \pm 5$ \\
\hline Week 14 & $96 \pm 2$ & $101 \pm 2$ & $104 \pm 3$ & $103 \pm 3$ & $96 \pm 3$ & $98 \pm 3$ \\
\hline \multicolumn{7}{|c|}{ Alanine aminotransferase (IU/L) } \\
\hline Day 4 & $52 \pm 2$ & $51 \pm 2$ & $54 \pm 2$ & $54 \pm 1$ & $56 \pm 2$ & $59 \pm 2$ \\
\hline Day 22 & $48 \pm 1$ & $49 \pm 2$ & $47 \pm 3$ & $46 \pm 1$ & $50 \pm 2$ & $52 \pm 4$ \\
\hline Week 14 & $67 \pm 10$ & $79 \pm 5$ & $66 \pm 5$ & $70 \pm 5$ & $74 \pm 4$ & $78 \pm 5$ \\
\hline \multicolumn{7}{|c|}{ Alkaline phosphatase (IU/L) } \\
\hline Day 4 & $708 \pm 16$ & $690 \pm 22$ & $713 \pm 19$ & $717 \pm 11$ & $684 \pm 17$ & $689 \pm 19$ \\
\hline Day 22 & $500 \pm 12$ & $487 \pm 11$ & $499 \pm 12$ & $499 \pm 11$ & $516 \pm 10$ & $481 \pm 19$ \\
\hline
\end{tabular}


Sodium Thioglycolate, NTP TOX 80

\begin{tabular}{|c|c|c|c|c|c|c|}
\hline & $\begin{array}{l}\text { Vehicle } \\
\text { Control }\end{array}$ & $11.25 \mathrm{mg} / \mathrm{kg}$ & $22.5 \mathrm{mg} / \mathrm{kg}$ & $45 \mathrm{mg} / \mathrm{kg}$ & $90 \mathrm{mg} / \mathrm{kg}$ & $180 \mathrm{mg} / \mathrm{kg}$ \\
\hline Week 14 & $201 \pm 6$ & $193 \pm 5$ & $217 \pm 11$ & $197 \pm 5$ & $216 \pm 7$ & $204 \pm 8$ \\
\hline \multicolumn{7}{|c|}{ Creatine kinase (IU/L) } \\
\hline Day 4 & $215 \pm 29^{c}$ & $268 \pm 38$ & $251 \pm 35$ & $192 \pm 15$ & $292 \pm 63$ & $191 \pm 24$ \\
\hline Day 22 & $192 \pm 18^{c}$ & $273 \pm 52$ & $213 \pm 33$ & $304 \pm 55$ & $236 \pm 23$ & $200 \pm 22$ \\
\hline Week 14 & $139 \pm 14$ & $233 \pm 74$ & $161 \pm 21$ & $129 \pm 14$ & $222 \pm 36$ & $205 \pm 40$ \\
\hline \multicolumn{7}{|c|}{ Sorbitol dehydrogenase (IU/L) } \\
\hline Day 4 & $15 \pm 1$ & $15 \pm 1$ & $15 \pm 1$ & $16 \pm 1$ & $15 \pm 1$ & $16 \pm 1$ \\
\hline Day 22 & $17 \pm 1$ & $17 \pm 1$ & $19 \pm 2$ & $17 \pm 1$ & $20 \pm 1$ & $18 \pm 1$ \\
\hline Week 14 & $15 \pm 2$ & $16 \pm 2$ & $14 \pm 1$ & $14 \pm 1$ & $15 \pm 1$ & $16 \pm 1$ \\
\hline \multicolumn{7}{|c|}{ Bile acids $(\mu \mathrm{mol} / \mathrm{L})$} \\
\hline Day 4 & $23.2 \pm 1.6$ & $26.9 \pm 2.5$ & $29.8 \pm 3.4$ & $24.4 \pm 2.1$ & $24.3 \pm 1.8$ & $29.0 \pm 2.9$ \\
\hline Day 22 & $25.6 \pm 3.5$ & $29.0 \pm 2.4$ & $30.8 \pm 2.6$ & $25.7 \pm 2.4$ & $22.4 \pm 0.4$ & $28.7 \pm 1.3$ \\
\hline Week 14 & $57.2 \pm 9.7$ & $62.5 \pm 6.9$ & $69.7 \pm 6.6$ & $60.5 \pm 6.1$ & $63.2 \pm 5.6$ & $70.2 \pm 3.3$ \\
\hline \multicolumn{7}{|c|}{ 3-Hydroxybutyrate $(\mu \mathrm{mol} / \mathrm{L})$} \\
\hline Day 4 & $121.2 \pm 14.6$ & $118.6 \pm 9.6$ & $136.0 \pm 7.4$ & $102.6 \pm 8.6$ & $128.7 \pm 14.7$ & $138.3 \pm 22.9$ \\
\hline Day 22 & $109.2 \pm 14.4$ & $83.8 \pm 6.4$ & $102.0 \pm 9.7^{\mathrm{c}}$ & $100.7 \pm 13.4$ & $123.0 \pm 18.7$ & $96.9 \pm 5.9$ \\
\hline Week 14 & $323.7 \pm 52.9$ & $341.2 \pm 44.3$ & $172.9 \pm 40.3$ & $269.3 \pm 52.5$ & $221.0 \pm 40.1$ & $351.3 \pm 45.6$ \\
\hline
\end{tabular}

Free fatty acids $(\mathrm{mEq} / \mathrm{L})$

$\begin{array}{lllllll}\text { Day } 4 & 0.629 \pm 0.116 & 0.611 \pm 0.051 & 0.615 \pm 0.045 & 0.635 \pm 0.025 & 0.561 \pm 0.041 & 0.614 \pm 0.057\end{array}$

$\begin{array}{lllllll}\text { Day } 22 & 0.419 \pm 0.029 & 0.452 \pm 0.041 & 0.524 \pm 0.038 & 0.513 \pm 0.036 & 0.493 \pm 0.019 & 0.504 \pm 0.038\end{array}$

$\begin{array}{lllllll}\text { Week } 14 & 0.895 \pm 0.076 & 0.974 \pm 0.067 & 0.927 \pm 0.105 & 0.907 \pm 0.110 & 0.856 \pm 0.057 & 0.990 \pm 0.056\end{array}$

*Significantly different $(\mathrm{P} \leq 0.05)$ from the vehicle control group by Dunn's or Shirley's test.

$* * \mathrm{P} \leq 0.01$.

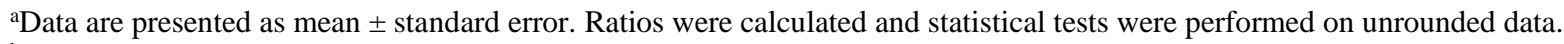

${ }^{b} \mathrm{n}=7$.

${ }^{c} n=9$.

${ }^{\mathrm{d}} \mathrm{n}=1$. 
Table C-2. Hematology Data for Mice in the Three-month Dermal Study of Sodium Thioglycolate ${ }^{a}$

\begin{tabular}{|c|c|c|c|c|c|c|}
\hline & $\begin{array}{l}\text { Vehicle } \\
\text { Control }\end{array}$ & $22.5 \mathrm{mg} / \mathrm{kg}$ & $45 \mathrm{mg} / \mathrm{kg}$ & $90 \mathrm{mg} / \mathrm{kg}$ & $180 \mathrm{mg} / \mathrm{kg}$ & $360 \mathrm{mg} / \mathrm{kg}$ \\
\hline \multicolumn{7}{|l|}{ Male } \\
\hline $\mathbf{n}$ & 10 & 10 & 9 & 10 & 10 & 10 \\
\hline Hematocrit (\%) & $50.9 \pm 0.6$ & $50.8 \pm 0.5$ & $50.9 \pm 0.5$ & $51.0 \pm 0.5$ & $51.3 \pm 0.5$ & $49.8 \pm 0.7$ \\
\hline Hemoglobin (g/dL) & $16.9 \pm 0.2$ & $16.8 \pm 0.2$ & $16.9 \pm 0.2$ & $16.9 \pm 0.2$ & $16.9 \pm 0.1$ & $16.4 \pm 0.2$ \\
\hline Erythrocytes $\left(10^{6} / \mu \mathrm{L}\right)$ & $10.88 \pm 0.11$ & $10.85 \pm 0.08$ & $10.85 \pm 0.13$ & $10.93 \pm 0.12$ & $10.90 \pm 0.09$ & $10.51 \pm 0.10^{*}$ \\
\hline Reticulocytes $\left(10^{6} / \mu \mathrm{L}\right)$ & $0.26 \pm 0.02$ & $0.27 \pm 0.01$ & $0.28 \pm 0.02$ & $0.26 \pm 0.02$ & $0.27 \pm 0.01$ & $0.26 \pm 0.01$ \\
\hline Mean cell volume (fL) & $46.2 \pm 0.3$ & $46.7 \pm 0.3$ & $46.9 \pm 0.2$ & $46.7 \pm 0.2$ & $47.1 \pm 0.2 * *$ & $47.5 \pm 0.3^{* *}$ \\
\hline $\begin{array}{l}\text { Mean cell hemoglobin } \\
\text { (pg) }\end{array}$ & $15.3 \pm 0.1$ & $15.4 \pm 0.1$ & $15.6 \pm 0.1$ & $15.4 \pm 0.1$ & $15.5 \pm 0.1^{*}$ & $15.6 \pm 0.1 * *$ \\
\hline $\begin{array}{l}\text { Mean cell hemoglobin } \\
\text { concentration }(\mathrm{g} / \mathrm{dL})\end{array}$ & $33.1 \pm 0.1$ & $33.1 \pm 0.1$ & $33.2 \pm 0.1$ & $33.1 \pm 0.1$ & $33.0 \pm 0.1$ & $33.0 \pm 0.1$ \\
\hline Platelets $\left(10^{3} / \mu \mathrm{L}\right)$ & $629.3 \pm 24.8$ & $605.3 \pm 30.7$ & $636.4 \pm 15.9$ & $579.3 \pm 24.7$ & $634.7 \pm 15.6$ & $582.8 \pm 30.1$ \\
\hline Leukocytes $\left(10^{3} / \mu \mathrm{L}\right)$ & $7.35 \pm 0.49$ & $7.22 \pm 0.69$ & $8.64 \pm 0.74$ & $7.49 \pm 0.74$ & $6.88 \pm 0.53$ & $7.51 \pm 0.62$ \\
\hline $\begin{array}{l}\text { Segmented neutrophils } \\
\qquad\left(10^{3} / \mu \mathrm{L}\right)\end{array}$ & $0.51 \pm 0.06$ & $0.47 \pm 0.08$ & $0.59 \pm 0.12$ & $0.48 \pm 0.06$ & $0.42 \pm 0.05$ & $0.53 \pm 0.09$ \\
\hline Lymphocytes $\left(10^{3} / \mu \mathrm{L}\right)$ & $6.46 \pm 0.45$ & $6.39 \pm 0.57$ & $7.68 \pm 0.62$ & $6.70 \pm 0.68$ & $6.13 \pm 0.46$ & $6.57 \pm 0.53$ \\
\hline Monocytes $\left(10^{3} / \mu \mathrm{L}\right)$ & $0.20 \pm 0.04$ & $0.15 \pm 0.02$ & $0.18 \pm 0.02$ & $0.15 \pm 0.02$ & $0.15 \pm 0.02$ & $0.17 \pm 0.02$ \\
\hline Basophils $\left(10^{3} / \mu \mathrm{L}\right)$ & $0.117 \pm 0.020$ & $0.156 \pm 0.039$ & $0.133 \pm 0.026$ & $0.111 \pm 0.021$ & $0.118 \pm 0.025$ & $0.161 \pm 0.049$ \\
\hline Eosinophils $\left(10^{3} / \mu \mathrm{L}\right)$ & $0.06 \pm 0.01$ & $0.08 \pm 0.02$ & $0.06 \pm 0.01$ & $0.05 \pm 0.01$ & $0.05 \pm 0.01$ & $0.07 \pm 0.03$ \\
\hline \multicolumn{7}{|l|}{ Female } \\
\hline $\mathbf{n}$ & 10 & 10 & 10 & 10 & 10 & 10 \\
\hline Hematocrit (\%) & $54.6 \pm 0.5$ & $51.1 \pm 0.6^{* *}$ & $51.7 \pm 0.5^{* *}$ & $53.3 \pm 0.7$ & $52.6 \pm 0.6$ & $51.1 \pm 0.6^{* *}$ \\
\hline Hemoglobin (g/dL) & $17.8 \pm 0.2$ & $16.9 \pm 0.2 * *$ & $17.0 \pm 0.1 * *$ & $17.4 \pm 0.2$ & $17.3 \pm 0.2$ & $16.8 \pm 0.2 * *$ \\
\hline Erythrocytes $\left(10^{6} / \mu \mathrm{L}\right)$ & $11.21 \pm 0.14$ & $10.59 \pm 0.14 * *$ & $10.66 \pm 0.08^{* *}$ & $10.88 \pm 0.13^{*}$ & $10.78 \pm 0.11^{*}$ & $10.37 \pm 0.11^{* *}$ \\
\hline Reticulocytes $\left(10^{6} / \mu \mathrm{L}\right)$ & $0.28 \pm 0.01$ & $0.25 \pm 0.02$ & $0.26 \pm 0.02$ & $0.28 \pm 0.02$ & $0.28 \pm 0.01$ & $0.26 \pm 0.02$ \\
\hline Mean cell volume (fL) & $48.9 \pm 0.2$ & $48.3 \pm 0.3$ & $48.4 \pm 0.2$ & $49.0 \pm 0.3$ & $49.1 \pm 0.2$ & $49.3 \pm 0.2$ \\
\hline $\begin{array}{l}\text { Mean cell hemoglobin } \\
(\mathrm{pg})\end{array}$ & $15.9 \pm 0.1$ & $16.0 \pm 0.1$ & $15.9 \pm 0.1$ & $16.0 \pm 0.1$ & $16.1 \pm 0.1 *$ & $16.2 \pm 0.1 * *$ \\
\hline $\begin{array}{l}\text { Mean cell hemoglobin } \\
\text { concentration }(\mathrm{g} / \mathrm{dL})\end{array}$ & $32.7 \pm 0.1$ & $33.1 \pm 0.1$ & $32.9 \pm 0.1$ & $32.6 \pm 0.2$ & $33.0 \pm 0.1$ & $32.9 \pm 0.1$ \\
\hline Platelets $\left(10^{3} / \mu \mathrm{L}\right)$ & $495.7 \pm 25.8$ & $495.8 \pm 32.8$ & $514.9 \pm 22.1$ & $489.1 \pm 28.8$ & $465.6 \pm 30.2$ & $511.3 \pm 36.5$ \\
\hline Leukocytes $\left(10^{3} / \mu \mathrm{L}\right)$ & $6.95 \pm 0.35$ & $6.50 \pm 0.71$ & $6.37 \pm 0.56$ & $7.84 \pm 0.65$ & $6.65 \pm 0.34$ & $5.88 \pm 0.49$ \\
\hline $\begin{array}{l}\text { Segmented neutrophils } \\
\left(10^{3} / \mu \mathrm{L}\right)\end{array}$ & $0.33 \pm 0.02$ & $0.36 \pm 0.05$ & $0.46 \pm 0.07$ & $0.55 \pm 0.09$ & $0.40 \pm 0.06$ & $0.30 \pm 0.02$ \\
\hline Lymphocytes $\left(10^{3} / \mu \mathrm{L}\right)$ & $6.37 \pm 0.32$ & $5.83 \pm 0.64$ & $5.53 \pm 0.49$ & $6.80 \pm 0.55$ & $5.96 \pm 0.31$ & $5.34 \pm 0.45$ \\
\hline Monocytes $\left(10^{3} / \mu \mathrm{L}\right)$ & $0.16 \pm 0.01$ & $0.19 \pm 0.02$ & $0.17 \pm 0.02$ & $0.21 \pm 0.02$ & $0.15 \pm 0.02$ & $0.16 \pm 0.02$ \\
\hline
\end{tabular}


Sodium Thioglycolate, NTP TOX 80

\begin{tabular}{lcccccc}
\hline & $\begin{array}{c}\text { Vehicle } \\
\text { Control }\end{array}$ & $\mathbf{2 2 . 5} \mathbf{~ m g / k g}$ & $\mathbf{4 5} \mathbf{~ m g / k g}$ & $\mathbf{9 0 ~} \mathbf{~ m g} / \mathbf{k g}$ & $\mathbf{1 8 0} \mathbf{~ m g / k g}$ & $\mathbf{3 6 0} \mathbf{~ m g} / \mathbf{k g}$ \\
\hline Basophils $\left(10^{3} / \mu \mathrm{L}\right)$ & $0.052 \pm 0.010$ & $0.092 \pm 0.021$ & $0.128 \pm 0.034$ & $0.180 \pm 0.055$ & $0.103 \pm 0.032$ & $0.055 \pm 0.008$ \\
Eosinophils $\left(10^{3} / \mu \mathrm{L}\right)$ & $0.02 \pm 0.00$ & $0.05 \pm 0.01$ & $0.06 \pm 0.02$ & $0.09 \pm 0.03$ & $0.04 \pm 0.01$ & $0.03 \pm 0.00$ \\
\hline
\end{tabular}

*Significantly different $(\mathrm{P} \leq 0.05)$ from the vehicle control group by Dunn's or Shirley's test. $* * \mathrm{P} \leq 0.01$

${ }^{\text {aD }}$ ata are presented as mean \pm standard error. Statistical tests were performed on unrounded data. 


\section{Appendix D. Organ Weights and Organ-Weight-to-Body- Weight Ratios}

\section{Tables}

Table D-1. Organ Weights and Organ-Weight-to-Body-Weight Ratios for Rats in the Two-week Dermal Study of Sodium Thioglycolate.

Table D-2. Organ Weights and Organ-Weight-to-Body-Weight Ratios for Rats in the Three-month Dermal Study of Sodium Thioglycolate....

Table D-3. Organ Weights and Organ-Weight-to-Body-Weight Ratios for Mice in the Two-week Dermal Study of Sodium Thioglycolate.

Table D-4. Organ Weights and Organ-Weight-to-Body-Weight Ratios for Mice in the Three-month Dermal Study of Sodium Thioglycolate. 
Table D-1. Organ Weights and Organ-Weight-to-Body-Weight Ratios for Rats in the Two-week Dermal Study of Sodium Thioglycolate ${ }^{\mathrm{a}}$

\begin{tabular}{|c|c|c|c|c|c|c|}
\hline & $\begin{array}{l}\text { Vehicle } \\
\text { Control }\end{array}$ & $11.25 \mathrm{mg} / \mathrm{kg}$ & $22.5 \mathrm{mg} / \mathrm{kg}$ & $45 \mathrm{mg} / \mathrm{kg}$ & $90 \mathrm{mg} / \mathrm{kg}$ & $180 \mathrm{mg} / \mathrm{kg}$ \\
\hline $\mathbf{n}$ & 5 & 5 & 5 & 5 & 5 & 5 \\
\hline \multicolumn{7}{|l|}{ Male } \\
\hline Necropsy body wt & $151 \pm 11$ & $148 \pm 4$ & $162 \pm 4$ & $152 \pm 5$ & $164 \pm 4$ & $162 \pm 6$ \\
\hline \multicolumn{7}{|l|}{ Heart } \\
\hline Absolute & $0.607 \pm 0.026$ & $0.597 \pm 0.013$ & $0.640 \pm 0.015$ & $0.615 \pm 0.023$ & $0.649 \pm 0.020$ & $0.663 \pm 0.026$ \\
\hline Relative & $4.053 \pm 0.142$ & $4.031 \pm 0.049$ & $3.948 \pm 0.103$ & $4.053 \pm 0.118$ & $3.951 \pm 0.105$ & $4.098 \pm 0.088$ \\
\hline \multicolumn{7}{|l|}{ R. Kidney } \\
\hline Absolute & $0.719 \pm 0.037$ & $0.738 \pm 0.025$ & $0.811 \pm 0.028$ & $0.754 \pm 0.037$ & $0.823 \pm 0.026^{*}$ & $0.861 \pm 0.033 * *$ \\
\hline Relative & $4.790 \pm 0.107$ & $4.977 \pm 0.072$ & $4.994 \pm 0.077$ & $4.952 \pm 0.111$ & $5.003 \pm 0.109$ & $5.325 \pm 0.118 * *$ \\
\hline \multicolumn{7}{|l|}{ Liver } \\
\hline Absolute & $7.921 \pm 0.632$ & $8.080 \pm 0.301$ & $8.715 \pm 0.299$ & $7.817 \pm 0.309$ & $9.082 \pm 0.363$ & $9.525 \pm 0.375^{*}$ \\
\hline Relative & $52.348 \pm 1.267$ & $54.567 \pm 1.960$ & $53.696 \pm 1.035$ & $51.460 \pm 1.353$ & $55.256 \pm 1.972$ & $58.881 \pm 0.842 *$ \\
\hline \multicolumn{7}{|c|}{ 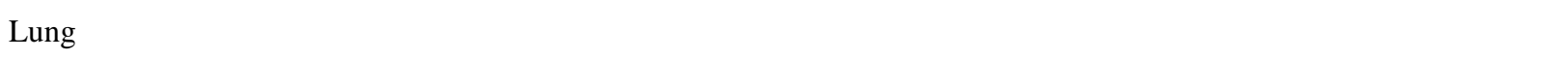 } \\
\hline Absolute & $1.801 \pm 0.067$ & $0.996 \pm 0.031 * *$ & $1.054 \pm 0.052 * *$ & $0.954 \pm 0.056^{* *}$ & $0.991 \pm 0.060 * *$ & $0.990 \pm 0.061 * *$ \\
\hline Relative & $12.220 \pm 1.155$ & $6.728 \pm 0.205^{* *}$ & $6.511 \pm 0.361 * *$ & $6.274 \pm 0.285^{* *}$ & $6.011 \pm 0.257^{* *}$ & $6.129 \pm 0.347 * *$ \\
\hline \multicolumn{7}{|l|}{ Spleen } \\
\hline Absolute & $0.443 \pm 0.030$ & $0.449 \pm 0.015$ & $0.474 \pm 0.016$ & $0.459 \pm 0.020$ & $0.497 \pm 0.019$ & $0.497 \pm 0.019$ \\
\hline Relative & $2.942 \pm 0.092$ & $3.031 \pm 0.088$ & $2.918 \pm 0.035$ & $3.015 \pm 0.043$ & $3.018 \pm 0.072$ & $3.077 \pm 0.064$ \\
\hline \multicolumn{7}{|l|}{ R. Testis } \\
\hline Absolute & $0.944 \pm 0.061$ & $0.891 \pm 0.042$ & $0.999 \pm 0.026$ & $0.933 \pm 0.026$ & $1.028 \pm 0.035$ & $0.949 \pm 0.031$ \\
\hline Relative & $6.262 \pm 0.082$ & $6.004 \pm 0.203$ & $6.162 \pm 0.090$ & $6.146 \pm 0.084$ & $6.249 \pm 0.149$ & $5.888 \pm 0.228$ \\
\hline \multicolumn{7}{|l|}{ Thymus } \\
\hline Absolute & $0.441 \pm 0.033$ & $0.424 \pm 0.018$ & $0.459 \pm 0.019$ & $0.433 \pm 0.036$ & $0.480 \pm 0.035$ & $0.475 \pm 0.022$ \\
\hline Relative & $2.916 \pm 0.068$ & $2.870 \pm 0.155$ & $2.825 \pm 0.049$ & $2.832 \pm 0.155$ & $2.921 \pm 0.201$ & $2.941 \pm 0.131$ \\
\hline \multicolumn{7}{|l|}{ Thyroid gland } \\
\hline Absolute & $0.018 \pm 0.001$ & $0.017 \pm 0.001$ & $0.017 \pm 0.001$ & $0.017 \pm 0.001$ & $0.019 \pm 0.001$ & $0.017 \pm 0.001$ \\
\hline Relative & $0.119 \pm 0.011$ & $0.112 \pm 0.002$ & $0.105 \pm 0.003$ & $0.114 \pm 0.007$ & $0.116 \pm 0.006$ & $0.105 \pm 0.003$ \\
\hline \multicolumn{7}{|l|}{ Female } \\
\hline Necropsy body wt & $128 \pm 3$ & $117 \pm 6$ & $115 \pm 3$ & $118 \pm 5$ & $120 \pm 2$ & $125 \pm 2$ \\
\hline \multicolumn{7}{|l|}{ Heart } \\
\hline Absolute & $0.531 \pm 0.016$ & $0.491 \pm 0.020$ & $0.468 \pm 0.022$ & $0.496 \pm 0.020$ & $0.485 \pm 0.012$ & $0.522 \pm 0.013$ \\
\hline Relative & $4.166 \pm 0.086$ & $4.189 \pm 0.085$ & $4.060 \pm 0.123$ & $4.204 \pm 0.024$ & $4.059 \pm 0.122$ & $4.171 \pm 0.111$ \\
\hline \multicolumn{7}{|l|}{ R. Kidney } \\
\hline Absolute & $0.664 \pm 0.032$ & $0.673 \pm 0.038$ & $0.638 \pm 0.021$ & $0.647 \pm 0.015$ & $0.704 \pm 0.028$ & $0.643 \pm 0.018$ \\
\hline Relative & $5.194 \pm 0.151$ & $5.725 \pm 0.103$ & $5.551 \pm 0.209$ & $5.501 \pm 0.163$ & $5.904 \pm 0.298$ & $5.139 \pm 0.213$ \\
\hline
\end{tabular}


Sodium Thioglycolate, NTP TOX 80

\begin{tabular}{|c|c|c|c|c|c|c|}
\hline & $\begin{array}{l}\text { Vehicle } \\
\text { Control }\end{array}$ & $11.25 \mathrm{mg} / \mathrm{kg}$ & $22.5 \mathrm{mg} / \mathrm{kg}$ & $45 \mathrm{mg} / \mathrm{kg}$ & $90 \mathrm{mg} / \mathrm{kg}$ & $180 \mathrm{mg} / \mathrm{kg}$ \\
\hline \multicolumn{7}{|l|}{ Liver } \\
\hline Absolute & $6.131 \pm 0.265$ & $5.442 \pm 0.188$ & $5.505 \pm 0.139$ & $5.789 \pm 0.356$ & $5.489 \pm 0.064$ & $5.921 \pm 0.155$ \\
\hline Relative & $47.987 \pm 1.351$ & $46.499 \pm 0.967$ & $47.843 \pm 0.665$ & $48.864 \pm 1.009$ & $45.911 \pm 0.588$ & $47.232 \pm 0.777$ \\
\hline \multicolumn{7}{|l|}{ Lung } \\
\hline Absolute & $0.914 \pm 0.064$ & $0.879 \pm 0.041$ & $0.887 \pm 0.050$ & $0.847 \pm 0.029$ & $0.841 \pm 0.030$ & $0.925 \pm 0.046$ \\
\hline Relative & $7.150 \pm 0.430$ & $7.513 \pm 0.297$ & $7.686 \pm 0.269$ & $7.187 \pm 0.082$ & $7.051 \pm 0.329$ & $7.384 \pm 0.383$ \\
\hline \multicolumn{7}{|l|}{ Spleen } \\
\hline Absolute & $0.407 \pm 0.013$ & $0.369 \pm 0.012$ & $0.346 \pm 0.021 *$ & $0.373 \pm 0.019$ & $0.386 \pm 0.009$ & $0.393 \pm 0.008$ \\
\hline Relative & $3.188 \pm 0.064$ & $3.170 \pm 0.157$ & $3.004 \pm 0.151$ & $3.154 \pm 0.048$ & $3.231 \pm 0.081$ & $3.138 \pm 0.046$ \\
\hline \multicolumn{7}{|l|}{ Thymus } \\
\hline Absolute & $0.370 \pm 0.018$ & $0.343 \pm 0.030$ & $0.308 \pm 0.038$ & $0.351 \pm 0.030$ & $0.363 \pm 0.010$ & $0.385 \pm 0.011$ \\
\hline Relative & $2.896 \pm 0.101$ & $2.915 \pm 0.190$ & $2.651 \pm 0.271$ & $2.958 \pm 0.154$ & $3.035 \pm 0.076$ & $3.075 \pm 0.102$ \\
\hline \multicolumn{7}{|c|}{ Thyroid gland } \\
\hline Absolute & $0.015 \pm 0.000$ & $0.015 \pm 0.001$ & $0.014 \pm 0.001$ & $0.014 \pm 0.000$ & $0.014 \pm 0.001$ & $0.014 \pm 0.002$ \\
\hline Relative & $0.116 \pm 0.004$ & $0.129 \pm 0.003$ & $0.118 \pm 0.003$ & $0.123 \pm 0.005$ & $0.114 \pm 0.005$ & $0.115 \pm 0.012$ \\
\hline
\end{tabular}

*Significantly different $(\mathrm{P} \leq 0.05)$ from the vehicle control group by Williams' or Dunnett's test.

$* * \mathrm{P} \leq 0.01$.

${ }^{a}$ Organ weights (absolute weights) and body weights are given in grams; organ-weight-to-body-weight ratios (relative weights) are given as mg organ weight/g body weight (mean \pm standard error). 
Table D-2. Organ Weights and Organ-Weight-to-Body-Weight Ratios for Rats in the Three-month Dermal Study of Sodium Thioglycolate ${ }^{\mathrm{a}}$

\begin{tabular}{|c|c|c|c|c|c|c|}
\hline & $\begin{array}{l}\text { Vehicle } \\
\text { Control }\end{array}$ & $11.25 \mathrm{mg} / \mathrm{kg}$ & $22.5 \mathrm{mg} / \mathrm{kg}$ & $45 \mathrm{mg} / \mathrm{kg}$ & $90 \mathrm{mg} / \mathrm{kg}$ & $180 \mathrm{mg} / \mathrm{kg}$ \\
\hline $\mathbf{n}$ & 10 & 10 & 10 & 10 & 10 & 10 \\
\hline \multicolumn{7}{|l|}{ Male } \\
\hline Necropsy body wt & $335 \pm 4$ & $334 \pm 4$ & $332 \pm 7$ & $339 \pm 5$ & $312 \pm 9^{*}$ & $319 \pm 6^{*}$ \\
\hline \multicolumn{7}{|l|}{ Heart } \\
\hline Absolute & $0.973 \pm 0.014$ & $0.981 \pm 0.022$ & $0.955 \pm 0.018$ & $0.967 \pm 0.010$ & $0.950 \pm 0.023$ & $0.932 \pm 0.019$ \\
\hline Relative & $2.908 \pm 0.031$ & $2.939 \pm 0.046$ & $2.879 \pm 0.036$ & $2.851 \pm 0.033$ & $3.050 \pm 0.050$ & $2.920 \pm 0.036$ \\
\hline \multicolumn{7}{|l|}{ R. Kidney } \\
\hline Absolute & $1.139 \pm 0.021$ & $1.197 \pm 0.026$ & $1.166 \pm 0.024$ & $1.179 \pm 0.019$ & $1.139 \pm 0.023$ & $1.173 \pm 0.024$ \\
\hline Relative & $3.404 \pm 0.044$ & $3.589 \pm 0.064$ & $3.516 \pm 0.054$ & $3.477 \pm 0.054$ & $3.658 \pm 0.042 * *$ & $3.676 \pm 0.048 * *$ \\
\hline \multicolumn{7}{|l|}{ Liver } \\
\hline Absolute & $11.22 \pm 0.27$ & $11.90 \pm 0.26$ & $11.71 \pm 0.34$ & $12.36 \pm 0.29 *$ & $10.46 \pm 0.35$ & $11.26 \pm 0.26$ \\
\hline Relative & $33.523 \pm 0.478$ & $35.665 \pm 0.616$ & $35.243 \pm 0.619$ & $36.383 \pm 0.461 * *$ & $33.531 \pm 0.738$ & $35.295 \pm 0.664$ \\
\hline \multicolumn{7}{|c|}{ 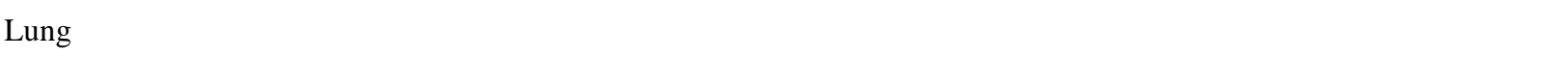 } \\
\hline Absolute & $1.532 \pm 0.063$ & $1.502 \pm 0.051$ & $1.541 \pm 0.085$ & $1.518 \pm 0.053$ & $1.451 \pm 0.045$ & $1.497 \pm 0.027$ \\
\hline Relative & $4.580 \pm 0.185$ & $4.500 \pm 0.140$ & $4.627 \pm 0.192$ & $4.477 \pm 0.156$ & $4.659 \pm 0.124$ & $4.694 \pm 0.081$ \\
\hline \multicolumn{7}{|l|}{ Spleen } \\
\hline Absolute & $0.717 \pm 0.010$ & $0.717 \pm 0.012$ & $0.719 \pm 0.017$ & $0.721 \pm 0.016$ & $0.705 \pm 0.016$ & $0.722 \pm 0.016$ \\
\hline Relative & $2.144 \pm 0.022$ & $2.149 \pm 0.029$ & $2.167 \pm 0.042$ & $2.123 \pm 0.028$ & $2.266 \pm 0.040^{*}$ & $2.262 \pm 0.031^{*}$ \\
\hline \multicolumn{7}{|l|}{ R. Testis } \\
\hline Absolute & $1.442 \pm 0.025$ & $1.468 \pm 0.023$ & $1.386 \pm 0.025$ & $1.419 \pm 0.029$ & $1.435 \pm 0.030$ & $1.482 \pm 0.028$ \\
\hline Relative & $4.315 \pm 0.089$ & $4.399 \pm 0.042$ & $4.182 \pm 0.075$ & $4.181 \pm 0.066$ & $4.614 \pm 0.082 * *$ & $4.649 \pm 0.082 * *$ \\
\hline \multicolumn{7}{|l|}{ Thymus } \\
\hline Absolute & $0.301 \pm 0.009$ & $0.315 \pm 0.016$ & $0.307 \pm 0.031$ & $0.349 \pm 0.026$ & $0.296 \pm 0.009$ & $0.317 \pm 0.013$ \\
\hline Relative & $0.899 \pm 0.022$ & $0.941 \pm 0.043$ & $0.916 \pm 0.088$ & $1.026 \pm 0.066$ & $0.959 \pm 0.050$ & $0.993 \pm 0.042$ \\
\hline \multicolumn{7}{|l|}{ Thyroid gland } \\
\hline Absolute & $0.026 \pm 0.001$ & $0.026 \pm 0.001$ & $0.027 \pm 0.001$ & $0.030 \pm 0.005$ & $0.028 \pm 0.002$ & $0.027 \pm 0.001$ \\
\hline Relative & $0.078 \pm 0.004$ & $0.077 \pm 0.003$ & $0.082 \pm 0.004$ & $0.088 \pm 0.014$ & $0.092 \pm 0.006$ & $0.084 \pm 0.004$ \\
\hline \multicolumn{7}{|l|}{ Female } \\
\hline Necropsy body wt & $177 \pm 3$ & $185 \pm 3$ & $185 \pm 3$ & $186 \pm 3$ & $180 \pm 4$ & $173 \pm 4$ \\
\hline \multicolumn{7}{|l|}{ Heart } \\
\hline Absolute & $0.652 \pm 0.013$ & $0.646 \pm 0.016$ & $0.658 \pm 0.008$ & $0.647 \pm 0.011$ & $0.666 \pm 0.016$ & $0.643 \pm 0.017$ \\
\hline Relative & $3.679 \pm 0.040$ & $3.478 \pm 0.047$ & $3.575 \pm 0.066$ & $3.482 \pm 0.045$ & $3.709 \pm 0.081$ & $3.711 \pm 0.060$ \\
\hline \multicolumn{7}{|l|}{ R. Kidney } \\
\hline Absolute & $0.695 \pm 0.014$ & $0.726 \pm 0.009$ & $0.716 \pm 0.010$ & $0.723 \pm 0.020$ & $0.746 \pm 0.021$ & $0.724 \pm 0.017$ \\
\hline Relative & $3.922 \pm 0.041$ & $3.914 \pm 0.025$ & $3.884 \pm 0.045$ & $3.889 \pm 0.087$ & $4.147 \pm 0.090 *$ & $4.181 \pm 0.069 * *$ \\
\hline
\end{tabular}


Sodium Thioglycolate, NTP TOX 80

\begin{tabular}{|c|c|c|c|c|c|c|}
\hline & $\begin{array}{l}\text { Vehicle } \\
\text { Control }\end{array}$ & $11.25 \mathrm{mg} / \mathrm{kg}$ & $22.5 \mathrm{mg} / \mathrm{kg}$ & $45 \mathrm{mg} / \mathrm{kg}$ & $90 \mathrm{mg} / \mathrm{kg}$ & $180 \mathrm{mg} / \mathrm{kg}$ \\
\hline \multicolumn{7}{|l|}{ Liver } \\
\hline Absolute & $5.602 \pm 0.173$ & $5.587 \pm 0.123$ & $6.036 \pm 0.156$ & $5.896 \pm 0.153$ & $5.945 \pm 0.141$ & $5.659 \pm 0.127$ \\
\hline Relative & $31.564 \pm 0.680$ & $30.129 \pm 0.484$ & $32.693 \pm 0.571$ & $31.674 \pm 0.481$ & $33.084 \pm 0.659$ & $32.707 \pm 0.689$ \\
\hline \multicolumn{7}{|l|}{ Lung } \\
\hline Absolute & $1.053 \pm 0.029$ & $1.001 \pm 0.043$ & $0.978 \pm 0.022$ & $1.101 \pm 0.047$ & $1.059 \pm 0.041$ & $1.070 \pm 0.090$ \\
\hline Relative & $5.930 \pm 0.083$ & $5.394 \pm 0.197$ & $5.302 \pm 0.104$ & $5.932 \pm 0.266$ & $5.882 \pm 0.179$ & $6.167 \pm 0.491$ \\
\hline \multicolumn{7}{|l|}{ Spleen } \\
\hline Absolute & $0.441 \pm 0.007$ & $0.448 \pm 0.009$ & $0.444 \pm 0.006$ & $0.451 \pm 0.012$ & $0.442 \pm 0.012$ & $0.432 \pm 0.013$ \\
\hline Relative & $2.488 \pm 0.023$ & $2.416 \pm 0.044$ & $2.409 \pm 0.035$ & $2.423 \pm 0.048$ & $2.460 \pm 0.066$ & $2.488 \pm 0.040$ \\
\hline \multicolumn{7}{|l|}{ Thymus } \\
\hline Absolute & $0.259 \pm 0.032$ & $0.254 \pm 0.006$ & $0.231 \pm 0.007$ & $0.233 \pm 0.007$ & $0.230 \pm 0.007$ & $0.230 \pm 0.011$ \\
\hline Relative & $1.474 \pm 0.208$ & $1.370 \pm 0.028$ & $1.252 \pm 0.041$ & $1.253 \pm 0.040$ & $1.282 \pm 0.045$ & $1.333 \pm 0.067$ \\
\hline \multicolumn{7}{|c|}{ Thyroid gland } \\
\hline Absolute & $0.026 \pm 0.001$ & $0.026 \pm 0.001$ & $0.023 \pm 0.001$ & $0.024 \pm 0.001$ & $0.026 \pm 0.001^{b}$ & $0.023 \pm 0.001^{\mathrm{b}}$ \\
\hline Relative & $0.145 \pm 0.005$ & $0.141 \pm 0.006$ & $0.123 \pm 0.004 *$ & $0.130 \pm 0.007$ & $0.140 \pm 0.006^{\mathrm{b}}$ & $0.133 \pm 0.003^{b}$ \\
\hline
\end{tabular}

*Significantly different $(\mathrm{P} \leq 0.05)$ from the vehicle control group by Williams' or Dunnett's test.

$* * \mathrm{P} \leq 0.01$.

${ }^{a}$ Organ weights (absolute weights) and body weights are given in grams; organ-weight-to-body-weight ratios (relative weights) are given as $\mathrm{mg}$ organ weight/g body weight (mean \pm standard error).

${ }^{b} \mathrm{n}=9$. 
Table D-3. Organ Weights and Organ-Weight-to-Body-Weight Ratios for Mice in the Two-week Dermal Study of Sodium Thioglycolate ${ }^{\mathrm{a}}$

\begin{tabular}{|c|c|c|c|c|c|c|}
\hline & $\begin{array}{l}\text { Vehicle } \\
\text { Control }\end{array}$ & $22.5 \mathrm{mg} / \mathrm{kg}$ & $45 \mathrm{mg} / \mathrm{kg}$ & $90 \mathrm{mg} / \mathrm{kg}$ & $180 \mathrm{mg} / \mathrm{kg}$ & $360 \mathrm{mg} / \mathrm{kg}$ \\
\hline \multicolumn{7}{|l|}{ Male } \\
\hline n & 5 & 5 & 5 & 5 & 5 & 5 \\
\hline Necropsy body wt & $23.6 \pm 0.5$ & $23.5 \pm 0.3$ & $24.7 \pm 0.9$ & $23.9 \pm 0.3$ & $25.1 \pm 0.4$ & $24.7 \pm 0.4$ \\
\hline \multicolumn{7}{|l|}{ Heart } \\
\hline Absolute & $0.144 \pm 0.004$ & $0.137 \pm 0.006$ & $0.140 \pm 0.007$ & $0.137 \pm 0.003$ & $0.146 \pm 0.002$ & $0.145 \pm 0.006$ \\
\hline Relative & $6.080 \pm 0.082$ & $5.809 \pm 0.197$ & $5.634 \pm 0.106$ & $5.749 \pm 0.100$ & $5.825 \pm 0.166$ & $5.874 \pm 0.178$ \\
\hline \multicolumn{7}{|l|}{ R. Kidney } \\
\hline Absolute & $0.313 \pm 0.014$ & $0.262 \pm 0.012$ & $0.297 \pm 0.022$ & $0.279 \pm 0.006$ & $0.309 \pm 0.015$ & $0.326 \pm 0.025$ \\
\hline Relative & $13.232 \pm 0.457$ & $11.136 \pm 0.460$ & $11.932 \pm 0.496$ & $11.704 \pm 0.247$ & $12.299 \pm 0.556$ & $13.178 \pm 0.910$ \\
\hline \multicolumn{7}{|l|}{ Liver } \\
\hline Absolute & $1.486 \pm 0.067$ & $1.456 \pm 0.029$ & $1.525 \pm 0.059$ & $1.446 \pm 0.034$ & $1.570 \pm 0.032$ & $1.533 \pm 0.062$ \\
\hline Relative & $62.757 \pm 1.864$ & $61.957 \pm 0.667$ & $61.686 \pm 1.239$ & $60.588 \pm 1.068$ & $62.475 \pm 0.989$ & $61.981 \pm 1.697$ \\
\hline \multicolumn{7}{|l|}{ Lung } \\
\hline Absolute & $0.210 \pm 0.018$ & $0.215 \pm 0.014$ & $0.210 \pm 0.014$ & $0.198 \pm 0.013$ & $0.214 \pm 0.004$ & $0.187 \pm 0.016$ \\
\hline Relative & $8.875 \pm 0.733$ & $9.149 \pm 0.579$ & $8.447 \pm 0.284$ & $8.296 \pm 0.515$ & $8.532 \pm 0.310$ & $7.574 \pm 0.626$ \\
\hline \multicolumn{7}{|l|}{ Spleen } \\
\hline Absolute & $0.077 \pm 0.004$ & $0.071 \pm 0.003$ & $0.082 \pm 0.007$ & $0.075 \pm 0.002$ & $0.079 \pm 0.003$ & $0.077 \pm 0.004$ \\
\hline Relative & $3.244 \pm 0.113$ & $3.005 \pm 0.112$ & $3.294 \pm 0.203$ & $3.141 \pm 0.123$ & $3.147 \pm 0.075$ & $3.103 \pm 0.133$ \\
\hline \multicolumn{7}{|l|}{ R. Testis } \\
\hline Absolute & $0.108 \pm 0.003$ & $0.105 \pm 0.003$ & $0.108 \pm 0.006$ & $0.102 \pm 0.003$ & $0.108 \pm 0.001$ & $0.105 \pm 0.005$ \\
\hline Relative & $4.554 \pm 0.136$ & $4.454 \pm 0.142$ & $4.354 \pm 0.132$ & $4.286 \pm 0.139$ & $4.309 \pm 0.082$ & $4.250 \pm 0.158$ \\
\hline \multicolumn{7}{|l|}{ Thymus } \\
\hline Absolute & $0.055 \pm 0.007$ & $0.050 \pm 0.005$ & $0.055 \pm 0.003$ & $0.053 \pm 0.005$ & $0.053 \pm 0.003$ & $0.053 \pm 0.005$ \\
\hline Relative & $2.293 \pm 0.257$ & $2.109 \pm 0.202$ & $2.228 \pm 0.106$ & $2.242 \pm 0.237$ & $2.114 \pm 0.108$ & $2.138 \pm 0.164$ \\
\hline \multicolumn{7}{|l|}{ Thyroid gland } \\
\hline Absolute & $0.004 \pm 0.001$ & $0.005 \pm 0.001$ & $0.004 \pm 0.000$ & $0.004 \pm 0.000$ & $0.003 \pm 0.000$ & $0.004 \pm 0.001$ \\
\hline Relative & $0.152 \pm 0.031$ & $0.203 \pm 0.033$ & $0.163 \pm 0.016$ & $0.176 \pm 0.008$ & $0.119 \pm 0.012$ & $0.147 \pm 0.022$ \\
\hline
\end{tabular}

Female

\begin{tabular}{lcccccc}
$\mathbf{n}$ & 5 & 5 & 5 & 5 & 5 & 4 \\
\hline Necropsy body wt & $21.3 \pm 0.2$ & $21.2 \pm 0.3$ & $21.5 \pm 0.2$ & $21.8 \pm 0.3$ & $22.1 \pm 0.5$ & $22.2 \pm 0.6$
\end{tabular}

Heart

\begin{tabular}{lllllll} 
Absolute & $0.132 \pm 0.003$ & $0.134 \pm 0.005$ & $0.135 \pm 0.004$ & $0.132 \pm 0.005$ & $0.133 \pm 0.004$ & $0.128 \pm 0.008$ \\
Relative & $6.201 \pm 0.153$ & $6.350 \pm 0.201$ & $6.273 \pm 0.161$ & $6.062 \pm 0.218$ & $5.998 \pm 0.097$ & $5.755 \pm 0.255$ \\
\hline
\end{tabular}


Sodium Thioglycolate, NTP TOX 80

\begin{tabular}{|c|c|c|c|c|c|c|}
\hline & $\begin{array}{l}\text { Vehicle } \\
\text { Control } \\
\end{array}$ & $22.5 \mathrm{mg} / \mathrm{kg}$ & $45 \mathrm{mg} / \mathrm{kg}$ & $90 \mathrm{mg} / \mathrm{kg}$ & $180 \mathrm{mg} / \mathrm{kg}$ & $360 \mathrm{mg} / \mathrm{kg}$ \\
\hline \multicolumn{7}{|l|}{ R. Kidney } \\
\hline Absolute & $0.224 \pm 0.012$ & $0.228 \pm 0.020$ & $0.220 \pm 0.010$ & $0.223 \pm 0.011$ & $0.233 \pm 0.014$ & $0.231 \pm 0.027$ \\
\hline Relative & $10.535 \pm 0.577$ & $10.766 \pm 0.935$ & $10.231 \pm 0.506$ & $10.256 \pm 0.497$ & $10.519 \pm 0.622$ & $10.362 \pm 1.090$ \\
\hline \multicolumn{7}{|l|}{ Liver } \\
\hline Absolute & $1.395 \pm 0.045$ & $1.393 \pm 0.051$ & $1.347 \pm 0.038$ & $1.337 \pm 0.059$ & $1.442 \pm 0.052$ & $1.401 \pm 0.072$ \\
\hline Relative & $65.552 \pm 1.577$ & $65.803 \pm 1.838$ & $62.537 \pm 1.772$ & $61.277 \pm 1.895$ & $65.060 \pm 1.094$ & $62.973 \pm 1.718$ \\
\hline \multicolumn{7}{|l|}{ Lung } \\
\hline Absolute & $0.199 \pm 0.012$ & $0.206 \pm 0.013$ & $0.202 \pm 0.006$ & $0.187 \pm 0.009$ & $0.196 \pm 0.014$ & $0.196 \pm 0.013$ \\
\hline Relative & $9.368 \pm 0.612$ & $9.743 \pm 0.593$ & $9.402 \pm 0.330$ & $8.625 \pm 0.478$ & $8.843 \pm 0.513$ & $8.798 \pm 0.461$ \\
\hline \multicolumn{7}{|l|}{ Spleen } \\
\hline Absolute & $0.103 \pm 0.008$ & $0.097 \pm 0.003$ & $0.102 \pm 0.004$ & $0.097 \pm 0.004$ & $0.099 \pm 0.005$ & $0.092 \pm 0.006$ \\
\hline Relative & $4.827 \pm 0.380$ & $4.571 \pm 0.158$ & $4.749 \pm 0.190$ & $4.447 \pm 0.117$ & $4.475 \pm 0.186$ & $4.132 \pm 0.256$ \\
\hline \multicolumn{7}{|l|}{ Thymus } \\
\hline Absolute & $0.076 \pm 0.003$ & $0.091 \pm 0.004$ & $0.079 \pm 0.006$ & $0.072 \pm 0.003$ & $0.079 \pm 0.005$ & $0.083 \pm 0.008$ \\
\hline Relative & $3.552 \pm 0.129$ & $4.296 \pm 0.196$ & $3.679 \pm 0.279$ & $3.296 \pm 0.138$ & $3.556 \pm 0.256$ & $3.726 \pm 0.303$ \\
\hline \multicolumn{7}{|c|}{ Thyroid gland } \\
\hline Absolute & $0.003 \pm 0.000$ & $0.004 \pm 0.000$ & $0.005 \pm 0.000 *$ & $0.003 \pm 0.000$ & $0.005 \pm 0.000$ & $0.003 \pm 0.000$ \\
\hline Relative & $0.151 \pm 0.018$ & $0.179 \pm 0.022$ & $0.222 \pm 0.016^{*}$ & $0.157 \pm 0.013$ & $0.208 \pm 0.019$ & $0.147 \pm 0.023$ \\
\hline
\end{tabular}

*Significantly different $(\mathrm{P} \leq 0.05)$ from the vehicle control group by Dunnett's test.

a Organ weights (absolute weights) and body weights are given in grams; organ-weight-to-body-weight ratios (relative weights) are given as $\mathrm{mg}$ organ weight/g body weight (mean \pm standard error). 
Table D-4. Organ Weights and Organ-Weight-to-Body-Weight Ratios for Mice in the Three-month Dermal Study of Sodium Thioglycolate ${ }^{\mathrm{a}}$

\begin{tabular}{|c|c|c|c|c|c|c|}
\hline & $\begin{array}{l}\text { Vehicle } \\
\text { Control }\end{array}$ & $22.5 \mathrm{mg} / \mathrm{kg}$ & $45 \mathrm{mg} / \mathrm{kg}$ & $90 \mathrm{mg} / \mathrm{kg}$ & $180 \mathrm{mg} / \mathrm{kg}$ & $360 \mathrm{mg} / \mathrm{kg}$ \\
\hline $\mathbf{n}$ & 10 & 10 & 10 & 10 & 10 & 10 \\
\hline \multicolumn{7}{|l|}{ Male } \\
\hline Necropsy body wt & $29.0 \pm 0.5$ & $28.2 \pm 0.3$ & $28.1 \pm 0.7$ & $28.2 \pm 0.6$ & $28.8 \pm 0.4$ & $28.3 \pm 0.3$ \\
\hline \multicolumn{7}{|l|}{ Heart } \\
\hline Absolute & $0.137 \pm 0.002$ & $0.147 \pm 0.002$ & $0.147 \pm 0.004$ & $0.141 \pm 0.002$ & $0.148 \pm 0.002 *$ & $0.148 \pm 0.002 *$ \\
\hline Relative & $4.725 \pm 0.041$ & $5.196 \pm 0.087 * *$ & $5.213 \pm 0.087 * *$ & $5.018 \pm 0.110 * *$ & $5.141 \pm 0.067 * *$ & $5.247 \pm 0.080 * *$ \\
\hline \multicolumn{7}{|l|}{ R. Kidney } \\
\hline Absolute & $0.282 \pm 0.009$ & $0.280 \pm 0.007$ & $0.266 \pm 0.007$ & $0.283 \pm 0.009$ & $0.287 \pm 0.007$ & $0.296 \pm 0.008$ \\
\hline Relative & $9.714 \pm 0.178$ & $9.918 \pm 0.173$ & $9.450 \pm 0.120$ & $10.041 \pm 0.227$ & $9.942 \pm 0.143$ & $10.449 \pm 0.216^{*}$ \\
\hline \multicolumn{7}{|l|}{ Liver } \\
\hline Absolute & $1.300 \pm 0.022$ & $1.281 \pm 0.028$ & $1.251 \pm 0.023$ & $1.329 \pm 0.035$ & $1.404 \pm 0.025^{* *}$ & $1.409 \pm 0.025^{* *}$ \\
\hline Relative & $44.876 \pm 0.512$ & $45.361 \pm 0.801$ & $44.580 \pm 0.621$ & $47.151 \pm 0.851^{*}$ & $48.771 \pm 0.692 * *$ & $49.844 \pm 0.696 * *$ \\
\hline \multicolumn{7}{|l|}{ Lung } \\
\hline Absolute & $0.205 \pm 0.007$ & $0.212 \pm 0.011$ & $0.202 \pm 0.006$ & $0.220 \pm 0.012$ & $0.214 \pm 0.011$ & $0.224 \pm 0.017$ \\
\hline Relative & $7.103 \pm 0.296$ & $7.494 \pm 0.342$ & $7.210 \pm 0.287$ & $7.824 \pm 0.415$ & $7.397 \pm 0.306$ & $7.917 \pm 0.588$ \\
\hline \multicolumn{7}{|l|}{ Spleen } \\
\hline Absolute & $0.059 \pm 0.002$ & $0.052 \pm 0.001$ & $0.054 \pm 0.001$ & $0.059 \pm 0.002$ & $0.061 \pm 0.001$ & $0.063 \pm 0.002$ \\
\hline Relative & $2.046 \pm 0.056$ & $1.824 \pm 0.043$ & $1.940 \pm 0.064$ & $2.108 \pm 0.060$ & $2.118 \pm 0.026$ & $2.230 \pm 0.070^{*}$ \\
\hline \multicolumn{7}{|l|}{ R. Testis } \\
\hline Absolute & $0.118 \pm 0.002$ & $0.120 \pm 0.002$ & $0.124 \pm 0.002$ & $0.117 \pm 0.001$ & $0.119 \pm 0.002$ & $0.115 \pm 0.003$ \\
\hline Relative & $4.079 \pm 0.073$ & $4.240 \pm 0.085$ & $4.423 \pm 0.147$ & $4.146 \pm 0.074$ & $4.145 \pm 0.086$ & $4.066 \pm 0.091$ \\
\hline \multicolumn{7}{|l|}{ Thymus } \\
\hline Absolute & $0.040 \pm 0.005$ & $0.035 \pm 0.002$ & $0.041 \pm 0.003$ & $0.038 \pm 0.003$ & $0.047 \pm 0.005$ & $0.040 \pm 0.003$ \\
\hline Relative & $1.402 \pm 0.165$ & $1.244 \pm 0.076$ & $1.455 \pm 0.129$ & $1.362 \pm 0.098$ & $1.654 \pm 0.182$ & $1.400 \pm 0.117$ \\
\hline \multicolumn{7}{|l|}{ Thyroid gland } \\
\hline Absolute & $0.005 \pm 0.001$ & $0.005 \pm 0.000$ & $0.005 \pm 0.001$ & $0.006 \pm 0.000$ & $0.005 \pm 0.000$ & $0.006 \pm 0.001$ \\
\hline Relative & $0.175 \pm 0.021$ & $0.166 \pm 0.015$ & $0.182 \pm 0.022$ & $0.197 \pm 0.015$ & $0.187 \pm 0.009$ & $0.196 \pm 0.019$ \\
\hline \multicolumn{7}{|l|}{ Female } \\
\hline Necropsy body wt & $24.4 \pm 0.5$ & $24.8 \pm 0.4$ & $25.4 \pm 0.7$ & $24.6 \pm 0.5$ & $25.3 \pm 0.4$ & $25.5 \pm 0.4$ \\
\hline \multicolumn{7}{|l|}{ Heart } \\
\hline Absolute & $0.124 \pm 0.003$ & $0.131 \pm 0.003$ & $0.134 \pm 0.002 *$ & $0.129 \pm 0.002 *$ & $0.134 \pm 0.003 * *$ & $0.140 \pm 0.003^{* *}$ \\
\hline Relative & $5.074 \pm 0.097$ & $5.278 \pm 0.094$ & $5.300 \pm 0.117$ & $5.257 \pm 0.104$ & $5.307 \pm 0.135$ & $5.481 \pm 0.109 *$ \\
\hline \multicolumn{7}{|l|}{ R. Kidney } \\
\hline Absolute & $0.179 \pm 0.006$ & $0.189 \pm 0.005$ & $0.191 \pm 0.004$ & $0.184 \pm 0.004$ & $0.196 \pm 0.003 *$ & $0.198 \pm 0.002 *$ \\
\hline Relative & $7.350 \pm 0.166$ & $7.610 \pm 0.180$ & $7.531 \pm 0.201$ & $7.482 \pm 0.133$ & $7.743 \pm 0.089$ & $7.755 \pm 0.111$ \\
\hline
\end{tabular}


Sodium Thioglycolate, NTP TOX 80

\begin{tabular}{|c|c|c|c|c|c|c|}
\hline & $\begin{array}{l}\text { Vehicle } \\
\text { Control }\end{array}$ & $22.5 \mathrm{mg} / \mathrm{kg}$ & $45 \mathrm{mg} / \mathrm{kg}$ & $90 \mathrm{mg} / \mathrm{kg}$ & $180 \mathrm{mg} / \mathrm{kg}$ & $360 \mathrm{mg} / \mathrm{kg}$ \\
\hline \multicolumn{7}{|l|}{ Liver } \\
\hline Absolute & $1.118 \pm 0.030$ & $1.197 \pm 0.029 *$ & $1.256 \pm 0.025 * *$ & $1.233 \pm 0.033 * *$ & $1.285 \pm 0.019 * *$ & $1.337 \pm 0.027 * *$ \\
\hline Relative & $45.867 \pm 0.844$ & $48.279 \pm 0.873$ & $49.544 \pm 1.129 * *$ & $50.063 \pm 0.924 * *$ & $50.930 \pm 0.677 * *$ & $52.404 \pm 0.821 * *$ \\
\hline \multicolumn{7}{|l|}{ Lung } \\
\hline Absolute & $0.225 \pm 0.015$ & $0.225 \pm 0.017$ & $0.193 \pm 0.009$ & $0.230 \pm 0.013$ & $0.238 \pm 0.017$ & $0.211 \pm 0.008$ \\
\hline Relative & $9.200 \pm 0.497$ & $9.100 \pm 0.715$ & $7.627 \pm 0.424$ & $9.332 \pm 0.518$ & $9.469 \pm 0.725$ & $8.260 \pm 0.323$ \\
\hline \multicolumn{7}{|l|}{ Spleen } \\
\hline Absolute & $0.073 \pm 0.003$ & $0.082 \pm 0.003$ & $0.084 \pm 0.003^{*}$ & $0.080 \pm 0.002$ & $0.081 \pm 0.003$ & $0.085 \pm 0.004 *$ \\
\hline Relative & $2.986 \pm 0.091$ & $3.317 \pm 0.139$ & $3.305 \pm 0.080$ & $3.243 \pm 0.091$ & $3.214 \pm 0.135$ & $3.315 \pm 0.142$ \\
\hline \multicolumn{7}{|l|}{ Thymus } \\
\hline Absolute & $0.050 \pm 0.002$ & $0.049 \pm 0.002$ & $0.049 \pm 0.003$ & $0.046 \pm 0.003$ & $0.047 \pm 0.002$ & $0.047 \pm 0.003$ \\
\hline Relative & $2.035 \pm 0.077$ & $2.002 \pm 0.091$ & $1.926 \pm 0.121$ & $1.869 \pm 0.094$ & $1.871 \pm 0.061$ & $1.840 \pm 0.096$ \\
\hline \multicolumn{7}{|c|}{ Thyroid gland } \\
\hline Absolute & $0.006 \pm 0.000$ & $0.005 \pm 0.000$ & $0.005 \pm 0.000$ & $0.006 \pm 0.000$ & $0.006 \pm 0.000$ & $0.006 \pm 0.000$ \\
\hline Relative & $0.239 \pm 0.011$ & $0.214 \pm 0.013$ & $0.200 \pm 0.018$ & $0.233 \pm 0.018$ & $0.230 \pm 0.010$ & $0.247 \pm 0.012$ \\
\hline
\end{tabular}

*Significantly different $(\mathrm{P} \leq 0.05)$ from the vehicle control group by Williams' or Dunnett's test.

$* * \mathrm{P} \leq 0.01$.

${ }^{\mathrm{a}}$ Organ weights (absolute weights) and body weights are given in grams; organ-weight-to-body-weight ratios (relative weights) are given as mg organ weight/g body weight (mean \pm standard error). 


\section{Appendix E. Reproductive Tissue Evaluations and Estrous Cycle Characterization}

\section{Tables}

Table E-1. Summary of Reproductive Tissue Evaluations for Male Rats in the

Three-month Dermal Study of Sodium Thioglycolate

Table E-2. Estrous Cycle Characterization for Female Rats in the Three-month Dermal Study of Sodium Thioglycolate.

Table E-3. Summary of Reproductive Tissue Evaluations for Male Mice in the Three-month Dermal Study of Sodium Thioglycolate

Table E-4. Estrous Cycle Characterization for Female Mice in the Three-month Dermal

Study of Sodium Thioglycolate 
Table E-1. Summary of Reproductive Tissue Evaluations for Male Rats in the Three-month Dermal Study of Sodium Thioglycolate ${ }^{\mathrm{a}}$

\begin{tabular}{|c|c|c|c|c|}
\hline & Vehicle Control & $45 \mathrm{mg} / \mathrm{kg}$ & $90 \mathrm{mg} / \mathrm{kg}$ & $180 \mathrm{mg} / \mathrm{kg}$ \\
\hline n & 10 & 10 & 10 & 10 \\
\hline \multicolumn{5}{|l|}{ Weights (g) } \\
\hline Necropsy body wt & $335 \pm 4$ & $339 \pm 5$ & $312 \pm 9^{*}$ & $319 \pm 6^{*}$ \\
\hline L. Cauda epididymis & $0.1736 \pm 0.0077$ & $0.1761 \pm 0.0048$ & $0.1681 \pm 0.0040$ & $0.1746 \pm 0.0038$ \\
\hline L. Epididymis & $0.4638 \pm 0.0094$ & $0.4829 \pm 0.0098$ & $0.4601 \pm 0.0093$ & $0.4698 \pm 0.0101$ \\
\hline L. Testis & $1.5131 \pm 0.0132$ & $1.5008 \pm 0.0252$ & $1.4782 \pm 0.0295$ & $1.5296 \pm 0.0283$ \\
\hline
\end{tabular}

Spermatid measurements

Spermatid heads $\left(10^{6} /\right.$ testis $)$

Spermatid heads $\left(10^{6} / \mathrm{g}\right.$ testis $)$

Epididymal spermatozoal measurements

Sperm motility (\%)

Sperm (10\% $/$ cauda epididymis)

Sperm $\left(10^{6} / \mathrm{g}\right.$ cauda epididymis $)$

$$
\begin{array}{llll}
174.4 \pm 6.3 & 177.0 \pm 6.7 & 164.8 \pm 5.3 & 179.6 \pm 7.8 \\
125.4 \pm 4.4 & 127.8 \pm 4.1 & 122.2 \pm 3.5 & 128.8 \pm 4.2
\end{array}
$$

$\begin{array}{cccc}81.80 \pm 1.06 & 82.90 \pm 0.86 & 82.22 \pm 0.76^{\mathrm{b}} & 83.50 \pm 0.60 \\ 53.55 \pm 9.53 & 58.00 \pm 6.03 & 50.50 \pm 9.69 & 50.55 \pm 7.25 \\ 323 \pm 68 & 328 \pm 33 & 298 \pm 54 & 288 \pm 38\end{array}$

*Significantly different $(\mathrm{P} \leq 0.05)$ from the vehicle control group by Williams' test.

aData are presented as mean \pm standard error. Differences from the vehicle control group are not significant by Dunnett's test (tissue weights) or Dunn's test (spermatid and epididymal spermatozoal measurements).

${ }^{b} \mathrm{n}=9$.

Table E-2. Estrous Cycle Characterization for Female Rats in the Three-month Dermal Study of Sodium Thioglycolate ${ }^{\mathrm{a}}$

\begin{tabular}{lcccc}
\hline & Vehicle Control & $\mathbf{4 5} \mathbf{~} \mathbf{~ g} / \mathbf{k g}$ & $\mathbf{9 0} \mathbf{~} \mathbf{g} / \mathbf{k g}$ & $\mathbf{1 8 0} \mathbf{~} \mathbf{g} / \mathbf{k g}$ \\
\hline Number weighed at necropsy & 10 & 10 & 10 & 10 \\
Necropsy body wt (g) & $177 \pm 3$ & $186 \pm 3$ & $180 \pm 4$ & $173 \pm 4$ \\
Estrous cycle length (days) & $5.00 \pm 0.00$ & $4.75 \pm 0.23$ & $5.10 \pm 0.10$ & $4.90 \pm 0.19$ \\
Estrous stages (\% of cycle) & & & & \\
Diestrus & 58.3 & 63.3 & 53.3 & 63.3 \\
Proestrus & 20.0 & 15.0 & 18.3 & 15.0 \\
Estrus & 20.8 & 20.8 & 23.3 & 20.0 \\
Metestrus & 0.8 & 0.8 & 5.0 & 1.7 \\
\hline
\end{tabular}

${ }^{a}$ Necropsy body weights and estrous cycle length data are presented as mean \pm standard error. Differences from the vehicle control group are not significant by Dunnett's test (body weight) or Dunn's test (estrous cycle length). By multivariate analysis of variance, dosed females do not differ significantly from the vehicle control females in the relative length of time spent in the estrous stages. 
Table E-3. Summary of Reproductive Tissue Evaluations for Male Mice in the Three-month Dermal Study of Sodium Thioglycolate ${ }^{a}$

\begin{tabular}{|c|c|c|c|c|}
\hline & Vehicle Control & $90 \mathrm{mg} / \mathrm{kg}$ & $180 \mathrm{mg} / \mathrm{kg}$ & $360 \mathrm{mg} / \mathrm{kg}$ \\
\hline $\mathbf{n}$ & 10 & 10 & 10 & 10 \\
\hline \multicolumn{5}{|l|}{ Weights (g) } \\
\hline Necropsy body wt & $29.0 \pm 0.5$ & $28.2 \pm 0.6$ & $28.8 \pm 0.4$ & $28.3 \pm 0.3$ \\
\hline L. Cauda epididymis & $0.0154 \pm 0.0007$ & $0.0158 \pm 0.0005$ & $0.0143 \pm 0.0007$ & $0.0167 \pm 0.0008$ \\
\hline L. Epididymis & $0.0472 \pm 0.0021$ & $0.0467 \pm 0.0014$ & $0.0479 \pm 0.0021$ & $0.0483 \pm 0.0015$ \\
\hline L. Testis & $0.1101 \pm 0.0011$ & $0.1120 \pm 0.0017$ & $0.1092 \pm 0.0026$ & $0.1079 \pm 0.0030$ \\
\hline \multicolumn{5}{|l|}{ Spermatid measurements } \\
\hline Spermatid heads $\left(10^{6} /\right.$ testis $)$ & $18.42 \pm 0.74$ & $19.43 \pm 0.56$ & $18.75 \pm 1.01$ & $18.03 \pm 1.24$ \\
\hline Spermatid heads $\left(10^{6} / \mathrm{g}\right.$ testis $)$ & $175.2 \pm 6.4$ & $187.3 \pm 4.3$ & $184.9 \pm 7.7$ & $182.0 \pm 9.0$ \\
\hline \multicolumn{5}{|c|}{ Epididymal spermatozoal measurements } \\
\hline Sperm motility (\%) & $83.89 \pm 0.61^{\mathrm{b}}$ & $84.50 \pm 1.27$ & $84.10 \pm 0.87$ & $84.00 \pm 0.58$ \\
\hline Sperm ( $10^{6} /$ cauda epididymis) & $12.244 \pm 1.630^{\mathrm{b}}$ & $12.790 \pm 1.519$ & $9.340 \pm 1.036$ & $9.780 \pm 0.797$ \\
\hline Sperm $\left(10^{6} / \mathrm{g}\right.$ cauda epididymi & $809 \pm 115^{\mathrm{b}}$ & $826 \pm 115$ & $680 \pm 101$ & $596 \pm 52$ \\
\hline \multicolumn{5}{|c|}{$\begin{array}{l}\text { 'Data are presented as mean } \pm \text { standard error. Differences from the vehicle control group are not significant by Dunnett's test } \\
\text { (body and tissue weights) or Dunn's test (spermatid and epididymal spermatozoal measurements). } \\
{ }^{\circ} \mathrm{n}=9 \text {. }\end{array}$} \\
\hline \multicolumn{5}{|c|}{$\begin{array}{l}\text { Table E-4. Estrous Cycle Characterization for Female Mice in the Three-month Dermal Study of } \\
\text { Sodium Thioglycolate }\end{array}$} \\
\hline \multicolumn{2}{|r|}{ Vehicle Control } & 90 mg/kg & 180 mg/kg & $360 \mathrm{mg} / \mathrm{kg}$ \\
\hline Number weighed at necropsy & 10 & 10 & 10 & 10 \\
\hline Necropsy body wt (g) & $24.4 \pm 0.5$ & $24.6 \pm 0.5$ & $25.3 \pm 0.4$ & $25.5 \pm 0.4$ \\
\hline Estrous cycle length (days) & $4.05 \pm 0.05$ & $.95 \pm 0.05$ & $4.20 \pm 0.11$ & $4.10 \pm 0.07$ \\
\hline \multicolumn{5}{|l|}{ Estrous stages (\% of cycle) } \\
\hline Diestrus & 24.2 & 26.7 & 26.7 & 25.8 \\
\hline Proestrus & 0.0 & 0.0 & 0.0 & 0.0 \\
\hline Estrus & 51.7 & 49.2 & 49.2 & 51.7 \\
\hline Metestrus & 24.2 & 24.2 & 24.2 & 22.5 \\
\hline
\end{tabular}

${ }^{a}$ Necropsy body weights and estrous cycle length data are presented as mean \pm standard error. Differences from the vehicle control group are not significant by Dunnett's test (body weight) or Dunn's test (estrous cycle length). By multivariate analysis of variance, dosed females do not differ significantly from the vehicle control females in the relative length of time spent in the estrous stages. 


\section{Appendix F. Chemical Characterization and Dose Formulation Studies}

\section{Table of Contents}

F.1. Procurement and Characterization.

F-2

F.2. Preparation and Analysis of Dose Formulations

\section{Tables}

Table F-1. Preparation and Storage of Dose Formulations in the Dermal Studies of

Sodium Thioglycolate

Table F-2. Results of Analyses of Dose Formulations Administered to Rats and Mice in the Two-week Dermal Studies of Sodium Thioglycolate

Table F-3. Results of Analyses of Dose Formulations Administered to Rats and Mice in the Three-month Dermal Studies of Sodium Thioglycolate

\section{Figures}

Figure F-1. Infrared Absorption Spectrum of Sodium Thioglycolate F-7

Figure F-2. Proton Nuclear Magnetic Resonance Spectrum of Sodium Thioglycolate F-8

Figure F-3. Carbon-13 Nuclear Magnetic Resonance Spectrum of Sodium Thioglycolate F-8 


\section{F.1. Procurement and Characterization}

\section{F.1.1. Sodium Thioglycolate}

Sodium thioglycolate was obtained by the analytical chemistry laboratory (Midwest Research Institute, Kansas City, MO) from Sigma Chemical Company (Columbus, OH) in one lot (88H1166) that was used in the 2-week and 3-month studies. Identity, purity, and stability analyses were conducted by the analytical chemistry laboratory. Reports on analyses performed in support of the sodium thioglycolate studies are on file at the National Institute of Environmental Health Sciences.

Lot $88 \mathrm{H} 1166$ of the chemical, a white powder, was identified as sodium thioglycolate by infrared and proton and carbon-13 nuclear magnetic resonance (NMR) spectroscopy. The infrared spectrum was consistent with a literature spectrum ${ }^{43}$ of sodium thioglycolate, and NMR spectra were consistent with the proposed structure of the test article. The infrared and NMR spectra are presented in Figure F-1, Figure F-2, and Figure F-3.

The purity of lot $88 \mathrm{H} 1166$ was determined by ion chromatography using a Dionex LC20 chromatograph (Dionex Corporation, Sunnyvale, CA) with conductivity detection, a Dionex IonPac ${ }^{\circledR}$ AS11-HC column $(25 \mathrm{~cm} \times 4 \mathrm{~mm}, 9 \mu \mathrm{m}$ particle size $)$, and a mobile phase of $17.5 \mathrm{mM}$ aqueous sodium hydroxide at an isocratic flow rate of $1.0 \mathrm{~mL} / \mathrm{minute}$. Purity assays indicated one major peak and three impurities with a combined area of approximately $1 \%$ relative to the total peak area. The overall purity of lot $88 \mathrm{H} 1166$ was determined to be approximately $99 \%$.

Stability studies of a different lot of the bulk chemical were performed by the analytical chemistry laboratory using the ion chromatography system previously described. These studies indicated that sodium thioglycolate was stable as a bulk chemical for 14 days when stored protected from light frozen $\left(-20^{\circ} \mathrm{C}\right)$, refrigerated $\left(5^{\circ} \mathrm{C}\right)$, and heated $\left(60^{\circ} \mathrm{C}\right)$ but not at ambient $\left(25^{\circ} \mathrm{C}\right)$ temperature. To ensure stability, the bulk chemical was stored under a headspace of inert gas at less than or equal to $-20^{\circ} \mathrm{C}$, protected from light, in amber glass bottles. The analytical chemistry laboratory reanalyzed the bulk chemical at the end of the 3-month study by ion chromatography using the system previously described. No degradation of the bulk chemical was detected.

\section{F.1.2. 95\% Ethanol}

95\% Ethanol, a clear liquid, was obtained from Pharmco Products, Inc. (Brookfield, CT), in two lots (P1107 and R8092); lot P1107 was used in the 2-week studies, and lot R8092 was used in the 3-month studies. The study laboratory (BioReliance Corporation, Rockville, MD) identified lot R8092 of the chemical as ethanol by infrared spectroscopy and determined the purities of both lots of the chemical using gas chromatography; no impurity peaks were noted.

\section{F.2. Preparation and Analysis of Dose Formulations}

The dose formulations were prepared on three separate days during the 2-week studies and approximately weekly during the 3-month studies by mixing sodium thioglycolate and the vehicle [95\% ethanol:deionized water (1:1)] to give the required concentration (Table F-1). The dose formulations were stored under an inert gas headspace at $2^{\circ}$ to $8^{\circ} \mathrm{C}$ in amber vials sealed 
with Teflon ${ }^{\circledR}$-lined septa and aluminum seals for up to 10 days. Fresh dosing bottles were opened each day.

Stability studies of a $3.1 \mathrm{mg} / \mathrm{mL}$ dose formulation of a different lot were performed by the analytical chemistry laboratory using ion chromatography by the system previously described. Stability was confirmed for at least 10 days for dose formulations stored at approximately $5^{\circ} \mathrm{C}$ in sealed amber vials and for at least 3 hours for dose formulations exposed to ambient temperature and light.

Periodic analyses of samples of the dose formulations of sodium thioglycolate were conducted by the analytical chemistry laboratory because ion chromatography was not available at the study laboratory. Samples of formulations were collected in amber glass vials under inert gas headspace and shipped on dry ice for overnight delivery to the analytical chemistry laboratory. Animal room samples were collected similarly following dosing on the last day of the use period. During the 2-week studies, the dose formulations were analyzed twice; nine of 10 dose formulations for rats and eight of 10 dose formulations for mice were within $10 \%$ of the target concentrations (Table F-2). For animal room samples analyzed, three of five for rats and three of five for mice were within $10 \%$ of the target concentrations. During the 3-month studies, the dose formulations were analyzed at the beginning, midpoint, and end of the studies; animal room samples of these dose formulations were also analyzed (Table F-3). Of the dose formulations analyzed, all 15 for rats and all 15 for mice were within $10 \%$ of the target concentrations; two of 15 animal room samples analyzed for rats and four of 15 animal room samples analyzed for mice were within $10 \%$ of the target concentrations. Declines in animal room sample concentrations of sodium thioglycolate were attributed to degradation during the additional time required for shipping and analyzing the samples at the end of the use period.

Table F-1. Preparation and Storage of Dose Formulations in the Dermal Studies of Sodium Thioglycolate

\begin{tabular}{ll}
\hline Two-week Studies & Three-month Studies \\
\hline Preparation
\end{tabular}

\section{Preparation}

The vehicle was prepared by combining equal volumes of $95 \%$ ethanol and deionized water. The dose formulations were prepared by dissolving a weighed amount of sodium thioglycolate in a measured volume of the vehicle. Magnetic stirring was used to ensure that the test article was completely dissolved. Dose formulations were prepared three times. Fresh dosing bottles were opened each day.

\section{Chemical Lot Number}

$88 \mathrm{H} 1166$

\section{Maximum Storage Time}

10 days
The vehicle was prepared by combining equal volumes of $95 \%$ ethanol and deionized water. The dose formulations were prepared by dissolving a weighed amount of sodium thioglycolate in a measured volume of the vehicle; brief sonication and magnetic stirring were used to ensure that the test article was completely dissolved. Dose formulations were prepared approximately weekly. Fresh dosing bottles were opened each day.

88H1166

10 days 


\begin{tabular}{|c|c|}
\hline Two-week Studies & Three-month Studies \\
\hline \multicolumn{2}{|l|}{ Storage Conditions } \\
\hline $\begin{array}{l}\text { Stored at } 2^{\circ} \text { to } 8^{\circ} \mathrm{C} \text { in amber vials sealed with Teflon }{ }^{\circledR} \text { - } \\
\text { lined septa and aluminum seals after purging the } \\
\text { headspace with inert gas }\end{array}$ & $\begin{array}{l}\text { Stored at } 2^{\circ} \text { to } 8^{\circ} \mathrm{C} \text { in amber vials sealed with Teflon }{ }^{\circledR} \\
\text { lined septa and aluminum seals after purging the } \\
\text { headspace with inert gas }\end{array}$ \\
\hline \multicolumn{2}{|l|}{ Study Laboratory } \\
\hline BioReliance Corporation (Rockville, MD) & BioReliance Corporation (Rockville, MD) \\
\hline
\end{tabular}

Table F-2. Results of Analyses of Dose Formulations Administered to Rats and Mice in the Twoweek Dermal Studies of Sodium Thioglycolate

\begin{tabular}{|c|c|c|c|c|}
\hline Date Prepared & Date Analyzed & $\begin{array}{c}\text { Target Concentration } \\
(\mathrm{mg} / \mathrm{mL})\end{array}$ & $\begin{array}{c}\text { Determined } \\
\text { Concentration }^{\mathrm{a}}(\mathrm{mg} / \mathrm{mL})\end{array}$ & $\begin{array}{c}\text { Difference from } \\
\text { Target }(\%)\end{array}$ \\
\hline \multicolumn{5}{|l|}{ Rats } \\
\hline \multirow[t]{5}{*}{ January 8, 2001} & January 10, 2001 & 22.5 & 23.9 & +6 \\
\hline & & 45 & 46.5 & +3 \\
\hline & & 90 & 92.7 & +3 \\
\hline & & 180 & 182.4 & +1 \\
\hline & & 360 & 377.5 & +5 \\
\hline \multirow[t]{10}{*}{ January 25, 2001} & February 7, 2001 & 22.5 & 23.3 & +4 \\
\hline & & 45 & 47.4 & +5 \\
\hline & & 90 & 98.1 & +9 \\
\hline & & 180 & 202.5 & +13 \\
\hline & & 360 & 395.2 & +10 \\
\hline & February $7,2001^{\mathrm{b}}$ & 22.5 & 21.2 & -6 \\
\hline & & 45 & 45.9 & +2 \\
\hline & & 90 & 96.9 & +8 \\
\hline & & 180 & 204.1 & +13 \\
\hline & & 360 & 405.7 & +13 \\
\hline \multicolumn{5}{|l|}{ Mice } \\
\hline \multirow[t]{5}{*}{ January 8, 2001} & January 10, 2001 & 11.25 & 11.46 & +2 \\
\hline & & 22.5 & 23.9 & +6 \\
\hline & & 45 & 46.5 & +3 \\
\hline & & 90 & 92.7 & +3 \\
\hline & & 180 & 182.4 & +1 \\
\hline \multirow[t]{4}{*}{ January 25, 2001} & February 7, 2001 & 11.25 & 10.03 & -11 \\
\hline & & 22.5 & 23.3 & +4 \\
\hline & & 45 & 47.4 & +5 \\
\hline & & 90 & 98.1 & +9 \\
\hline
\end{tabular}




\begin{tabular}{|c|c|c|c|c|}
\hline Date Prepared & Date Analyzed & $\begin{array}{c}\text { Target Concentration } \\
\qquad(\mathrm{mg} / \mathrm{mL})\end{array}$ & $\begin{array}{c}\text { Determined } \\
\text { Concentration }^{\mathrm{a}}(\mathrm{mg} / \mathrm{mL})\end{array}$ & $\begin{array}{l}\text { Difference from } \\
\text { Target }(\%)\end{array}$ \\
\hline & \multirow{6}{*}{ February $7,2001^{b}$} & 180 & 202.5 & +13 \\
\hline & & 11.25 & 9.34 & -17 \\
\hline & & 22.5 & 20.6 & -8 \\
\hline & & 45 & 41.3 & -8 \\
\hline & & 90 & 91.7 & +2 \\
\hline & & 180 & 202.6 & +13 \\
\hline
\end{tabular}

${ }^{\mathrm{a}}$ Results of duplicate analyses. For rats, dosing volume $=0.5 \mathrm{~mL} / \mathrm{kg} ; 22.5 \mathrm{mg} / \mathrm{mL}=11.25 \mathrm{mg} / \mathrm{kg}, 45 \mathrm{mg} / \mathrm{mL}=22.5 \mathrm{mg} / \mathrm{kg}$, $90 \mathrm{mg} / \mathrm{mL}=45 \mathrm{mg} / \mathrm{kg}, 180 \mathrm{mg} / \mathrm{mL}=90 \mathrm{mg} / \mathrm{kg}, 360 \mathrm{mg} / \mathrm{mL}=180 \mathrm{mg} / \mathrm{kg}$. For mice, dosing volume $=2 \mathrm{~mL} / \mathrm{kg}$;

$11.25 \mathrm{mg} / \mathrm{mL}=22.5 \mathrm{mg} / \mathrm{kg}, 22.5 \mathrm{mg} / \mathrm{mL}=45 \mathrm{mg} / \mathrm{kg}, 45 \mathrm{mg} / \mathrm{mL}=90 \mathrm{mg} / \mathrm{kg}, 90 \mathrm{mg} / \mathrm{mL}=180 \mathrm{mg} / \mathrm{kg}, 180 \mathrm{mg} / \mathrm{mL}=360 \mathrm{mg} / \mathrm{kg}$.

${ }^{\mathrm{b}}$ Animal room sample.

Table F-3. Results of Analyses of Dose Formulations Administered to Rats and Mice in the Three-month Dermal Studies of Sodium Thioglycolate

\begin{tabular}{|c|c|c|c|c|}
\hline Date Prepared & Date Analyzed & $\begin{array}{c}\text { Target } \\
\text { Concentration } \\
(\mathrm{mg} / \mathrm{mL})\end{array}$ & $\begin{array}{c}\text { Determined } \\
\text { Concentration } \\
(\mathbf{m g} / \mathbf{m L})\end{array}$ & $\begin{array}{l}\text { Difference from } \\
\text { Target }(\%)\end{array}$ \\
\hline \multicolumn{5}{|l|}{ Rats } \\
\hline \multirow{10}{*}{ December 9, 2002} & December 12, 2002 & 22.5 & 21.5 & -4 \\
\hline & & 45 & 44.0 & -2 \\
\hline & & 90 & 85.1 & -5 \\
\hline & & 180 & 178.0 & -1 \\
\hline & & 360 & 363.0 & +1 \\
\hline & December 20 and 23, 2002 ${ }^{\mathrm{b}}$ & 22.5 & $15.94^{\mathrm{c}}$ & -29 \\
\hline & & 45 & $36.4^{\mathrm{c}}$ & -19 \\
\hline & & 90 & 84.7 & -6 \\
\hline & & 180 & 165.8 & -8 \\
\hline & & 360 & 254.7 & -29 \\
\hline \multirow[t]{10}{*}{ January 27, 2003} & January 28, 2003 & 22.5 & $22.83^{\mathrm{c}}$ & +1 \\
\hline & & 45 & 44.65 & -1 \\
\hline & & 90 & 82.63 & -8 \\
\hline & & 180 & 161.7 & -10 \\
\hline & & 360 & 345.6 & -4 \\
\hline & February $7,2003^{b}$ & 22.5 & 10.02 & -55 \\
\hline & & 45 & 31.53 & -30 \\
\hline & & 90 & 64.03 & -29 \\
\hline & & 180 & 139.3 & -23 \\
\hline & & 360 & 258.2 & -28 \\
\hline March 11, 2003 & March 17, 2003 & 22.5 & 20.59 & -8 \\
\hline
\end{tabular}


Sodium Thioglycolate, NTP TOX 80

\begin{tabular}{|c|c|c|c|c|}
\hline Date Prepared & Date Analyzed & $\begin{array}{c}\text { Target } \\
\text { Concentration } \\
(\mathbf{m g} / \mathbf{m L})\end{array}$ & $\begin{array}{c}\text { Determined } \\
\text { Concentration }^{\mathrm{a}} \\
(\mathrm{mg} / \mathrm{mL})\end{array}$ & $\begin{array}{c}\text { Difference from } \\
\text { Target }(\%)\end{array}$ \\
\hline & \multirow{9}{*}{ March 24, 2003 } & 45 & 43.4 & -4 \\
\hline & & 90 & 87.1 & -3 \\
\hline & & 180 & 175.8 & -2 \\
\hline & & 360 & 324.2 & -10 \\
\hline & & 22.5 & 12.67 & -44 \\
\hline & & 45 & 34.8 & -23 \\
\hline & & 90 & 70.4 & -22 \\
\hline & & 180 & 129.8 & -28 \\
\hline & & 360 & 260.5 & -28 \\
\hline \multicolumn{5}{|l|}{ Mice } \\
\hline \multirow[t]{10}{*}{ December 9, 2002} & December 12, 2002 & 11.25 & 10.78 & -4 \\
\hline & & 22.5 & 21.5 & -4 \\
\hline & & 45 & 44.0 & -2 \\
\hline & & 90 & 85.1 & -5 \\
\hline & & 180 & 178.0 & -1 \\
\hline & December 20 and $23,2002^{\mathrm{b}}$ & 11.25 & $9.31^{\mathrm{c}}$ & -17 \\
\hline & & 22.5 & 21.14 & -6 \\
\hline & & 45 & 44.3 & -2 \\
\hline & & 90 & 90.3 & 0 \\
\hline & & 180 & 172.0 & -4 \\
\hline \multirow[t]{10}{*}{ January 27, 2003} & January 28, 2003 & 11.25 & $12.06^{\mathrm{c}}$ & +7 \\
\hline & & 22.5 & 22.83 & +1 \\
\hline & & 45 & 44.65 & -1 \\
\hline & & 90 & 82.63 & -8 \\
\hline & & 180 & 161.7 & -10 \\
\hline & February $7,2003^{b}$ & 11.25 & 5.22 & -54 \\
\hline & & 22.5 & 13.38 & -41 \\
\hline & & 45 & 30.86 & -31 \\
\hline & & 90 & 63.62 & -29 \\
\hline & & 180 & 150.9 & -16 \\
\hline \multirow[t]{5}{*}{ March 11, 2003} & March 17, 2003 & 11.25 & 10.45 & -7 \\
\hline & & 22.5 & 20.59 & -8 \\
\hline & & 45 & 43.4 & -4 \\
\hline & & 90 & 87.1 & -3 \\
\hline & & 180 & 175.8 & -2 \\
\hline
\end{tabular}


Sodium Thioglycolate, NTP TOX 80

\begin{tabular}{ccccc}
\hline Date Prepared & Date Analyzed & $\begin{array}{c}\text { Target } \\
\text { Concentration } \\
(\mathbf{m g} / \mathbf{m L})\end{array}$ & $\begin{array}{c}\text { Determined } \\
\text { Concentrationa } \\
(\mathbf{m g} / \mathbf{m L})\end{array}$ & $\begin{array}{c}\text { Difference from } \\
\text { Target }(\%)\end{array}$ \\
\hline March 24, 2003 & 11.25 & 3.12 & -72 \\
& 22.5 & 7.52 & -67 \\
& 45 & 23.4 & -48 \\
& 90 & 59.4 & -34 \\
& 180 & 135.3 & -25 \\
\hline
\end{tabular}

aResults of duplicate analyses. For rats, dosing volume $=0.5 \mathrm{~mL} / \mathrm{kg} ; 22.5 \mathrm{mg} / \mathrm{mL}=11.25 \mathrm{mg} / \mathrm{kg}, 45 \mathrm{mg} / \mathrm{mL}=22.5 \mathrm{mg} / \mathrm{kg}$, $90 \mathrm{mg} / \mathrm{mL}=45 \mathrm{mg} / \mathrm{kg}, 180 \mathrm{mg} / \mathrm{mL}=90 \mathrm{mg} / \mathrm{kg}, 360 \mathrm{mg} / \mathrm{mL}=180 \mathrm{mg} / \mathrm{kg}$. For mice, dosing volume $=2 \mathrm{~mL} / \mathrm{kg}$;

$11.25 \mathrm{mg} / \mathrm{mL}=22.5 \mathrm{mg} / \mathrm{kg}, 22.5 \mathrm{mg} / \mathrm{mL}=45 \mathrm{mg} / \mathrm{kg}, 45 \mathrm{mg} / \mathrm{mL}=90 \mathrm{mg} / \mathrm{kg}, 90 \mathrm{mg} / \mathrm{mL}=180 \mathrm{mg} / \mathrm{kg}, 180 \mathrm{mg} / \mathrm{mL}=360 \mathrm{mg} / \mathrm{kg}$.

bAnimal room samples.

${ }^{\mathrm{c}}$ Results of triplicate analyses.

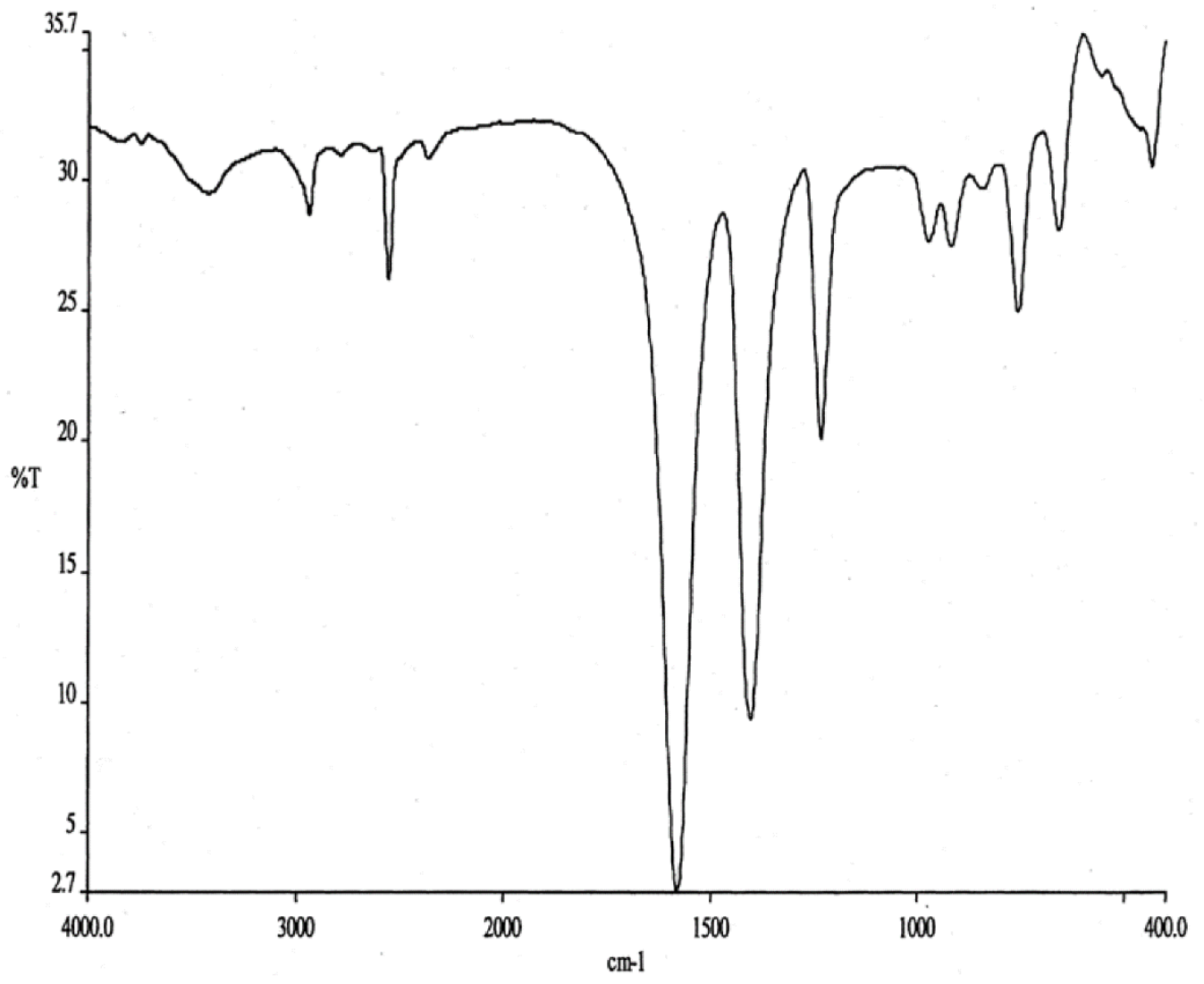

Figure F-1. Infrared Absorption Spectrum of Sodium Thioglycolate 
Sodium Thioglycolate, NTP TOX 80

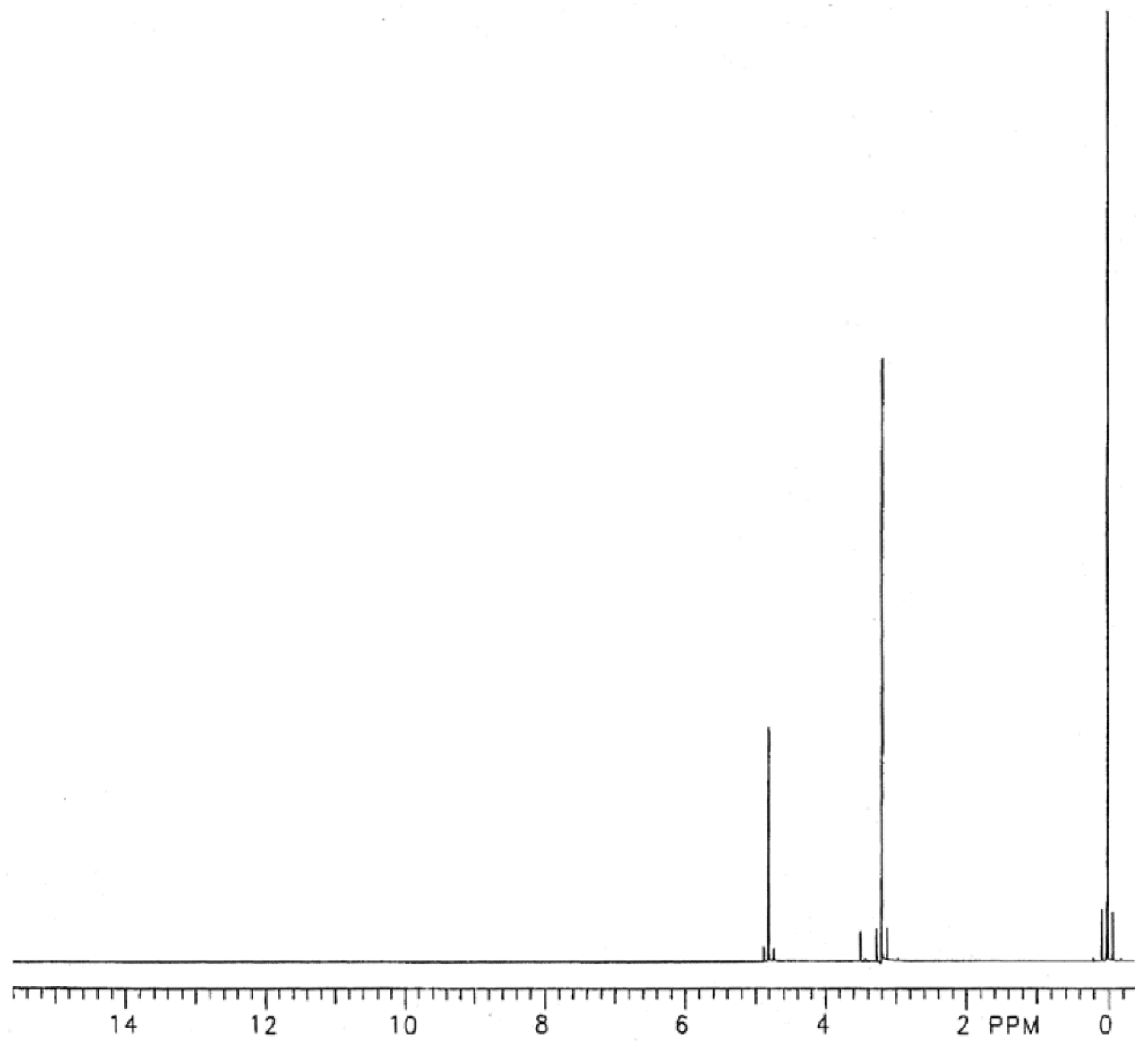

Figure F-2. Proton Nuclear Magnetic Resonance Spectrum of Sodium Thioglycolate

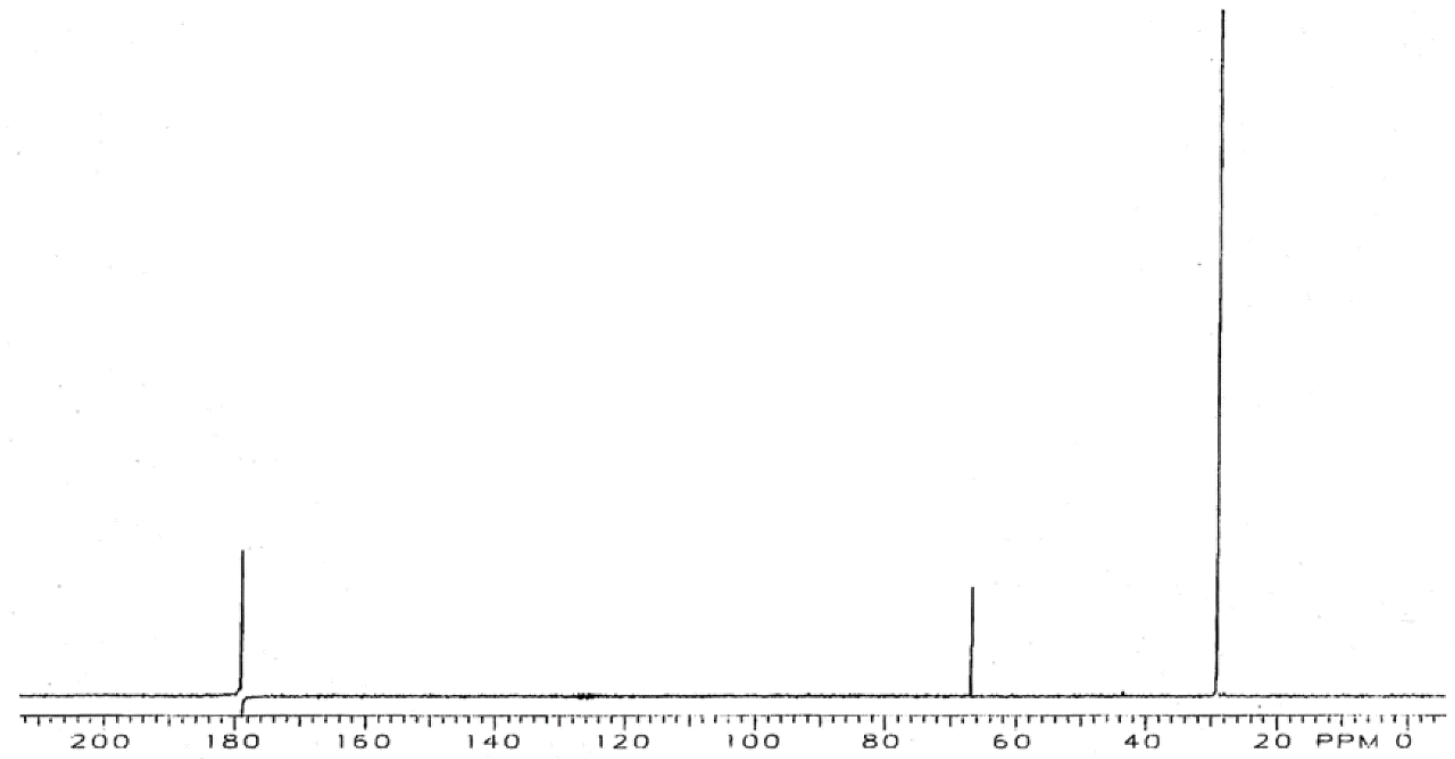

Figure F-3. Carbon-13 Nuclear Magnetic Resonance Spectrum of Sodium Thioglycolate 
Sodium Thioglycolate, NTP TOX 80

\section{Appendix G. Feed Consumption}

\section{Tables}

Table G-1. Feed Consumption for Male Rats in the Three-month Dermal Study of Sodium Thioglycolate ............................................................................. G-2

Table G-2. Feed Consumption for Female Rats in the Three-month Dermal Study of Sodium Thioglycolate G-3

Table G-3. Feed Consumption for Male Mice in the Three-month Dermal Study of Sodium Thioglycolate G-4

Table G-4. Feed Consumption for Female Mice in the Three-month Dermal Study of

Sodium Thioglycolate G-5 
Sodium Thioglycolate, NTP TOX 80

Table G-1. Feed Consumption for Male Rats in the Three-month Dermal Study of Sodium Thioglycolate $^{\mathrm{a}}$

\begin{tabular}{|c|c|c|c|c|c|c|}
\hline \multirow[b]{2}{*}{ Week } & \multicolumn{2}{|c|}{ Vehicle Control } & \multicolumn{2}{|c|}{$11.25 \mathrm{mg} / \mathrm{kg}$} & \multicolumn{2}{|c|}{$22.5 \mathrm{mg} / \mathrm{kg}$} \\
\hline & Feed (g/day) & N/M & Feed (g/day) & $\mathbf{N} / \mathbf{M}$ & Feed (g/day) & $\mathbf{N} / \mathbf{M}$ \\
\hline 2 & 16.9 & $10 / 10$ & 16.6 & $10 / 10$ & 15.7 & $10 / 10$ \\
\hline 3 & 17.8 & $10 / 10$ & 15.9 & $10 / 10$ & 17.6 & $10 / 10$ \\
\hline 4 & 19.3 & $10 / 10$ & 19.2 & $10 / 10$ & 19.7 & $10 / 10$ \\
\hline 5 & 20.5 & $10 / 10$ & 20.2 & $10 / 10$ & 20.6 & $10 / 10$ \\
\hline 6 & 25.3 & $10 / 20$ & 23.6 & $10 / 20$ & 24.0 & $10 / 20$ \\
\hline 7 & 28.4 & $10 / 20$ & 27.6 & $10 / 20$ & 28.6 & $10 / 20$ \\
\hline 8 & 24.3 & $10 / 20$ & 22.7 & $10 / 20$ & 22.9 & $10 / 20$ \\
\hline 9 & 27.2 & $10 / 20$ & 27.8 & $10 / 20$ & 27.5 & $10 / 20$ \\
\hline 10 & 26.2 & $10 / 20$ & 23.8 & $10 / 20$ & 25.0 & $10 / 20$ \\
\hline 11 & 26.3 & $10 / 20$ & 26.0 & $10 / 20$ & 29.4 & $10 / 20$ \\
\hline 12 & 24.9 & $10 / 20$ & 24.1 & $10 / 20$ & 26.5 & $10 / 20$ \\
\hline 13 & 27.5 & $10 / 20$ & 26.9 & $10 / 20$ & 28.2 & $10 / 20$ \\
\hline \multirow[t]{2}{*}{14} & 24.2 & $10 / 10$ & 22.4 & $10 / 10$ & 23.9 & $10 / 10$ \\
\hline & \multicolumn{2}{|c|}{45 mg/kg } & \multicolumn{2}{|c|}{$90 \mathrm{mg} / \mathrm{kg}$} & \multicolumn{2}{|c|}{$180 \mathrm{mg} / \mathrm{kg}$} \\
\hline 2 & 16.1 & $10 / 10$ & 14.9 & $10 / 10$ & 15.4 & $10 / 10$ \\
\hline 3 & 19.7 & $10 / 10$ & 18.3 & $10 / 10$ & 19.9 & $10 / 10$ \\
\hline 4 & 20.2 & $10 / 10$ & 19.1 & $10 / 10$ & 19.5 & $10 / 10$ \\
\hline 5 & 21.2 & $10 / 10$ & 20.4 & $10 / 10$ & 21.5 & $10 / 10$ \\
\hline 6 & 24.1 & $10 / 20$ & 23.6 & $10 / 20$ & 23.6 & $10 / 20$ \\
\hline 7 & 30.7 & $10 / 20$ & 27.5 & $10 / 20$ & 27.8 & $10 / 20$ \\
\hline 8 & 25.6 & $10 / 20$ & 22.8 & $10 / 20$ & 23.0 & $10 / 20$ \\
\hline 9 & 27.0 & $10 / 20$ & 25.2 & $10 / 20$ & 26.1 & $10 / 20$ \\
\hline 10 & 26.1 & $10 / 20$ & 22.5 & $10 / 20$ & 24.3 & $10 / 20$ \\
\hline 11 & 28.9 & $10 / 20$ & 25.4 & $10 / 20$ & 24.8 & $10 / 20$ \\
\hline 12 & 24.8 & $10 / 20$ & 24.5 & $10 / 20$ & 24.6 & $10 / 20$ \\
\hline 13 & 30.9 & $10 / 20$ & 26.1 & $10 / 20$ & 26.1 & $10 / 20$ \\
\hline 14 & 25.5 & $10 / 10$ & 21.2 & $10 / 10$ & 23.0 & $10 / 10$ \\
\hline
\end{tabular}

${ }^{\mathrm{a}}$ Feed $=$ average feed consumption in grams/animal per day; $\mathrm{N}=$ number of animals; $\mathrm{M}=$ number of feed consumption measurements per week. 
Sodium Thioglycolate, NTP TOX 80

Table G-2. Feed Consumption for Female Rats in the Three-month Dermal Study of Sodium Thioglycolate $^{\mathrm{a}}$

\begin{tabular}{|c|c|c|c|c|c|c|}
\hline \multirow[b]{2}{*}{ Week } & \multicolumn{2}{|c|}{ Vehicle Control } & \multicolumn{2}{|c|}{$11.25 \mathrm{mg} / \mathrm{kg}$} & \multicolumn{2}{|c|}{$22.5 \mathrm{mg} / \mathrm{kg}$} \\
\hline & Feed (g/day) & $\mathbf{N} / \mathbf{M}$ & Feed (g/day) & N/M & Feed (g/day) & $\mathbf{N} / \mathbf{M}$ \\
\hline 2 & 13.8 & $10 / 10$ & 13.2 & $10 / 10$ & 13.9 & $10 / 10$ \\
\hline 3 & 15.4 & $10 / 10$ & 16.4 & $10 / 10$ & 17.1 & $10 / 10$ \\
\hline 4 & 16.0 & $10 / 10$ & 16.3 & $10 / 10$ & 16.4 & $10 / 10$ \\
\hline 5 & 14.9 & $10 / 10$ & 14.9 & $10 / 10$ & 14.9 & $10 / 10$ \\
\hline 6 & 16.7 & $10 / 10$ & 18.3 & $10 / 10$ & 17.6 & $10 / 10$ \\
\hline 7 & 15.8 & $10 / 10$ & 15.3 & $10 / 10$ & 17.4 & $10 / 10$ \\
\hline 8 & 18.9 & $10 / 10$ & 19.8 & $10 / 10$ & 20.5 & $10 / 10$ \\
\hline 9 & 16.4 & $10 / 10$ & 18.5 & $10 / 10$ & 20.0 & $10 / 10$ \\
\hline 10 & 17.0 & $10 / 10$ & 18.6 & $10 / 10$ & 20.6 & $10 / 10$ \\
\hline 11 & 14.9 & $10 / 10$ & 16.6 & $10 / 10$ & 18.5 & $10 / 10$ \\
\hline 12 & 19.2 & $10 / 10$ & 17.8 & $10 / 10$ & 18.1 & $10 / 10$ \\
\hline 13 & 15.6 & $10 / 10$ & 16.5 & $10 / 10$ & 18.5 & $10 / 10$ \\
\hline \multirow[t]{2}{*}{14} & 16.0 & $10 / 10$ & 16.1 & $10 / 10$ & 18.2 & $10 / 10$ \\
\hline & \multicolumn{2}{|c|}{$45 \mathrm{mg} / \mathrm{kg}$} & \multicolumn{2}{|c|}{$90 \mathrm{mg} / \mathrm{kg}$} & \multicolumn{2}{|c|}{$180 \mathrm{mg} / \mathrm{kg}$} \\
\hline 2 & 13.6 & $10 / 10$ & 13.1 & $10 / 10$ & 12.1 & $10 / 10$ \\
\hline 3 & 16.3 & $10 / 10$ & 16.9 & $10 / 10$ & 15.9 & $10 / 10$ \\
\hline 4 & 16.2 & $10 / 10$ & 15.3 & $10 / 10$ & 14.0 & $10 / 10$ \\
\hline 5 & 16.0 & $10 / 10$ & 14.7 & $10 / 10$ & 14.5 & $10 / 10$ \\
\hline 6 & 19.1 & $10 / 10$ & 16.0 & $10 / 10$ & 18.3 & $10 / 10$ \\
\hline 7 & 18.7 & $10 / 10$ & 16.8 & $10 / 10$ & 15.9 & $10 / 10$ \\
\hline 8 & 21.2 & $10 / 10$ & 15.9 & $10 / 10$ & 15.2 & $10 / 10$ \\
\hline 9 & 19.1 & $10 / 10$ & 17.0 & $10 / 10$ & 16.1 & $10 / 10$ \\
\hline 10 & 18.7 & $10 / 10$ & 17.4 & $10 / 10$ & 17.5 & $10 / 10$ \\
\hline 11 & 17.7 & $10 / 10$ & 15.9 & $10 / 10$ & 16.5 & $10 / 10$ \\
\hline 12 & 17.7 & $10 / 10$ & 16.6 & $10 / 10$ & 18.5 & $10 / 10$ \\
\hline 13 & 20.4 & $10 / 10$ & 18.9 & $10 / 10$ & 20.1 & $10 / 10$ \\
\hline 14 & 17.6 & $10 / 10$ & 16.6 & $10 / 10$ & 16.3 & $10 / 10$ \\
\hline
\end{tabular}

aFeed = average feed consumption in grams/animal per day; $\mathrm{N}=$ number of animals; $\mathrm{M}=$ number of feed consumption measurements per week. 
Sodium Thioglycolate, NTP TOX 80

Table G-3. Feed Consumption for Male Mice in the Three-month Dermal Study of Sodium Thioglycolate $^{\mathrm{a}}$

\begin{tabular}{|c|c|c|c|c|c|c|}
\hline \multirow[b]{2}{*}{ Week } & \multicolumn{2}{|c|}{ Vehicle Control } & \multicolumn{2}{|c|}{$22.5 \mathrm{mg} / \mathrm{kg}$} & \multicolumn{2}{|c|}{$45 \mathrm{mg} / \mathrm{kg}$} \\
\hline & Feed (g/day) & $\mathbf{N} / \mathbf{M}$ & Feed (g/day) & $\mathbf{N} / \mathbf{M}$ & Feed (g/day) & $\mathbf{N} / \mathbf{M}$ \\
\hline 2 & 5.7 & $10 / 10$ & 5.5 & $10 / 10$ & 5.4 & $10 / 10$ \\
\hline 3 & 6.6 & $10 / 10$ & 7.0 & $10 / 10$ & 6.4 & $10 / 10$ \\
\hline 4 & 6.9 & $10 / 10$ & 6.6 & $10 / 10$ & 7.0 & $10 / 10$ \\
\hline 5 & 6.3 & $10 / 10$ & 6.6 & $10 / 10$ & 7.0 & $10 / 10$ \\
\hline 6 & 6.7 & $10 / 10$ & 6.4 & $10 / 10$ & 7.0 & $10 / 10$ \\
\hline 7 & 6.1 & $10 / 10$ & 6.7 & $10 / 10$ & 6.3 & $10 / 10$ \\
\hline 8 & 5.8 & $10 / 10$ & 6.5 & $10 / 10$ & 6.2 & $10 / 10$ \\
\hline 9 & 6.6 & $10 / 10$ & 6.4 & $10 / 10$ & 6.9 & $10 / 10$ \\
\hline 10 & 7.0 & $10 / 10$ & 6.6 & $10 / 10$ & 7.4 & $10 / 10$ \\
\hline 11 & 6.2 & $10 / 10$ & 6.2 & $10 / 10$ & 7.2 & $10 / 10$ \\
\hline 12 & 6.4 & $10 / 10$ & 6.2 & $10 / 10$ & 6.3 & $10 / 10$ \\
\hline 13 & 6.5 & $10 / 10$ & 6.4 & $10 / 10$ & 6.2 & $9 / 9$ \\
\hline \multirow[t]{2}{*}{14} & 6.3 & $10 / 10$ & 6.4 & $10 / 10$ & 6.4 & $10 / 10$ \\
\hline & \multicolumn{2}{|c|}{$90 \mathrm{mg} / \mathrm{kg}$} & \multicolumn{2}{|c|}{$180 \mathrm{mg} / \mathrm{kg}$} & \multicolumn{2}{|c|}{$360 \mathrm{mg} / \mathrm{kg}$} \\
\hline 2 & 5.4 & $10 / 10$ & 6.1 & $10 / 10$ & 6.3 & $10 / 10$ \\
\hline 3 & 6.6 & $10 / 10$ & 6.2 & $10 / 10$ & 7.0 & $10 / 10$ \\
\hline 4 & 6.3 & $10 / 10$ & 6.3 & $10 / 10$ & 6.8 & $10 / 10$ \\
\hline 5 & 5.7 & $10 / 10$ & 6.4 & $10 / 10$ & 6.9 & $10 / 10$ \\
\hline 6 & 6.2 & $9 / 9$ & 6.4 & $10 / 10$ & 7.8 & $10 / 10$ \\
\hline 7 & 6.0 & $10 / 10$ & 6.4 & $10 / 10$ & 6.1 & $10 / 10$ \\
\hline 8 & 5.8 & $10 / 10$ & 6.4 & $10 / 10$ & 7.1 & $10 / 10$ \\
\hline 9 & 6.4 & $10 / 10$ & 6.6 & $10 / 10$ & 6.8 & $10 / 10$ \\
\hline 10 & 6.2 & $10 / 10$ & 6.6 & $10 / 10$ & 7.1 & $10 / 10$ \\
\hline 11 & 6.4 & $10 / 10$ & 6.1 & $10 / 10$ & 7.8 & $10 / 10$ \\
\hline 12 & 5.8 & $10 / 10$ & 6.9 & $10 / 10$ & 7.1 & $10 / 10$ \\
\hline 13 & 7.0 & $10 / 10$ & 6.7 & $10 / 10$ & 7.3 & $10 / 10$ \\
\hline 14 & 6.0 & $10 / 10$ & 6.5 & $10 / 10$ & 7.1 & $10 / 10$ \\
\hline
\end{tabular}

${ }^{\mathrm{a}}$ Feed = average feed consumption in grams/animal per day; $\mathrm{N}=$ number of animals; $\mathrm{M}=$ number of feed consumption measurements per week. 
Sodium Thioglycolate, NTP TOX 80

Table G-4. Feed Consumption for Female Mice in the Three-month Dermal Study of Sodium Thioglycolate $^{\mathrm{a}}$

\begin{tabular}{|c|c|c|c|c|c|c|}
\hline \multirow[b]{2}{*}{ Week } & \multicolumn{2}{|c|}{ Vehicle Control } & \multicolumn{2}{|c|}{$22.5 \mathrm{mg} / \mathrm{kg}$} & \multicolumn{2}{|c|}{$45 \mathrm{mg} / \mathrm{kg}$} \\
\hline & Feed (g/day) & $\mathbf{N} / \mathbf{M}$ & Feed (g/day) & $\mathbf{N} / \mathbf{M}$ & Feed (g/day) & $\mathbf{N} / \mathbf{M}$ \\
\hline 2 & 5.6 & $10 / 10$ & 6.1 & $10 / 10$ & 5.8 & $10 / 10$ \\
\hline 3 & 7.7 & $10 / 10$ & 6.6 & $10 / 10$ & 7.2 & $10 / 10$ \\
\hline 4 & 6.7 & $10 / 10$ & 6.3 & $10 / 10$ & 7.0 & $10 / 10$ \\
\hline 5 & 7.0 & $10 / 10$ & 7.6 & $10 / 10$ & 6.2 & $10 / 10$ \\
\hline 6 & 6.5 & $10 / 10$ & 6.0 & $10 / 10$ & 6.6 & $9 / 9$ \\
\hline 7 & 6.1 & $10 / 10$ & 6.3 & $10 / 10$ & 5.9 & $10 / 10$ \\
\hline 8 & 6.4 & $10 / 10$ & 5.7 & $10 / 10$ & 6.9 & $10 / 10$ \\
\hline 9 & 7.0 & $10 / 10$ & 6.2 & $10 / 10$ & 6.9 & $10 / 10$ \\
\hline 10 & 6.8 & $10 / 10$ & 6.8 & $10 / 10$ & 6.7 & $10 / 10$ \\
\hline 11 & 7.0 & $10 / 10$ & 6.7 & $10 / 10$ & 6.9 & $10 / 10$ \\
\hline 12 & 6.7 & $10 / 10$ & 6.5 & $10 / 10$ & 6.5 & $10 / 10$ \\
\hline 13 & 7.2 & $10 / 10$ & 7.3 & $10 / 10$ & 8.0 & $10 / 10$ \\
\hline \multirow[t]{2}{*}{14} & 7.0 & $10 / 10$ & 7.4 & $10 / 10$ & 7.2 & $10 / 10$ \\
\hline & \multicolumn{2}{|c|}{$90 \mathrm{mg} / \mathrm{kg}$} & \multicolumn{2}{|c|}{$180 \mathrm{mg} / \mathrm{kg}$} & \multicolumn{2}{|c|}{$360 \mathrm{mg} / \mathrm{kg}$} \\
\hline 2 & 5.6 & $10 / 10$ & 5.1 & $10 / 10$ & 6.3 & $10 / 10$ \\
\hline 3 & 6.8 & $10 / 10$ & 6.1 & $10 / 10$ & 6.6 & $10 / 10$ \\
\hline 4 & 6.7 & $10 / 10$ & 7.0 & $10 / 10$ & 7.1 & $10 / 10$ \\
\hline 5 & 6.7 & $10 / 10$ & 7.2 & $10 / 10$ & 6.9 & $10 / 10$ \\
\hline 6 & 6.8 & $10 / 10$ & 6.8 & $10 / 10$ & 6.9 & $10 / 10$ \\
\hline 7 & 7.0 & $10 / 10$ & 6.3 & $10 / 10$ & 6.6 & $10 / 10$ \\
\hline 8 & 6.3 & $10 / 10$ & 7.6 & $10 / 10$ & 6.6 & $10 / 10$ \\
\hline 9 & 7.8 & $10 / 10$ & 7.4 & $10 / 10$ & 7.0 & $10 / 10$ \\
\hline 10 & 6.5 & $10 / 10$ & 7.0 & $10 / 10$ & 7.0 & $10 / 10$ \\
\hline 11 & 7.0 & $10 / 10$ & 7.3 & $10 / 10$ & 7.4 & $10 / 10$ \\
\hline 12 & 6.9 & $10 / 10$ & 7.0 & $10 / 10$ & 7.5 & $10 / 10$ \\
\hline 13 & 7.8 & $10 / 10$ & 7.7 & $10 / 10$ & 7.7 & $10 / 10$ \\
\hline 14 & 7.2 & $10 / 10$ & 7.7 & $10 / 10$ & 7.7 & $10 / 10$ \\
\hline
\end{tabular}

${ }^{\mathrm{a}}$ Feed $=$ average feed consumption in grams/animal per day; $\mathrm{N}=$ number of animals; $\mathrm{M}=$ number of feed consumption measurements per week. 


\section{Appendix H. Ingredients, Nutrient Composition, and Contaminant Levels in NTP-2000 Rat and Mouse Ration}

\section{Tables}

Table H-1. Ingredients of NTP-2000 Rat and Mouse Ration

$\mathrm{H}-2$

Table H-2. Vitamins and Minerals in NTP-2000 Rat and Mouse Ration $\mathrm{H}-3$

Table H-3. Nutrient Composition of NTP-2000 Rat and Mouse Ration $\mathrm{H}-4$

Table H-4. Contaminant Levels in NTP-2000 Rat and Mouse Ration $\mathrm{H}-5$ 
Sodium Thioglycolate, NTP TOX 80

Table H-1. Ingredients of NTP-2000 Rat and Mouse Ration

\begin{tabular}{lc}
\hline \multicolumn{1}{c}{ Ingredients } & Percent by Weight \\
\hline Ground hard winter wheat & 22.26 \\
Ground \#2 yellow shelled corn & 22.18 \\
Wheat middlings & 15.0 \\
Oat hulls & 8.5 \\
Alfalfa meal (dehydrated, 17\% protein) & 7.5 \\
Purified cellulose & 5.5 \\
Soybean meal (49\% protein) & 5.0 \\
Fish meal (60\% protein) & 4.0 \\
Corn oil (without preservatives) & 3.0 \\
Soy oil (without preservatives) & 3.0 \\
Dried brewer's yeast & 1.0 \\
Calcium carbonate (USP) & 0.9 \\
Vitamin premix & \\
Mineral premix & \\
Calcium phosphate, dibasic (USP) & 0.5 \\
Sodium chloride & 0.5 \\
Choline chloride (70\% choline) & 0.4 \\
Methionine & 0.3 \\
\hline Wh me & 0.26 \\
\hline
\end{tabular}

${ }^{\mathrm{a}}$ Wheat middlings as carrier.

${ }^{\mathrm{b}}$ Calcium carbonate as carrier. 
Sodium Thioglycolate, NTP TOX 80

Table H-2. Vitamins and Minerals in NTP-2000 Rat and Mouse Ration ${ }^{\text {a }}$

\begin{tabular}{lcl}
\hline & Amount & \multicolumn{1}{c}{ Source } \\
\hline Vitamins & & \\
$\mathrm{A}$ & $4,000 \mathrm{IU}$ & Stabilized vitamin A palmitate or acetate \\
$\mathrm{D}$ & $1,000 \mathrm{IU}$ & D-activated animal sterol \\
$\mathrm{K}$ & $1.0 \mathrm{mg}$ & Menadione sodium bisulfite complex \\
$\alpha$-Tocopheryl acetate & $100 \mathrm{IU}$ & - \\
Niacin & $23 \mathrm{mg}$ & - \\
Folic acid & $1.1 \mathrm{mg}$ & - \\
$d$-Pantothenic acid & $10 \mathrm{mg}$ & \\
Riboflavin & $3.3 \mathrm{mg}$ & $d$-Calcium pantothenate \\
Thiamine & $4 \mathrm{mg}$ & - \\
B 12 & $52 \mu \mathrm{g}$ & Thiamine mononitrate \\
Pyridoxine & $6.3 \mathrm{mg}$ & Pyridoxine hydrochloride \\
Biotin & $0.2 \mathrm{mg}$ & $d$-Biotin \\
\hline Minerals & & \\
Magnesium & $514 \mathrm{mg}$ & Magnesium oxide \\
Iron & $35 \mathrm{mg}$ & Iron sulfate \\
Zinc & $12 \mathrm{mg}$ & Zinc oxide \\
Manganese & $10 \mathrm{mg}$ & Manganese oxide \\
Copper & $2.0 \mathrm{mg}$ & Copper sulfate \\
Iodine & $0.2 \mathrm{mg}$ & Calcium iodate \\
Chromium & $0.2 \mathrm{mg}$ & Chromium acetate \\
aPer kg of finished product. &
\end{tabular}


Sodium Thioglycolate, NTP TOX 80

Table H-3. Nutrient Composition of NTP-2000 Rat and Mouse Ration

\begin{tabular}{|c|c|c|c|}
\hline Nutrient & $\begin{array}{c}\text { Mean } \pm \text { Standard } \\
\text { Deviation }\end{array}$ & Range & Number of Samples \\
\hline Protein (\% by weight) & 15.3 & - & 1 \\
\hline Crude fat ( $\%$ by weight) & 8.5 & - & 1 \\
\hline Crude fiber ( $\%$ by weight) & 10.0 & - & 1 \\
\hline Ash (\% by weight) & 5.6 & - & 1 \\
\hline \multicolumn{4}{|c|}{ Amino Acids (\% of total diet) } \\
\hline Arginine & $0.783 \pm 0.070$ & $0.670-0.970$ & 22 \\
\hline Cystine & $0.220 \pm 0.024$ & $0.150-0.250$ & 22 \\
\hline Glycine & $0.701 \pm 0.041$ & $0.620-0.800$ & 22 \\
\hline Histidine & $0.352 \pm 0.077$ & $0.270-0.680$ & 22 \\
\hline Isoleucine & $0.546 \pm 0.044$ & $0.430-0.660$ & 22 \\
\hline Leucine & $1.095 \pm 0.067$ & $0.960-1.240$ & 22 \\
\hline Lysine & $0.711 \pm 0.114$ & $0.310-0.860$ & 22 \\
\hline Methionine & $0.409 \pm 0.046$ & $0.260-0.490$ & 22 \\
\hline Phenylalanine & $0.627 \pm 0.040$ & $0.540-0.720$ & 22 \\
\hline Threonine & $0.505 \pm 0.043$ & $0.430-0.610$ & 22 \\
\hline Tryptophan & $0.150 \pm 0.028$ & $0.110-0.200$ & 22 \\
\hline Tyrosine & $0.401 \pm 0.061$ & $0.280-0.540$ & 22 \\
\hline Valine & $0.665 \pm 0.043$ & $0.550-0.730$ & 22 \\
\hline \multicolumn{4}{|c|}{ Essential Fatty Acids (\% of total diet) } \\
\hline Linoleic & $3.95 \pm 0.259$ & $3.49-4.55$ & 22 \\
\hline Linolenic & $0.30 \pm 0.032$ & $0.21-0.35$ & 22 \\
\hline \multicolumn{4}{|l|}{ Vitamins } \\
\hline Vitamin A (IU/kg) & 7,400 & - & 1 \\
\hline Vitamin D (IU/kg) & $1,000^{\mathrm{a}}$ & - & - \\
\hline$\alpha$-Tocopherol (ppm) & $80.6 \pm 22.03$ & $27.0-124.0$ & 22 \\
\hline Thiamine (ppm) $)^{\mathrm{b}}$ & 7.3 & - & 1 \\
\hline Riboflavin (ppm) & $7.6 \pm 2.89$ & $4.20-17.50$ & 22 \\
\hline Niacin (ppm) & $78.9 \pm 9.08$ & $66.4-98.2$ & 22 \\
\hline Pantothenic acid (ppm) & $26.88 \pm 12.63$ & $17.4-81.0$ & 22 \\
\hline Pyridoxine $(\mathrm{ppm})^{\mathrm{b}}$ & $9.54 \pm 2.00$ & $6.44-13.7$ & 22 \\
\hline Folic acid (ppm) & $1.62 \pm 0.48$ & $1.15-3.27$ & 22 \\
\hline Biotin (ppm) & $0.32 \pm 0.10$ & $0.2-0.704$ & 22 \\
\hline Vitamin $B_{12}(p p b)$ & $53.6 \pm 39.6$ & $18.3-174.0$ & 22 \\
\hline Choline (ppm) $)^{\mathrm{b}}$ & $2,846 \pm 484$ & $1,820-3,790$ & 22 \\
\hline
\end{tabular}


Sodium Thioglycolate, NTP TOX 80

\begin{tabular}{lccc}
\hline \multicolumn{1}{c}{ Nutrient } & $\begin{array}{c}\text { Mean } \pm \text { Standard } \\
\text { Deviation }\end{array}$ & Range & Number of Samples \\
\hline Minerals & 1.07 & - & 1 \\
Calcium (\%) & 0.608 & - & 1 \\
Phosphorus (\%) & $0.666 \pm 0.030$ & $0.626-0.733$ & 22 \\
Potassium (\%) & $0.386 \pm 0.039$ & $0.300-0.474$ & 22 \\
Chloride (\%) & $0.189 \pm 0.016$ & $0.160-0.222$ & 22 \\
Sodium (\%) & $0.216 \pm 0.062$ & $0.185-0.49$ & 22 \\
Magnesium (\%) & $0.170 \pm 0.029$ & $0.116-0.209$ & 22 \\
Sulfur (\%) & $185 \pm 39.2$ & $135-311$ & 22 \\
Iron (ppm) & $51.4 \pm 10.28$ & $21.0-73.1$ & 22 \\
Manganese (ppm) & $53.4 \pm 8.46$ & $43.3-78.5$ & 22 \\
Zinc (ppm) & $7.01 \pm 2.56$ & $3.21-16.30$ & 22 \\
Copper (ppm) & $0.503 \pm 0.206$ & $0.158-0.972$ & 21 \\
Iodine (ppm) & $0.694 \pm 0.275$ & $0.330-1.380$ & 20 \\
Chromium (ppm) & $0.26 \pm 0.164$ & $0.098-0.864$ & \\
Cobalt (ppm) & &
\end{tabular}

aFrom formulation.

${ }^{\mathrm{b}}$ As hydrochloride (thiamine and pyridoxine) or chloride (choline).

Table H-4. Contaminant Levels in NTP-2000 Rat and Mouse Ration ${ }^{\mathrm{a}}$

\begin{tabular}{|c|c|c|}
\hline & Mean $^{b}$ & Number of Samples \\
\hline \multicolumn{3}{|l|}{ Contaminants } \\
\hline Arsenic (ppm) & 0.50 & 1 \\
\hline Cadmium (ppm) & 0.04 & 1 \\
\hline Lead (ppm) & 0.07 & 1 \\
\hline Mercury (ppm) & $<0.02$ & 1 \\
\hline Selenium (ppm) & 0.20 & 1 \\
\hline Aflatoxins (ppb) & $<5.00$ & 1 \\
\hline Nitrate nitrogen $(\mathrm{ppm})^{\mathrm{c}}$ & 18.8 & 1 \\
\hline Nitrite nitrogen $(\mathrm{ppm})^{\mathrm{c}}$ & $<0.61$ & 1 \\
\hline BHA $(p p m)^{d}$ & $<1.0$ & 1 \\
\hline BHT (ppm) $)^{d}$ & $<1.0$ & 1 \\
\hline Aerobic plate count (CFU/g) & 50 & 1 \\
\hline Coliform (MPN/g) & 3.0 & 1 \\
\hline Escherichia coli (MPN/g) & $<10$ & 1 \\
\hline Salmonella (MPN/g) & Negative & 1 \\
\hline Total nitrosamines $(\mathrm{ppb})^{\mathrm{e}}$ & 5.8 & 1 \\
\hline$N$-Nitrosodimethylamine $(\mathrm{ppb})^{\mathrm{e}}$ & 3.3 & 1 \\
\hline$N$-Nitrosopyrrolidine $(\mathrm{ppb})^{\mathrm{e}}$ & 2.5 & 1 \\
\hline
\end{tabular}


Sodium Thioglycolate, NTP TOX 80

\begin{tabular}{|c|c|c|}
\hline & Mean $^{b}$ & Number of Samples \\
\hline \multicolumn{3}{|l|}{ Pesticides (ppm) } \\
\hline$\alpha-\mathrm{BHC}$ & $<0.01$ & 1 \\
\hline$\beta$-BHC & $<0.02$ & 1 \\
\hline$\gamma-\mathrm{BHC}$ & $<0.01$ & 1 \\
\hline$\delta$-BHC & $<0.01$ & 1 \\
\hline Heptachlor & $<0.01$ & 1 \\
\hline Aldrin & $<0.01$ & 1 \\
\hline Heptachlor epoxide & $<0.01$ & 1 \\
\hline DDE & $<0.01$ & 1 \\
\hline DDD & $<0.01$ & 1 \\
\hline DDT & $<0.01$ & 1 \\
\hline $\mathrm{HCB}$ & $<0.01$ & 1 \\
\hline Mirex & $<0.01$ & 1 \\
\hline Methoxychlor & $<0.05$ & 1 \\
\hline Dieldrin & $<0.01$ & 1 \\
\hline Endrin & $<0.01$ & 1 \\
\hline Telodrin & $<0.01$ & 1 \\
\hline Chlordane & $<0.05$ & 1 \\
\hline Toxaphene & $<0.10$ & 1 \\
\hline Estimated PCBs & $<0.20$ & 1 \\
\hline Ronnel & $<0.01$ & 1 \\
\hline Ethion & $<0.02$ & 1 \\
\hline Trithion & $<0.05$ & 1 \\
\hline Diazinon & $<0.10$ & 1 \\
\hline Methyl chlorpyrifos & 0.039 & 1 \\
\hline Methyl parathion & $<0.02$ & 1 \\
\hline Ethyl parathion & $<0.02$ & 1 \\
\hline Malathion & 1.01 & 1 \\
\hline Endosulfan I & $<0.01$ & 1 \\
\hline Endosulfan II & $<0.01$ & 1 \\
\hline Endosulfan sulfate & $<0.03$ & 1 \\
\hline
\end{tabular}

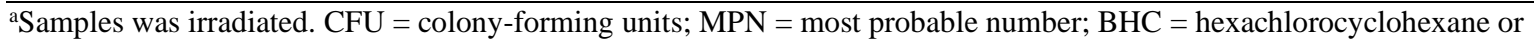
benzene hexachloride.

${ }^{\mathrm{b}}$ For values less than the limit of detection, the detection limit is given.

'Sources of contamination: alfalfa, grains, and fish meal.

${ }^{\mathrm{d}}$ Sources of contamination: soy oil and fish meal.

eAll values were corrected for percent recovery. 


\section{Appendix I. Sentinel Animal Program \\ Table of Contents}

I.1. Methods

$\mathrm{I}-2$

I.2. Results

Tables

Table I-1. Laboratory Methods and Agents Tested for in the Sentinel Animal Program............. I-2 


\section{l.1. Methods}

Rodents used in the National Toxicology Program are produced in optimally clean facilities to eliminate potential pathogens that may affect study results. The Sentinel Animal Program is part of the periodic monitoring of animal health that occurs during the toxicologic evaluation of test compounds. Under this program, the disease state of the rodents is monitored via sera or feces from extra (sentinel) animals in the study rooms. The sentinel animals and the study animals are subject to identical environmental conditions. Furthermore, the sentinel animals come from the same production source and weanling groups as the animals used for the studies of test compounds.

Blood samples were collected from each animal and allowed to clot, and the serum was separated. Additionally, fecal samples were collected and tested for Helicobacter species. All samples were processed appropriately and evaluated for the presence of pathogens. The laboratory methods and agents for which testing was performed are tabulated below; the times at which samples were collected during the studies are also listed.

Table I-1. Laboratory Methods and Agents Tested for in the Sentinel Animal Program

\begin{tabular}{ll}
\hline \multicolumn{1}{c}{ Method and Test } & Time of Collection \\
\hline Rats & \\
3-month study & \\
ELISA & \\
PVM (pneumonia virus of mice) & Study termination \\
RCV/SDA (rat coronavirus/sialodacryoadenitis virus) & Study termination \\
Sendai & Study termination \\
Immunofluorescence Assay & \\
Parvovirus & Study termination \\
Mice & \\
3-month study & \\
ELISA & \\
Ectromelia virus & \\
EDIM (epizootic diarrhea of infant mice) & Study termination \\
GDVII (mouse encephalomyelitis virus) & Study termination \\
LCM (lymphocytic choriomeningitis virus) & Study termination \\
Mouse adenoma virus-FL & Study termination \\
MHV (mouse hepatitis virus) & Study termination \\
PVM & Study termination \\
Reovirus & Study termination \\
Sendai & Study termination \\
Immunofluorescence Assay & Study termination \\
Parvovirus & \\
\hline & Study termination \\
\hline
\end{tabular}


Sodium Thioglycolate, NTP TOX 80

\section{I.2. Results}

All test results were negative. 


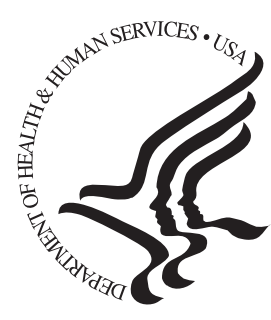

\section{National Toxicology Program}

\section{NTP Central Data Management, MD EC-03}

National Institute of Environmental Health Sciences

P.O. Box 12233

Research Triangle Park, NC 27709

http://ntp.niehs.nih.gov 